NBER WORKING PAPER SERIES

\title{
EMERGING EQUITY MARKET \\ VOLATILITY
}

Geert Bekaert

Campbell R. Harvey

Working Paper 5307

\author{
NATIONAL BUREAU OF ECONOMIC RESEARCH \\ 1050 Massachusetts Avenue \\ Cambridge, MA 02138 \\ October 1995
}

We have benefitted from the comments of Tim Bollerslev, Rene Garcia, Will Goetzmann, Jianping Mei, Steve Ross and seminar participants at New York University, Northwestern University, Yale University, Georgetown University, the CIRANO-C.D.R.E. Conference on Stochastic Volatility in Montreal, the American Finance Association Meetings in Washington, and the European Finance Association Meetings in Milan. Harvey's research was supported by the Batterymarch Fellowship. Bekaert acknowledges the financial support of an NSF grant and the Financial Services Research Initiative and the Bass Faculty Fellowship of the Graduate School of Business at Stanford. We thank Arman Glodjo, Akhtar Siddique, Guojun Wu, and Nese Yildiz for research assistance. We especially appreciate the research assistance of Magnus Dahlquist. This paper is part of NBER's research program in Asset Pricing. Any opinions expressed are those of the authors and not those of the National Bureau of Economic Research.

() 1995 by Geert Bekaert and Campbell R. Harvey. All rights reserved. Short sections of text, not to exceed two paragraphs, may be quoted without explicit permission provided that full credit, including () notice, is given to the source. 


\title{
EMERGING EQUITY MARKET \\ VOLATILITY
}

\begin{abstract}
Returns in emerging capital markets are very different from returns in developed markets. While most previous research has focused on average returns, we analyze the volatility of the returns in emerging equity markets. We characterize the time-series of volatility in emerging markets and explore the distributional foundations of the variance process. Of particular interest is evidence of asymmetries in volatility and the evolution of the variance process after periods of capital market reform. We shed indirect light on the question of capital market integration by exploring the changing influence of world factors on the volatility in emerging markets. Finally, we investigate the cross-section of volatility. We use measures such as asset concentration, market capitalization to GDP, size of the trade sector, cross-sectional volatility of individual securities within each country, turnover, foreign exchange variability and national credit ratings to characterize why volatility is different across emerging markets.
\end{abstract}

Geert Bekaert

Graduate School of Business

Stanford University

Stanford, CA 94305-5015

and NBER
Campbell R. Harvey

Fuqua School of Business

Duke University

Durham, NC 27708

and NBER 


\section{Introduction}

It is now well known that emerging market equities have vastly different characteristics than equities from developed capital markets. There are at least four distinguishing features of emerging market returns: average returns are higher, correlations with developed market returns are low, returns are more predictable and volatility is higher. Our research focusses on this last feature.

We provide a detailed analysis of equity market volatility in emerging capital markets. We attempt to answer the question of why volatility is so different across emerging equity markets. This is an important question. In segmented capital markets, risk premiums may be directly related to the volatility of equity returns in the particular market. Higher volatility implies higher capital costs. Higher volatility may also increase the value of the "option to wait," hence delaying investments. Our research helps understand the forces that shape both the time-series variation and cross-sectional dispersion of volatility in twenty emerging equity markets.

We begin by analyzing the time-series of volatility. Given the evidence of nonnormalities in emerging market returns presented in Harvey (1995a), it is unlikely that the standard implementation of the Engle (1982) and Bollerslev (1986) autoregressive conditional heteroskedasticity (ARCH) models is fruitful. We address this problem by estimating models using the student $t$ distribution which allows for fatter tails in the return distributions. We also fit models using the semi-parametric ARCH (SPARCH) model developed in Engle and GonzalezRivera (1991) and Gray (1994). The SPARCH model is explicitly designed to account for leptokurtosis and skewness. This model is particularly appropriate for emerging market returns which exhibit both types of nonnormalities.

We are careful to link previous research on the conditional means of the emerging market returns to the conditional variance specifications. Since Harvey (1995a), Bekaert (1995) and Bekaert and Harvey (1995) show that emerging market equity returns are predictable, our variance specifications allow for time- 
varying conditional means.

Much of the focus of our paper is on the common world factors that drive the time-series of volatility. This part of our research is related to the work of Schwert $(1989 a, b)$ who attempts to explain the time-variation in U.S. market volatility with macroeconomic and microstructural factors. In our analysis, we measure the part of national volatility that is determined by world factors and the part determined by local market effects. We also investigate whether this proportion changes through time. We argue that the increasing influence of world factors on volatility in some countries is consistent with increased market integration. This analysis is related to the time-varying market integration parameter that is proposed in Bekaert and Harvey (1995).

In addition to tracing the influence of world factors on market volatility, we investigate whether capital market liberalization policies affect volatility. The evidence, in Kim and Singal (1994), based on average volatilities, suggests that volatility may increase. Our methodology allows us to reexamine this issue in the context of time-varying means and variances. As is clear from Bekaert, Garcia and Harvey (1995a), insight on this issue is of great importance for policy makers in developing markets whom may be weighing the costs and benefits of various liberalization initiatives.

To control for other factors affecting volatility, we extend our analysis to the cross-section of volatility. This allows us to explore the question: Why is volatility different in different markets? We investigate whether the volatility is related to the number of stocks in the national index, asset concentration and the crosssectional volatility of the individual stocks within each country's index. We also examine whether volatility is related to variables capturing financial and economic integration such as market capitalization to GDP, exports plus imports to GDP and country credit risk ratings. Finally, following Schwert (1989a,b), we examine variables capturing macroeconomic volatility.

The paper is organized as follows. The second section presents the distributional characteristics of the emerging market data. The results of estimating time-series volatility models are presented in the third section. This section also 
includes an analysis of asymmetric volatility effects. The fourth section decomposes volatility into the parts determined by world and local factors. In the fifth section, we present an analysis of the cross-sectional patterns in volatility and detail how capital market reforms affect volatility. Some concluding remarks are offered in the final section.

\section{Data and summary statistics}

\subsection{Sources and preliminary analysis}

Data are available for 20 emerging markets from the International Finance Corporation (IFC) of the World Bank. Summary statistics are presented in Table 1 for the period 1976.01 to 1992.12. U.S. dollar returns are displayed. The statistics include the average (annualized) arithmetic return, annualized standard deviation and the first order autocorrelation. Each country's return is based on a valueweighted portfolio of securities that trade in that market. The number of stocks included in the country indices ranges from 16 to 77 . Stocks are selected for inclusion based on liquidity (how often they trade and the volume of trading) and size (market value). The industrial composition of the index is also important. That is, if there are two securities with approximately the same size and liquidity, the security which makes the index better reflect the industrial composition of the local market may be chosen. All of the indices reflect total returns: dividends and capital gains. The IFC indices are detailed and compared to the better known Morgan Stanley Capital International (MSCI) indices for developed markets in Bekaert and Harvey (1995) and Harvey (1995a)

The mean U.S. dollar returns for the emerging markets range from $68 \%$ (Argentina) to $-12 \%$ (Indonesia whose sample only begins in January 1990). This sharply contrasts with the range of average returns in the developed markets. For example, Bekaert (1995) and Harvey (1993) show that no developed country has an average arithmetic return that exceeds $25 \%$ over the same time period. In the IFC emerging sample, 8 countries (Argentina, Chile, Colombia, Philippines, Portugal, Taiwan, Turkey and Venezuela) have returns that average above $25 \%$. 
As mentioned earlier, the emerging market returns are characterized by high volatility. Volatility ranges from $18 \%$ (Jordan) to $104 \%$ (Argentina). In contrast, the MSCI countries have a range of volatility between $15 \%$ and $33 \%$. There are 12 emerging countries with volatility higher than $33 \%$ (Argentina, Brazil, Chile, Greece, Mexico, Nigeria, Philippines, Portugal, Taiwan, Turkey, Venezuela, and Zimbabwe). Three additional countries have volatility greater than $30 \%$ (Colombia, Indonesia, and Korea). Both the range and the magnitude of the volatilities is much greater than found in developed markets. Using the same sample, Harvey (1993) finds that volatility in developed markets ranges from $15 \%$ (U.S.) to $33 \%$ (Hong Kong) with an equally-weighted average volatility of $23 \%$.

The autocorrelation measures the persistence (or predictability) of the market returns based on past market returns. This persistence could be driven by market imperfections, such as infrequent trading of the component securities, or by some fundamental forces, such as predictable changes in sensitivities to world risk factors. In the MSCI sample, there are only five countries with first-order autocorrelation that exceeds $10 \%$. In the emerging countries, there are 12 countries with autocorrelations greater than $10 \%$. Indeed, there are eight countries with autocorrelations above 20\% (Colombia, Indonesia, Mexico, Pakistan, Philippines, Portugal, Turkey, and Venezuela). Although the sample is shorter for some of these countries and the standard errors of the autocorrelations are higher, the evidence suggests that the returns in many of the emerging markets are predictable based on past information.

In focussing on these emerging equity markets, a natural concern arises regarding potential survivorship biases. Harvey (1995a) shows that the pre-1981 data is 'backtracked' by the IFC. That is, firms where chosen for inclusion in nine countries in 1981, and the series were filled back to 1976. However, his analysis shows little difference between the 1976-80 and the later data. More fundamentally, one could argue that the sample countries are the countries that 'emerged.' That is, the countries that did not perform well economically over the sample, were not likely to make it into the IFC emerging markets index. While this is a valid argument $_{;}$it is also true for any stock index (like the S\&P 500). In contrast with 
standard market indices, the sample of countries that we look at includes countries that have not done particularly well in economic performance (like Nigeria and Zimbabwe).

\subsection{Distributional characteristics}

Evidence that many of the emerging market returns depart from normality is also presented in table 1 . If the data are normally distributed, then the coefficients of skewness and excess kurtosis should be equal to zero. Richardson and Smith (1993) and Harvey (1995a) test normality of equity returns based on Hansen's (1982) generalized method of moments (GMM). The following system of equations is estimated for each asset $i$ :

$$
\begin{aligned}
& e_{1 i t}=r_{i t}-\mu_{i} \\
& e_{2 i t}=\left(r_{i t}-\mu_{i}\right)^{2}-\mathcal{V}_{i} \\
& e_{3 i t}=\left[\left(r_{i t}-\mu_{i}\right)^{3}\right] / \mathcal{V}_{i}^{3 / 2}-s k \\
& e_{4 i t}=\left[\left(r_{i t}-\mu_{i}\right)^{4}\right] / \mathcal{V}_{i}^{2}-3-x k u
\end{aligned}
$$

where $\mu$ is the mean, $\mathcal{V}$ is the variance, $s k$ is the skewness, $x k u$ is the excess kurtosis, $\boldsymbol{e}_{t}=\left\{e_{1 i t} e_{2 i t} e_{3 i t} e_{4 i t}\right\}^{\prime}$ represents the disturbances and $E\left[\boldsymbol{e}_{t}\right]=\mathbf{0}$. There are four orthogonality conditions and four parameters which implies the model is exactly identified. The null hypothesis that the coefficients of skewness and excess kurtosis are zero is tested with a Wald test. ${ }^{1}$

The null hypothesis of unconditional normality can be rejected at the $5 \%$ level in 15 of the 20 emerging markets when measured in U.S. dollars. These results are consistent with those reported in Harvey (1995a) and Claessens, Dasgupta and Glen (1994). In contrast, Harvey (1995a) fails to reject unconditional normality in the three largest developed markets, the U.S., Japan and the U.K.

1 Richardson and Smith (1993) present this general framework. However, our weighting matrix is based on the spectral density at frequency zero with an optimal bandwidth which follows Andrews (1991). An alternative approach, presented in Harvey (1995a), is to set $s k$ and $x k u$ equal to zero and estimate an overidentified system. This results in a $\chi^{2}$ test with two degrees of freedom. 


\section{Characterizing variance in emerging markets}

\subsection{Conditional variance estimation with nonnormal returns}

We examine the following $\operatorname{GARCH}(1,1)$ model of volatility:

$$
\begin{aligned}
r_{i, t} & =\mathbf{X}_{i, t-1}^{\prime} \delta_{i}+\epsilon_{i, t} \\
\epsilon_{i, t} & =\sigma_{i, t} z_{i, t} \\
\sigma_{i, t}^{2} & =w_{i}+\alpha_{i} \sigma_{i, t-1}^{2}+\beta_{i} \epsilon_{i, t-1}^{2}
\end{aligned}
$$

where $r_{i, t}$ represents the arithmetic return ${ }^{2}$ on the national equity index of country $i$ in U.S. dollars, $\mathbf{X}_{i, t-1}$ represents a set of local information variables that affect the conditional mean, $\sigma_{i, t}^{2}$ is the conditional variance and $z_{i, t}$ are the standardized residuals formed by dividing the residuals, $\epsilon_{i, t}$ by the volatility, $\sigma_{i, t}$.

This model of volatility is univariate in the sense that other countries' volatilities do not influence the predictions and there is no attempt to model the covariance dynamics. We think of this model as the "fully segmented" model. Consistent with this view, we allow local information variables, $\mathbf{X}_{i, t-1}$, rather than global information variables, to affect the conditional mean returns. In particular, local information variables include: a constant, the lagged equity return, the lagged exchange rate change, the lagged dividend yield and lagged market capitalization to GDP. In section four, we introduce a world factor model which allows for global influences on both the mean and volatility.

There are three different distributional assumptions in the general model:

$$
\begin{array}{rll}
\text { Model I : } & z_{i, t} \mid \boldsymbol{I}_{t-1} \sim N(0,1) \\
\text { Model II : } & z_{i, t} \mid \boldsymbol{I}_{t-1} \sim t_{\nu}(0,1) \\
\text { Model III : } & z_{i, t} \mid \boldsymbol{I}_{t-1} \sim \begin{cases}N\left(\mu_{i 1}, \sigma_{i 1}\right), & \text { w.p. } p_{i} ; \\
N\left(\mu_{i 2}, \sigma_{i 2}\right), & \text { w.p. }\left(1-p_{i}\right) .\end{cases}
\end{array}
$$

where $\boldsymbol{I}_{t-1}$ is the information set available to investors at $t-1$. The first model is the standard normal formulation. The second model introduces a t distribution

${ }^{2}$ In order to provide a direct link with the asset pricing models presented in section 4 , we use arithmetic rather than geometric returns. We have estimated the modet for several countries using log returns yielding similar results to the ones obtained using arithmetic returns. 
with $\nu$ degrees of freedom. This is a one-parameter extension of model I. While able to accommodate fat tails, the assumed distribution is symmetric in model II.

The third model is designed to capture both fat tails and skewness (which quite a few of the emerging markets exhibit). Model III is a parsimonious version of semi-parametric ARCH [see Engle and Gonzalez-Rivera (1991) and Gray (1995a,b)]. Since in ARCH models, the conditional mean of the standardized residuals is equal to zero and the conditional variance is equal to one, additional constraints need to be imposed:

$$
\begin{aligned}
& \mu_{2}=\frac{-p \mu_{1}}{1-p} \\
& \sigma_{2}=\sqrt{\frac{1-p \sigma_{1}^{2}-\left(p \mu_{1}+(1-p) \mu_{2}^{2}\right)}{1-p}}
\end{aligned}
$$

Hence, this model is a three parameter extension of the standard model.

We are also interested in asymmetric variance effects. Black (1976), Christie (1982), Nelson (1991) and Glosten, Jagannathan and Runkle (1993) pursue the intuition that variance is higher when market returns are negative. One explanation is that the leverage of the firm increases with negative returns inducing a higher volatility. It is most likely that these leverage effects will be found in firms which already employ considerable debt financing. While we do not have data on the debt-equity ratios of the individual firms in the emerging markets, many of the countries themselves are highly levered. Hence, it seems important to allow for the possibility of asymmetries in the variance function.

To accommodate asymmetries, we modify the third equation in (2) with:

$$
\sigma_{i, t}^{2}=w_{i}+\alpha_{i} \sigma_{i, t-1}^{2}+\beta_{i} \epsilon_{i, t-1}^{2}+\gamma_{i} S_{i, t} \epsilon_{i, t-1}^{2}
$$

where $S_{i, t}$ is an indicator variable:

$$
S_{i, t}= \begin{cases}1, & \text { if } \epsilon_{i, t-1}<0 \\ 0, & \text { if } \epsilon_{i, t-1} \geq 0\end{cases}
$$

This is the Glosten, Jagannathan and Runkle (1993) and Zakoian (1990) model. ${ }^{3}$ If negative returns increase volatility, $\gamma_{i}>0$. This model allows us to test for asymmetries in the volatility of emerging equity returns.

${ }^{3}$ Engle and $\mathrm{Ng}$ (1993) found this model to perform better than other asymmetric models in Monte Carlo experiments. 


\subsection{Results}

A detailed analysis of the estimation of the univariate, segmented models is contained in Appendix A. We will briefly summarize these results. Table 2 summarizes the final volatility model chosen for each country. The selection criteria are based on the model diagnostics, parameter values and a visual examination of the fitted variances. ${ }^{4}$ If a number of models are similar, the most general model is chosen. In most cases, the choice of model was straight forward. However, with five countries, Indonesia, Jordan, Nigeria, Taiwan and Turkey, the choices were more difficult.

Our diagnostics are generalized method of moments based tests of the correct specification of the conditional mean, conditional variance and first four unconditional moments of the standardized residuals $\left(z_{i, t}\right)$. Consequently, these tests are quite demanding. Overall, the tests reveal evidence against the null hypothesis for almost all countries. Clearly, the GARCH models have difficulty fitting the highly volatile and nonnormal returns.

In general, the asymmetric GARCH provides an improvement in fit for most of the countries in our sample. Surprisingly, negative return innovations appear to decrease volatility in most countries, i.e. $\gamma_{i}$ is estimated to be negative. This is the opposite to what would be predicted based on the leverage hypothesis. A potential explanation derives from survivorship bias. ${ }^{5}$ The markets in our sample, with a few exceptions, are the ones that have emerged as successful stock markets. For markets to survive, volatility ought to decrease (at least some of the times) when markets are hit with negative shocks. This potentially explains the negative relation between volatility and returns shocks.

Finally, our tests reveal that for some countries, the conditional mean specification may not be adequate. The tests reveal that there is significant serial

4 In this estimation, we constrained $\alpha+\beta \leq 1$, even when asymmetric effects were allowed for. We reestimated all models for which this constraint was binding relaxing the constraint. Although $\alpha+\beta>1$ means covariance stationarity is violated, the process may still be strictly stationary. Our cross-sectional analysis uses the estimates where the constraint is not imposed.

5 We thank Steve Ross for this suggested interpretation. 
correlation in the standardized residuals in a number of countries.

While some estimations seem ill-behaved or are rejected, it is remarkable that the different models yield quite similar volatility behavior over time. Although we believe that the simple model in (2) captures an important part of the timevariation in conditional variances, the specification tests indicate that we may be missing some interesting dynamics. In particular, the assumption of having only local variables and shocks affecting conditional means and variances may be too restrictive.

\section{World versus local factors in volatility}

\subsection{Model specification}

In integrated world capital markets, shocks to the world market return affect all countries who have nonzero covariances with the world market. Bekaert and Harvey (1995) develop a model of the conditional mean return in emerging markets which allows for time-varying influences of both local and world factors. We apply the same type of intuition to our variance model. That is, as a market becomes more integrated both the conditional mean and the variance should be more influenced by world factors.

The following model allows for world and local influences in both the conditional means and variances. First, consider a model that describes world market returns and variances:

$$
\begin{aligned}
r_{w, t} & =\delta_{w}^{\prime} \mathbf{X}_{t-1}+\epsilon_{w, t} \\
\sigma_{w, t}^{2} & =c_{w}+\alpha_{w} \sigma_{w, t-1}^{2}+\beta_{w} \epsilon_{w, t-1}^{2}
\end{aligned}
$$

where $\mathbf{X}_{t-1}$ represents a set of world information variables which include: a constant, the world market dividend yield in excess of the 30-day Eurodollar rate, the default spread (Moody's Baa minus Aaa bond yields), the change in the term structure spread (U.S. 10-year bond yield minus 3-month U.S. bill), and the change in the 30-day Eurodollar rate. These variables are designed to capture fluctuations 
in expectations of the world business cycle. All of these information variables are lagged.

Following Bekaert and Harvey (1995), we allow the mean return in country $i$ to be a function of both world and local information:

$$
r_{i, t}=\theta_{i, t-1} \kappa_{i} \delta_{w}^{\prime} \mathbf{X}_{t-1}+\left(1-\theta_{i, t-1}\right)\left(\delta_{i}^{\prime} \mathbf{X}_{i, t-1}\right)+\epsilon_{i, t}
$$

where $\mathbf{X}_{i, t-1}$ represents the local information variables: a constant, the equity return, the exchange rate change, and the dividend yield, all of which are lagged. The influence of world and local information on the emerging market's expected return is allowed to change through time. ${ }^{6}$ The parameter, $\theta_{i, t-1}$, represents the importance of the world information variables. We restrict:

$$
\theta_{i, t-1}=\frac{\left(\lambda_{i}^{\prime} \mathbf{X}_{i, t-1}^{*}\right)^{2}}{1+\left(\lambda_{i}^{\prime} \mathbf{X}_{i, t-1}^{*}\right)^{2}}
$$

to fall in the range $[0,1]$. We consider a number of variables for $\mathbf{X}_{i, t-1}^{*}$ which might proxy for the degree of integration. When capital markets open up to foreign investment, the change of the marginal investor typically results in an increase in market capitalization to GDP. Finally, we consider the size of the trade sector (exports plus imports divided by GDP). International trade may enhance the cross-country correlation of consumption and business-cycles which, in turn, might lead to prices of risk and/or risk exposures moving together - even when capital markets are segmented. Note that the quadratic relation in (8) implies that the relation between $\mathbf{X}_{i, t-1}^{*}$ and $\theta_{i, t-1}$ need not be monotonic over the sample. This is useful when market capitalization increases because of local factors, for example, the introduction of a private pension plan. ${ }^{7}$

We allow the shocks to the local returns to be driven by both world and local shocks:

$$
\epsilon_{i, t}=\xi_{i} \psi_{i, t-1} \epsilon_{w, t}+e_{i, t}
$$

${ }^{6}$ The evidence in Garcia and Ghysels (1994) suggests that if expected returns in emerging markets are conditioned exclusively on world information variables, there is evidence of structural instability in linear models.

7 We experimented with logistic functions but found estimation to be much better behaved with quadratic functions. 
where $\xi_{i}$ is a scale parameter and $\psi_{i, t-1}$ represents the importance of the world shock which is also restricted to fall in the $[0,1]$ range.

$$
\psi_{i, t-1}=\frac{\left(\boldsymbol{\zeta}_{i}^{\prime} \mathbf{X}_{i, t-1}^{*}\right)^{2}}{1+\left(\boldsymbol{\zeta}_{i}^{\prime} \mathbf{X}_{i, t-1}^{*}\right)^{2}}
$$

As with $\theta_{i, t-1}, \psi_{i, t-1}$ is time varying and a function of local information which proxies for the degree of integration.

We impose additional restrictions:

$$
\begin{aligned}
& \text { (a) } E\left[e_{i, t} e_{i, j} \mid \mathbf{I}_{t-1}\right]=0 \quad \forall i \neq j \\
& \text { (b) } E\left[e_{i, t} \epsilon_{w, t} \mid \mathbf{I}_{t-1}\right]=0 \quad \forall i \\
& \text { (c) } E\left[e_{i, t}^{2} \mid \mathbf{I}_{t-1}\right]=\left(\sigma_{i, t}^{\ell}\right)^{2}=c_{i}+\alpha_{i}\left(\sigma_{i, t-1}^{\ell}\right)^{2}+\beta_{i} e_{i, t-1}^{2} .
\end{aligned}
$$

This model implies:

$$
E\left[\epsilon_{i, t}^{2} \mid \mathbf{I}_{t-1}\right]=\sigma_{i, t}^{2}=\xi_{i}^{2} \psi_{i, t-1}^{2} \sigma_{w, t}^{2}+\left(\sigma_{i, t}^{\ell}\right)^{2}
$$

and

$$
E\left[\epsilon_{i, t} \epsilon_{w, t} \mid \mathbf{I}_{t-1}\right]=\xi_{i} \psi_{i, t-1} \sigma_{w, t}^{2}=\sigma_{i w, t}
$$

This model is related to, but different from, the factor ARCH models of Engle, Ng and Rothchild (1990, 1992), King, Sentana and Wadhwani (1994) and Diebold and Nerlove (1989). In these models, a world factor is allowed to influence volatility at a constant rate. In the special case where $\theta_{i, t-1}=\psi_{i, t-1}=1$ for all $t$, the variance model is similar to the Engle, $\mathrm{Ng}$ and Rothchild model. If $\theta_{t-1}=1$ and $\delta_{w} \boldsymbol{X}_{t-1}$ is the world market premium, then the $\kappa_{i}$ coefficient in the conditional mean specification can be interpreted as the constant factor loading in a world capital asset pricing model. These factor models also imply the restriction $\kappa_{i}=\xi_{i}$. Below we will perform tests of $\kappa_{i}=\xi_{i}$ and $\theta_{i, t-1}=\psi_{i, t-1}$ both jointly and separately.

Unlike our previous models, this specification allows for both local and world influences in the mean and the variance. Importantly, the influence, in both cases, is allowed to change through time as a function of local variables which contain 
information regarding the country's degree of financial and economic integration with world economic markets.

The covariance dynamics of our model have two important implications. First, the covariance with the world market return is positively related to the degree of market integration. Second, the covariance with the world return increases in times of high world market volatility. As such, our results contribute to the literature on international stock market linkages. ${ }^{8}$

The two stylized facts often noted in this literature are that the process of globalization and deregulation has increased the correlations between stock markets over time and that the correlation between markets rises in periods when the volatility of markets is large (for example, around the October 1987 crash). The empirical evidence, particularly on the first fact, is mixed, however. For example, although Longin and Solnik (1994) document an upward trend in international correlations, King, Sentana and Wadhwani (1994) argue that the increase in correlations may be transitory and related to the October 1987 crash.

The world market correlation in our model is given by:

$$
\rho_{i t}=\xi_{i} \psi_{i, t-1} \frac{\sigma_{w, t}}{\sigma_{i, t}} .
$$

Hence, correlations increase when markets become more integrated or when world market volatility is high relative to local volatility. The latter mechanism is the only one present in the model of King, Sentana and Wadhwani (1994) to induce higher correlations between markets. A trend in the correlations can only arise when the factors in their model exhibit integrated GARCH behavior. Below we will graph the conditional correlations implied by the model. We will also investigate their behavior post-crash and post-capital market liberalization relative to the full sample.

Nevertheless, the assumptions in (11) are quite restrictive. Any misspecification will also result in misspecification of the covariance term. For example,

${ }^{8}$ See, King and Wadhwani (1990), Longin and Solnik (1994) and King, Sentana and Wadhwani (1994). Erb, Harvey and Viskanta (1994) show that correlations are higher in down markets and during recessions. 
as long as $\xi_{i}$ is positive, the covariance with the world return can never become negative. Therefore, we estimate a more general covariance model:

$$
\sigma_{i w, t}=k_{i}+f_{i} \psi_{i, t-1} \sigma_{w, t}^{2}+g_{i}\left(\sigma_{i, t}^{\ell}\right)^{2}
$$

where $f_{i} \neq \xi_{i}$. We refer to this model as the "extended model." If our representation is true, we should find:

$$
\begin{aligned}
k_{i} & =0 \\
f_{i} & =\xi_{i} \\
g_{i} & =0 .
\end{aligned}
$$

These restrictions are testable.

One additional diagnostic of the model involves its implications for the correlations between emerging markets. Since we have 20 different markets in our sample, joint estimation for all countries is computationally infeasible. As a result, we concentrate our attention on bivariate models. Our model implies:

$$
\begin{aligned}
E\left[u_{t} \mid \mathbf{I}_{t-1}\right] & =0 \\
\text { with } u_{t} & =\epsilon_{i, t} \epsilon_{j, t}-\xi_{i} \xi_{j} \psi_{i, t-1} \psi_{j, t-1} \sigma_{w, t}^{2}
\end{aligned}
$$

and note that the correlation coefficient is

$$
\rho_{i j, t}=\frac{\xi_{i} \xi_{j} \psi_{i, t-1} \psi_{j, t-1} \sigma_{w, t}^{2}}{\sigma_{i, t}^{2} \sigma_{j, t}^{2}} .
$$

It is well known that cross correlations between emerging markets are small. Our model may help us understand why the correlations are small. The correlations between markets are directly linked to their degree of integration in world capital markets.

Finally, we examine the proportion of local variance accounted for by world factors. The following variance ratio is computed:

$$
V R_{i, t}=\frac{\xi_{i}^{2} \psi_{i, t-1}^{2} \sigma_{w, t}^{2}}{\sigma_{i, t}^{2}} \in[0,1] .
$$

Using the definition in (13), we can equivalently write:

$$
V R_{i, t}=\frac{\xi_{i} \psi_{i, t-1} \sigma_{i w, t}}{\sigma_{i, t}^{2}}
$$


The variance ratio can be decomposed into three pieces:

$$
\underbrace{\xi_{i} \psi_{i, t-1}}_{\text {Degree of integration }} \underbrace{\frac{\sigma_{i w, t}}{\sigma_{i, t} \sigma_{w, t}}}_{\text {Correlation }} \underbrace{\frac{\sigma_{w, t}}{\sigma_{i, t}}}_{\text {Volatility ratio }} .
$$

$V R_{i, t}$ gives an indication of the proportion of the conditional variance that cannot be accounted for by the fully segmented model from section 3 . We will also examine the time-variation in $V R_{i, t}$ post-crash and post-liberalization.

\subsection{Estimation and specification tests}

We estimate (6) using maximum likelihood assuming normal innovations. These parameter estimates are then held fixed in the actual maximum likelihood estimation of the bivariate model. We report White (1982) standard errors that are robust to misspecification of the distribution of the error terms. However, we do not correct for the sampling error of the world market model parameters in the first-stage estimation. This approach yields consistent but not necessarily efficient estimates.

Important assumptions underlying our bivariate country by country estimation are: (1) The density of $r_{w, t}$ conditional on $I_{t-1}$ depends on $\theta_{w}=$ $\left[\boldsymbol{\delta}_{w}^{\prime}, c_{w}, \alpha_{w}, \beta_{w}\right]^{\prime}$ only not on any $\boldsymbol{\theta}_{\boldsymbol{i}}=\left[\boldsymbol{\delta}_{i}^{\prime}, c_{i}, \alpha_{i}, \beta_{i}, \kappa_{i}, \zeta_{i}, \boldsymbol{\lambda}_{i}^{\prime}, \boldsymbol{\xi}_{i}^{\prime}\right]^{\prime}$ for all $i$ and (2) The density of $r_{i, t}$ conditional on $I_{t-1}$ and $r_{w, t}$ depends on $\left[\boldsymbol{\theta}_{w}^{\prime}, \boldsymbol{\theta}_{i}^{\prime}\right]^{\prime}$ and not on any $\theta_{j}, j \neq i$ and the individual country specific shocks are independent across emerging markets [assumption (b) in (11)].

\subsection{Results}

We structure our discussion of the results in three parts. First, we will examine the parameter estimates of the world factor model and the diagnostics. Second, we will detail the implied level of integration, the time-varying correlation with the world and the importance of world factors. Finally, we examine some individual countries in greater detail. 


\subsubsection{Parameter estimates and diagnostics}

Table 3 presents some parameter estimates and residual diagnostics for the world factor model. In some countries, the estimation was ill-behaved. Global optima may not have been found in Nigeria, Portugal, Taiwan, Turkey, Venezuela and Zimbabwe. No estimation was attempted for Indonesia since there are too few observations.

Consider the factor ARCH restrictions. These models imply that $\kappa_{i}=\zeta_{i}$ and that the world factor impacts volatility at a constant rate. The first restriction, $\kappa_{i}=\xi_{i}$, is rejected in 14 of 19 countries at the $10 \%$ level of significance. The second restriction, $\psi_{i t}=\theta_{i t}$, is rejected in 17 of 19 countries. A joint test provides evidence against the factor ARCH restrictions in all 19 countries. The implication is that world factors affect volatility in a different manner through time. This is exactly what our model is designed to capture.

The results of estimating the extended covariance model are presented are also presentéd in Table 3. The restriction $f_{i}=\xi_{i}$ is examined with a likelihood ratio test. The restriction is not rejected in Argentina, Brazil, Chile, Malaysia, Mexico, and Turkey at the $10 \%$ level of significance. In two countries, Philippines and Portugal, the estimation of the extended model failed. When all of the covariance restrictions are simultaneously tested $\left(f_{i}=\xi_{i}\right.$ as well as $\left.g_{i}=k_{i}=0\right)$ there is much more evidence against our model's specification. Of the 11 countries where it was possible to estimate this version of the extended model, the restrictions were rejected for 7 (6) countries at the $10 \%(5 \%)$ level of significance.

Finally, the residual diagnostics are presented in the final columns of Table 3. These diagnostics test for serial correlation in the standardized disturbances of the model for the mean and variance. These tests reveal little evidence against the specification. The means test does not reveal a single rejection for the 19 countries. The test on the variance disturbances shows evidence against the specification in only Portugal.

It is possible that these residual diagnostic tests lack power. Importantly, these results must be taken together with the tests of the extended covariance 
specification which show evidence against the specification in many of the countries. Of course, our model is highly parameterized relative to the available data. It is perhaps not surprising that the specification is rejected in many countries. Nevertheless, it may be possible to learn something from a model which is statistically rejected.

\subsubsection{Correlation, integration and the importance of world factors}

Table 4 details the proportion of variance due to world factors, the average levels of market integration and the average conditional correlations from the world factor model.

The mean proportion of variance due to world factors is provided over the entire sample and for two subperiods. The first subperiod is the post October 1987 (post crash) period. The second subperiod is calculated after significant liberalizatíons. This subperiod is country specific. 17 of the 19 countries experienced capital market liberalizations (exceptions were Nigeria and Zimbabwe). This allows us to examine the hypothesis that the importance of world factors increases after capital market liberalizations.

The results suggest that only a small amount of variance is being driven by world factors. In 16 of the 19 countries, the average proportion of variance being driven by world factors is less than $10 \%$. The countries that are most affected by world factors are Malaysia, Portugal, Philippines, Greece, Mexico and Thailand.

In the subperiod beginning in November 1987, the degree of importance of world factors increases for 12 of 17 countries (Indonesia not estimated and Turkey's data begins after November 1987). This period often coincides with capital market liberalizations. In the post-liberalization period, the importance of world factors increases in 10 of 16 countries (no liberalizations in Nigeria and Zimbabwe). Some increases are particularly dramatic. For example, the importance of world factors triples in Thailand after their liberalization. In Greece, the influence of world factors doubles after their capital market liberalization. 
The changing importance of world factors is mirrored in the time-variation in conditional correlations with the world market portfolio. In 12 of 17 countries, correlations increase after capital market liberalizations. Again, there are a number of dramatic examples. In the full sample, the average conditional correlation of Thailand and the world market is $15.5 \%$. In the post-liberalization period the correlation increases to $37.9 \%$. Similarly, in the full sample, the correlation between the Mexican equity return and the world market return is $19.8 \%$. In the subsample since capital market liberalization, the correlation is $41.5 \%$.

Table 4 also presents the average level of mean and variance integration. The discussion on these parameters will be focussed on the three countries we examine in detail. Note that the interpretation of these numbers as "degree of integration" may be strong. They reflect the relative time-varying importance of global versus local factors in the mean and variance.

\subsubsection{Further analysis for specific countries}

While space does not permit a detailed examination of every country, we highlight in this section three important emerging equity markets: Korea, Mexico and Thailand.

\subsubsection{Korea}

Korea is the second largest of the "emerging" equity markets with market capitalization of $\$ 107.4$ billion at the end of 1992 . Liquidity is very good with average daily trading volume of $\$ 480$ million. Indeed, the capitalization of the equity market represents almost $50 \%$ of GDP. While this information suggests a well functioning integrated capital market, there have been a number of regulatory hurdles to foreign participation in Korean equity markets. Given these restrictions, one might assume that the Korean equity markets are not integrated with world capital mạkets. 
The foreign ownership rules were relaxed in January 1992 (just as our sample ends). Even with these "relaxed" regulations, foreign ownership is limited to only $10 \%$ of the market capitalization in so-called "unlimited industries," and $8 \%$ in the "limited industries" which include utilities, defense, shipping, transportation, finance and communications. The $10 \%$ limit was almost immediately raised to $25 \%$ for the companies that already had more than $10 \%$ foreign ownership. In addition, no single investor can own more than $3 \%$ of any Korean firm. Foreign investors must apply for an ID number from a Korean broker on the Korean Stock Exchange and all shares must be held in the owner's name. This liberalization still presents significant barriers to entry. ${ }^{9}$

Nevertheless, there are alternative ways to access Korean capital markets. At the end of 1992, there were 34 Korea funds trading either privately or listed on the New York Stock Exchange, London Stock Exchange, Hong Kong Stock Exchange. The ability to access Korean investments in this way could account for the estimated integration parameters presented in Figure 1a. The estimates support the idea that the Korean equity market is integrated into world capital markets and are consistent with the analysis presented in Bekaert and Harvey (1995).

Although the Korean market appears integrated, very little variation in the volatility is accounted for by world factors. Figure $1 \mathrm{~b}$ indicates that less than $10 \%$ of the variation is due to world factors in the base model and there has been little change through time. The small role of world factors is mimicked in the conditional correlations presented in Figure 1c. The influence of world factors is a function of the correlation, the degree of integration and the volatility ratio. Given that the first three elements are fairly constant through time, it is of little surprise that the ratio of world volatility to local volatility is fairly constant through time. This is evident in Figure 1d.

\footnotetext{
9 Bekaert (1995) provides a catalogue of barriers to entry. Also see Bae (1993).
} 


\subsubsection{Mexico}

Mexico is one of the largest emerging markets with a capitalization of US\$139 billion, high trading volume of US\$171 million daily and high GDP per capita of US\$2500. Most probably consider Mexico a reasonably "integrated" capital market. This opinion is perhaps influenced by its proximity to the U.S. or the large number of ADRs (36 in June 1992) and closed end funds (6 funds with capitalization of US\$16 billion). However, this prior belief is influenced by the recent capital flows to Mexico.

Figure 2a presents the time-series of the measures of integration for the mean, $\theta_{i, t-1}$, and for the variance, $\psi_{i, t-1}$. Both integration measures trend upwards until 1982 and then begin to decline. This coincides with the debt crisis which began in 1982.

The implied degree of integration sharply increases after 1988. This is especially evident for the measure of integration associated with the conditional variancè. ${ }^{10}$ This roughly coincides with significant capital market liberalizations. For example, after 1989, 100\% foreign investment in most firms is possible. Key sector firms are restricted to $49 \%$ foreign participation and the foreign investment limit in the banking industry is $30 \%$.

The effect of the capital market liberalization is particularly evident in the world factor proportions and the conditional correlations presented in Figures $2 \mathrm{~b}$ and 2c. These measures sharply increase after 1988.

The influence of world factors is accounted for by the degree of integration, the conditional correlation and the volatility ratio. Figure $2 \mathrm{~d}$ suggests that the volatility ratio does not contribute to the increased importance of world factors. While variable through time, it exhibits no particular trend.

10 There are a number of similarities and differences between the fitted integration series and the one presented in Bekaert and Harvey (1995). The series in Figure 2a and the one in Bekaert and Harvey (1995) both drop sharply in 1982. However, there is no clear pattern in the integration measure (which is restricted to the mean) after 1982. In contrast, the measure based on the variance in Figure 2a sharply increases after 1988. 


\subsubsection{Thailand}

Figure $3 a$ presents the time-series of market integration measures from the standard model for Thailand. The measures of integration for the mean, $\theta_{i, t-1}$, and for the variance, $\psi_{i, t-1}$, are presented. The average levels of these measures increase during 1987. This follows a number of liberalizations in the Thai market which culminate in December 1988. In particular, Bailey and Jagatini (1994) detail the opening of the Alien Board for extranational trading of Thai securities at this time. The measure for the mean is far more variable than the measure for the variance. ${ }^{11}$ The extended model results for Thailand are similar to the constrained, standard model. While not shown, the time-series patterns in both integration measures appear similar to the standard model.

The influence of world factors is detailed in Figure 3b. Before 1987, little to none of the variance in the Thai returns can be accounted for by world factors. This is also evident in the overall mean of 0.04 reported in Table 3. However, there is' a sharp increase after 1987. In recent years, world factors account for closer to $20 \%$ of the variation in the local variance.

Figure $3 c$ details the time-varying conditional correlations with the world market return. There is a sharp increase in the conditional correlations in 1987. However, this increase is not entirely due to the stock market crash in October. The correlations begin to increase in January 1987. In addition, the increase in conditional correlation in 1987 and 1988 does not appear to be transitory. The correlations level off to about $40 \%$ in the last three years of the sample. This is comparable to the average level of correlation that Harvey (1991) details for 17 developed market returns.

The influence of world factors can be decomposed into three pieces. We have detailed the first two: the degree of integration and the conditional correlation with the world. The final piece is the ratio of volatility: world to local. Figure

11 In Bekaert and Harvey (1995), a similar pattern in the integration parameter was detected based on the mean. Nevertheless, the evidence in Figure 3a is much more consistent with capital market liberalizations having some bite after December 1988. 
3d shows the time-series patterns in this ratio. Since 1984, the ratio has been decreasing (Thai volatility higher relative to world volatility).

\section{The cross-section of volatility in emerging markets}

\subsection{Explaining volatility across emerging markets}

One important difference between developed and emerging capital markets, is the dispersion of volatility across countries. Harvey (1993) shows that the range of unconditional volatilities in developed markets is $18 \%$ (from high to low). In emerging markets, the range is $86 \%$ (18\% for Jordan and $104 \%$ for Argentina). We explore four sources of volatility differences: asset concentration, stock market development/economic integration, microstructure effects, and finally macroeconomic influences and political risk.

The most obvious source is the degree of diversification and concentration inherent in the IFC index for each country. Schwert (1989a), Harvey (1991) and Roll (1992) explore whether the number of stocks included in the index influences the cross-section of volatility. We construct a time-series of the number of stocks included in each of the IFC country indices. Following previous research, we use the natural logarithm of the number of stocks as a proxy for the degree of diversification.

The number of stocks in the index may not be that revealing of diversification if there are few dominant stocks and many small stocks. Roll (1992) and Harvey (1995c) examine asset concentration ratios:

$$
C R_{i, t}=\sqrt{\frac{N_{i, t}}{N_{i, t}-1} \sum_{j=1}^{N_{i, t}}\left(w_{i j, t}-\frac{1}{N_{i, t}}\right)^{2}}
$$

where $N_{i, t}$ are the number of individual securities in the country $i$ index in month $t$ and $w_{i j, t}$ is the share of market capitalization represented by stock $j$ at time $t$. If one stock dominates the index, then $C R$ gets close to one. If every stock has equal market capitalization, then $C R=0$. Using the EMDB's individual stock data, we create time-series of concentration ratios for each country. 
A country index may have many stocks and a low concentration ratio but may still not be diversified if all of the stocks are involved in a single industry. Divecha, Drach and Stefan (1992) construct industry concentration ratios for a single year using all available securities in 20 emerging markets. Harvey (1995c) finds that these industry concentration data have only limited ability to explain unconditional variance differences over the past five years. Given that a timeseries of industry classifications is not available, we are unable to examine the effect of industrial concentration on the cross-section of volatility.

The second source is linked to both the development of stock market and the degree of market integration. Unfortunately, exact measures of stock market development and economic integration are difficult to specify. We consider several proxies. First, we compute the cross-sectional volatility of the country's component stock returns at each point in time. As an economy becomes more developed, it often becomes more diverse. If this diversity is reflected in the firms whose equity is part of the IFC indices, then we would expect the cross-sectional volatility of the country's component stocks returns to increase. That is, as stocks are less dependent on one sector, their covariances should decrease which should increase the cross-sectional variance. At the level of the index, this effect should decrease market volatility. Hence, our first measures of stock market development are the cross-sectional standard deviation of each index's component stock returns and the cross-sectional mean absolute deviation. These are measured each month relative to the average stock return in each country index. This interpretation of the cross-sectional standard deviation will not necessarily hold in more developed markets.

We also consider a number of additional proxies for stock market development and economic integration. Bekaert and Harvey (1995) propose a model where market integration is parameterized. They find that equity capitalization to GDP is a useful instrument in characterizing the time-series of market integration. Stock market capitalization to GDP is also often used as a stock market development indicator [see Demirguc-Kunt and Levine (1993)]. We also track the size of the trade seetor by forming the ratio of exports plus imports to GDP. 
The third source of volatility arises from market microstructure research. It is well known that the heterogeneity of traders' information sets as well as liquidity affects the variance of returns. We proxy for these effects by examining the roles of the number of stocks traded in any month and turnover ratios in explaining the cross-section of volatility. In more developed markets, large changes in prices across securities suggest that more private information is being revealed to the market. In the model of Ross (1989), the volatility of prices is directly linked to the rate of information flow in the market. Hence, increases in the cross-sectional volatility could raise the variance of the distribution of future prices.

The fourth category focusses on macroeconomic volatility which Schwert (1989a,b) shows is one of the underlying forces affecting stock market volatility. Unfortunately, the macroeconomic data are sparse or nonexistent in some of the emerging markets. For instance, inflation variability is an obvious candidate for an explanatory variable. However, the data are quite difficult to obtain and, even if we used the published data, they are highly suspect in a number of countries. Since purchasing power parity is not rejected in high inflation countries [see Liew (1995)], we use the variability of foreign exchange rate changes to proxy for inflation variability.

Finally, political risk is also a likely candidate to influence the cross-section of volatility. A time-series of political risk ratings is difficult to obtain. ${ }^{12}$ We chose to focus on Institutional Investor's Country Credit Ratings. These ratings are based on a semi-annual survey of bankers. Institutional Investor has published this survey in its March and September issues every year since 1979. The survey represents the responses of 75-100 bankers. Respondents rank each country on a scale of 0 to 100 , with 100 representing the smallest risk of default. Institutional Investor weights these responses by its perception of each bank's level of global prominence and credit analysis sophistication [see Erb, Harvey and Viskanta $(1994,1995)$ ].

Credit ratings are not meant to solely represent a measure of political risk.

12 One of the best known rating services, Business International's Country Assessment Service, began ratings in 1971. It was sold in 1986 to The Economist. While the recent data from the Economist's Intelligence Unit are available, the historical data has not been recompiled. 
Many macroeconomic, as well as political factors, enter the bankers' decisions on the credit worthiness of a particular country. This variable captures both political risk and macroeconomic stability. It is the only variable that we examine that is ex ante (in the sense that participants are asked to assess the future credit worthiness).

\subsection{Methodology}

The raw material for the cross-sectional analysis are the time-series estimates of conditional volatility. We estimate a pooled time-series cross-sectional regression:

$$
\ell n\left(\sigma_{i}^{2}\right)=\alpha_{i}+\beta^{\prime} \mathbf{X}_{i}+\boldsymbol{u}_{i} \quad i=1, \ldots, N
$$

There are $N$ countries. $\sigma_{i}^{2}$ is a $T_{i} \times 1$ vector of preestimated conditional variances where $T_{i}$ is the number of observations for country $i, \mathbf{X}_{i}$ is a matrix of $L$ explanatory variables for country $i, \alpha_{i}$ are a set of intercept coefficients (one for each country), and $\beta$ is a $L \times 1$ coefficient vector. We use the conditional variance estimates from the univariate, segmented volatility model. To check robustness, we also report results using the world factor specification.

This model allows for fixed effects in the cross-section by not imposing that the intercepts are identical across different countries. However, we also examine a specification in which the intercepts are constrained to be constant across countries. This allows us to test how much of the variation in volatility is explained by the specified variables. Our approach allows us to examine all observations for all countries simultaneously.

Our initial estimation technique is ordinary least squares using the standard White (1980) correction for conditional heteroskedasticity. A standard Lagrange multiplier test reveals substantial evidence against homoskedasticity across countries. ${ }^{13}$ Hence, we also present a generalized least squares estimation which

\footnotetext{
13 We adjusted the standard test discussed in Greene (1993) for the unequal number of observations present in our analysis.
} 
allows for heteroskedasticity across countries ("group-wise heteroskedasticity"). Finally, we present estimates which correct for both group-wise heteroskedasticity and serial correlation. The serial correlation correction, which is detailed in Greene (1993), is specific to each country and is based on the Prais-Winsten method. This correction is particularly important given the extreme serial correlation in some of the countries' fitted volatility estimates.

Our formulation forces the coefficients to be identical through time. One way to avoid this assumption is to estimate the model month by month. However, between 1976 and 1981 we only have nine countries in the cross-section. As a result, we do not have the degrees of freedom to feasibly estimate at each month.

\subsection{Results}

\subsubsection{Summary analysis}

The fitted volatility series cover (at most) 1977:01 to 1992:12. There are a total of 2627 fitted variances. However, the country credit ratings only begin in 1979:03. As a result, for nine countries 32 observations are lost, reducing the total number of observations to 2339 .

Some summary statistics on the variables used in the cross-sectional regressions are included in Table 5. The average values of the cross-sectional standard deviation, number of firms in each index, asset concentration factor, country credit rating, trade to GDP and market capitalization to GDP are presented in this table. Correlation of the average volatilities and these variables are presented in Table 6 .

While the correlations are only based on 20 observations, there is much to be learned. There appears to be a positive relation between the cross-sectional standard deviation and the volatility. The largest cross-sectional standard deviation is found in Argentina (which also has the largest volatility).

There appears to be a weak negative relation between country credit ratings and volatility. Lower quality ratings are generally associated with higher volatility. 
However, one observation, Taiwan, is very influential. Taiwan has the highest credit rating and also the fourth highest volatility.

The correlation matrix suggests that there is a weak positive relation between the average number of companies in the index and volatility. This implies that a larger number of companies in the index increases volatility. However, the relation is not significant.

The analysis of concentration factors is difficult to interpret. The correlation analysis reveals a negative relation between concentration and volatility. However, the analysis is highly influenced by Jordan, which has the highest concentration factor and the lowest volatility. Without Jordan, there appears to be a positive relation (more big firms implies higher volatility).

There is a distinct negative relation between exports plus imports divided by GDP and volatility. This suggests that the more open the economy is to trading, the lower the volatility. The correlation between these variables is $-38 \%$.

There is also a negative relation between market capitalization to GDP and volatility. This relation is weakened by two influential observations: Malaysia and Taiwan. Both of these countries have very high capitalizations to national output ratios and high volatility.

\subsubsection{Time-series cross-sectional analysis}

The time-series cross-sectional regression results are presented in Table 7. Panel A considers the estimation with the standard White (1980) correction for heteroskedasticity. The results which correct for group-wise heteroskedasticity are presented in Panel B and the estimation which corrects for both group-wise heteroskedasticity and serial correlation is in Panel C. In the base case with no country-specific intercepts, $34 \%$ of the cross-section of volatility is explained with the eight variables. Separate regressions are run with the cross-sectional standard deviation of the individual index stocks and the cross-sectional mean absolute deviation because these measures are $99 \%$ correlated. When the country specific 
intercepts are included, the explanatory power of the regressions increases to $60 \%$.

The way the cross-sectional standard deviation enters the regression depends on the level of market development. As such, we allow this variable to enter the regression as an interaction variable associated with the deviation from the cross-sectional mean market capitalization to GDP ratio. If $M C_{t}^{i} / G D P_{t}<$ $\overline{\left(M C_{t} / G D P_{t}\right)}$ which is, for example, always true for Zimbabwe, Brazil, Pakistan, then an increased cross-sectional standard deviation negatively affects the market volatility. If $M C_{t}^{i} / G D P_{t}>\overline{\left(M C_{t} / G D P_{t}\right)}$, then the derivative of volatility with respect to the cross-sectional standard deviation is positive which is what is predicted by the information flow model of Ross (1989). The results provide some support for this specification. Both the cross-sectional standard deviation and the interaction term enter the regression with coefficients more than 1.6 standard errors from zero in Panels A and B. The coefficients are positive for the regression with standard deviations in panel $\mathrm{C}$ but not significantly different from zero.

The number of companies in the index has a negative coefficient that is about two standard errors from zero in the base estimation. This implies that a larger number of companies decreases volatility. This is exactly what one would expect. However, in Panels B and C, this variable fails to play a significant role.

The evidence on the concentration factor is somewhat puzzling. This factor is weakly negatively related to volatility. That is, a country with a few highly concentrated firms is likely to have lower volatility. This variable is highly significant in all the regressions with fixed effects in panels $\mathrm{A}$ and $\mathrm{B}$. In panel $\mathrm{C}$, the coefficient is less than two standard errors from zero in the fixed effects regression. We investigated the influence of Jordan by adding a slope dummy variable for this country. There was still a negative effect. The results suggest that markets with a few very large stocks have lower volatility.

The relation between turnover and volatility is difficult to interpret. There are two countries, Taiwan and Korea, with turnover ratios an order of magnitude greater than the other countries. Using 18 countries, there is weak negative relation between turnover and volatility when measured by averages. However, in the time-series cross-sectional regression, turnover is positively related to volatil- 
ity. Since the turnover data begin in 1986, a separate regression is estimated with turnover included and the coefficients are reported in the far right column of panel A of Table 7 .

In many of the regressions, the country credit rating enters with a negative coefficient. This implies that a lower credit rating is associated with higher volatility. This variable is often significant in panels $A$ and $B$ and less significant in panel C.

There is also a very significant negative relation between the size of the trade sector and volatility. In the regression without country specific dummy variables, the trade sector is often more than 5 standard errors from zero irrespective of the standard error correction. A more open economy is associated with lower volatility.

The market capitalization to GDP ratio enters the regression with a positive sign in panels $A$ and $B$. This is unexpected given the correlation analysis suggested a negative relation (larger equity market implies lower volatility). However, this variable is highly correlated with the trade variable $(70 \%)$. When the regression is run without the trade variable, the market capitalization ratio enters with a less significant coefficient. In addition, in the estimation which corrects for serial correlation and heteroskedasticity, this variable enters with a positive coefficient which is more than two standard errors from zero.

Finally, the volatility of foreign exchange rate changes plays a very important role in explaining equity return volatility. In the regression without fixed effects the coefficient on this variable is 15 standard errors from zero. When country dummy variables are allowed, the coefficient is six standard errors from zero. The significance of this variable may be not that surprising given that we are measuring equity returns in U.S. dollars although it may also capture inflation variability.

In addition, an extensive sensitivity analysis is conducted. In the univariate models where the $\alpha_{i}+\beta_{i}$ constraint was binding, we reestimated removing the constraint. When these fitted values were used in the time-series cross-sectional analysis, there was little difference in the results.

In another exercise, we used the fitted variances from the world factor estima- 
tion (except for Indonesia) in the time-series cross-sectional analysis. The results are broadly consistent with those reported in Table 7 . In panel D, we report two of the estimations using the world factor variances. This estimation corrects for the group-wise heteroskedasticity and serial correlation. Although most results are robust, there are a few differences. The cross-sectional standard deviation variable now enters with a positive sign and the interaction term with MCGDP also obtains a positive and much larger coefficient. Although the coefficients are not statistically significant, the effects are as expected: for countries with large market capitalizations, increases in the cross-sectional standard deviation reduce volatility.

Overall, the sensitivity analysis and the results in Table 7 suggest that the prespecified variables capture an important part of both the cross-section and time-series of volatility.

\subsection{Capital market liberalization and volatility}

Figure 4 informally characterizes the effect of capital market reforms on variance. The average conditional variance two years after the reform is depicted on the $y$-axis and the average conditional variance two years before the reform is presented on the $x$-axis. On average, if there is no effect on volatility the variances should fall around the $45^{\circ}$ line. If variance decreases, then many of the points should fall below this line.

The major liberalization dates are from Bekaert (1995) and are contained in Table 8. The evidence in Figure 4 suggests that volatility decreases after liberalizations. Of the 17 countries, where there was a liberalization within our sample, only 4 show evidence of increased volatility (Pakistan, Colombia, Venezuela and Turkey). In most countries, volatility decreases. Particularly dramatic decreases are found for Taiwan, Mexico, Portugal, Argentina and Brazil. The evidence for Brazil is consistent with the empirical findings in Bekaert, Garcia and Harvey (1995b)... 
A weakness of this analysis is that other events could occur that decrease or increase volatility that have little to do with capital market liberalizations. Therefore, we introduce liberalization dummy variables into our cross-sectional analysis and test whether, after controlling for these factors, these interventions significantly decrease volatility.

The results are contained in panels $A$ through $D$ of Table 7 . We introduce four dummy variables to break each of the 17 countries' volatility into four pieces: early (more than 30 months before liberalization), pre (30 to six months prior to liberalization), during (six months prior to three months after liberalization) and post (four months after liberalization to end of sample.) The logic here is that when liberalizations are pre-announced or anticipated by market participants, volatility may change some time before the liberalization date.

Consider Panel A of Table 7. The pre, during and post indicators enter with coefficients that are significantly different from zero. In both the regressions that use standard deviations and mean absolute deviations, the coefficient on the post-liberalization indicator is lower than the coefficient on the pre-liberalization indicator. For example, in the regression that uses mean absolute deviation, the post-liberalization coefficient is 0.279 and the pre-liberalization coefficient is 0.345 . We also conducted a heteroskedasticity consistent Wald test of the the hypothesis that the coefficient on the pre and post-liberalization dummy variables were the same. The null hypothesis is not rejected with a p-value of 0.229 .

The evidence of a volatility change after liberalization in much sharper in the estimations which use generalized least squares. For example in the regression which corrects for group-wise heteroskedasticity and uses standard deviation, the coefficient on the pre-liberalization indicator is 0.130 and the coefficient on the post-liberalization in -0.037 . The heteroskedasticity consistent Wald test provides a rejection of the null hypothesis at the 0.001 level of significance. Similarly, in the regressions which correct for both group-wise heteroskedasticity and serial correlation, the Wald test provides evidence against the null hypothesis at the 0.007 level of significance.

To check robustness, panel $D$ reports the results using the conditional vari- 
ances of the world factor model with the correction for group-wise heteroskedasticity and serial correlation. In both specifications, the post liberalization volatility is slightly but not statistically significantly lower than the pre liberalization volatility.

\subsection{Economic significance of the results}

In the preceding discussion, we have analyzed the statistical significance of various influences on volatility in emerging markets. In this section, we explore which factors are economically significant. To do so, we conduct the following experiment. Consider a relatively closed country with a not very well developed stock market. Such a country is likely to be characterized by high stock market volatility, a low cross-sectional standard deviation, a high concentration ratio, and low market capitalization to GDP. There may be political risk reflected in a low credit rating and unstable macroeconomic policies translating into high foreign exchange volatility. To make this more concrete, we interpret high (low) as the $75 \%(25 \%)$ quartile in the cross-sectional distribution of the relevant variables using all the observations for all the countries over the full sample.

Panel A of Table 9 reports the relevant data characteristics for this hypothetical country (the 25 th percentile). Suppose this country opens up its capital markets and becomes a "median" country, in terms of concentration ratios, openness, political risk and the other factors. We use the cross sectional regressions to predict what would happen to its (annualized) equity volatility. This exercise also allows us to assess the impact of the different estimation techniques on the model predictions.

Panel B of Table 9 details the partial effects of each of the variables. The crosssectional standard deviation or mean absolute deviation, the concentration ratios and the market capitalization to GDP have relatively minor and/or inconsistent effects. The number of companies in each index has a negative contribution (more firms less volatility) in the OLS model and the world factor model. The credit 
rating variable has a negative contribution (higher rating lower volatility) in the world factor model. The trade sector to GDP, foreign exchange volatility and liberalization indicators have consistent important contributions. When the effects are cumulated, the implication for volatility is remarkably consistent across the estimation methods. With the univariate variance estimation, the cumulative effect on volatility ranges from $-6.0 \%$ to $-7.2 \%$. Using the world factor variances, the cumulative effect on volatility ranges from $-6.0 \%$ to $-6.6 \%$. In other words, the move from the $25 \%$ percentile to the median for the hypothetical emerging market, reduces volatility by at least $6.0 \%$.

\section{Conclusions}

Our research has a number of goals. First, we are interested in characterizing volatility in emerging markets. Volatility is an important input for asset allocation decisions. In segmented capital markets, country volatility is a critical input in the cost of capital calculation. However, volatility is difficult to model in these markets. We present a number of volatility models, allow for very general error distributions, and provide a battery of diagnostic tests.

Second, we are interested in the forces that affect the time-series of volatility in these emerging equity markets. In fully integrated markets, we believe that volatility is strongly influenced by world factors. In segmented capital markets, volatility is more likely influenced by local factors. Our decomposition of the sources of variation in volatility helps shed light on the degree of integration of each market with world capital markets and on how the degree of integration varies over time.

Third, we explore the forces that determine why volatility is different in the various emerging markets. We construct a number of variables: number of firms in the country index, asset concentration factors, country credit ratings, crosssectional standard deviation of the individual stock returns within the indexes, size of the trade sectors to GDP, and market capitalization to GDP ratios. Among other intêresting findings, we show that more open economies (in terms of world 
trade) have significantly lower volatilities. We also find that political risk as proxied by credit quality explains a large amount of the cross-sectional variation in volatility.

Finally, we study the effect of capital market liberalizations on volatility. Given our time-series models, we investigate whether volatility decreases after liberalizations. Our evidence suggests that volatility either remains the same or decreases in 13 of 17 countries. There is a sharp drop in volatility in five countries in our sample. Even after controlling for all the potential influences on the timeseries and cross-section of volatility, we find that capital market liberalizations significantly decrease volatility in emerging markets. 


\section{References}

Andrews, Donald W. K., 1991, Heteroskedasticity and autocorrelation consistent covariance matrix estimation, Econometrica 59, 817-858.

Bae, Kee-Hong, 1993, Time-variation in the price of risk and the international capital market structure, Unpublished dissertation, The Ohio State University.

Bailey, Warren and Julapa Jagtiani, 1994, Foreign ownership restrictions and premiums for international investment: Some evidence from the Thai capital market, Journal of Financial Economics 36, 57-88.

Bekaert, Geert, 1995, Market integration and investment barriers in emerging equity markets, World Bank Economic Review 9, 75-107.

Bekaert, Geert, Marcio Garcia and Campbell R. Harvey, 1995a, The contribution of speculators to effective financial markets, Catalyst Monograph Series, Catalyst Institute, Chicago, IL.

Bekaert, Geert, Marcio Garcia and Campbell R. Harvey, 1995b, The role of capital markets in economic growth, Catalyst Monograph Series, Catalyst Institute, Chicago, IL.

Bekaert, Geert and Campbell R. Harvey, 1995, Time-varying world market integration, Journal of Finance 50, 403-444.

Bekaert, Geert and Robert Hodrick, 1992, Characterizing predictable components in excess returns on equity and foreign exchange markets, Journal of Finance 47, 467-509.

Black, F., 1976, Studies of stock market volatility changes, Proceedings of the 1976 Meetings of the American Statistical Association, Business and Economics Statistics Section, 177-81.

Bollerslev, Tim, 1986, Generalized autoregressive conditional heteroskedasticity, Journal of Econometrics 72, 307-327.

Bollerslev, Tim, and Jeffrey M. Wooldridge, 1992, Quasi-maximum likelihood estimation and inference in dynamic models with time-varying covariances, Econometric Reviews 11, 143-172.

Bonser-Neal, Catherine, Gregory Brauer, Robert Neal and Simon Wheatley, 1990, International investment restrictions and closed-end country fund prices, Journal of Finance $45,523-548$.

Campbell, John Y. and Yasushi Hamao, 1992, Predictable stock returns in the United States and Japan: A study of long-term capital market integration, Journal of Finance 47, 43-70.

Chen, Nai-fu, Richard Roll and Stephen A. Ross, 1986, Economic forces and the stock market, Journal of Business 59, 383-03.

Christie, Andrew A., 1982, The stochastic behavior of common stock variances: Value, leverage and interest rate effects, Journal of Financial Economics 10, 407-432.

Claessens, Stijn, Susmita Dasgupta and Jack Glen, 1995, Return behavior in emerging markets, World Bank Economic Review, 131-151.

Cumby, Robert E. and Anya Khanthavit, 1992, A Markov switching model of market integration, Unpublished working paper, New York University.

Diebold, F. and M. Nerlove, 1989, The dynamics of exchange rate volatility: A multivariate 
latent factor ARCH model, Journal of Applied Econometrics 4, 1-21.

DeSantis, Giorgio and Selahattin Imrohoroglu, Stock returns and volatility in emerging financial markets, Unpublished working paper, University of Southern California, Los Angeles, CA.

Engle, Robert F., 1982, Autoregressive conditional heteroskedasticity with estimates of U.K. inflation, Econometrica 50, 987-1008.

Engle, Robert F. and G. Gonzalez-Rivera, 1991, Semiparametric ARCH models, Journal of Business and Economic Statistics 9, 345-359.

Engle, Robert F., David M. Lilien and Russell P. Robbins, 1987, Estimating time varying risk premia in the term structure: The ARCH-M model, Econometrica 55, 391-407.

Engle, Robert F. and Victor M. Ng, 1993, Measuring and testing the impact of news on volatility, Journal of Finance 48, 1749-1778.

Engle, Robert F., Victor M. Ng and Michael Rothchild, 1990, Asset Pricing with factor-ARCH structure: Empirical estimations for Treasury bills, Journal of Econometrics 45, 213-237.

Engle, Robert F., Victor M. Ng and Michael Rothchild, 1992, A multi-dynamic factor model for stock returns, Journal of Econometrics 52, 245-266.

Erb, Claude, Campbell R. Harvey and Tadas Viskanta, 1994, Forecasting international equity correlations, Financial Analysts Journal November-December, 32-45.

Erb, Claude, Campbell R. Harvey and Tadas Viskanta, 1995, Country risk and global equity selection, Journal of Portfolio Management, 21, Winter, 74-83.

Ferson, Wayné E. and Campbell R. Harvey, 1993, The risk and predictability of international equity returns, Review of Financial Studies 6, 527-566.

Garcia, René and Eric Ghysels, 1994, Structural change and asset pricing in emerging markets, Unpublished working paper, Université de Montréal.

Gibbons, M. R. and W. E. Ferson, 1985, Tests of asset pricing models with changing expectations and an unobservable market portfolio, Journal of Financial Economics 14, 217-236.

Glosten, Lawrence R., Ravi Jagannathan, and David E. Runkle, 1993, On the relation between the expected value and the volatility of the nominal excess return on stocks, Journal of Finance 48, 1779-1802.

Gray, Stephen F., 1993, Capturing the nonlinearities in short-term interest rates: A new class of regime-switching models, Unpublished working paper, Stanford University.

Gray, Stephen F., 1994, Semi-parametric ARCH: Evidence from the foreign currency market, Unpublished working paper, Stanford University.

Hansen, Lars P., 1982, Large sample properties of generalized method of moments estimators, Econometrica 50, 1029-1054.

Hansen, Lars P. and Robert J. Hodrick, 1983, Risk averse speculation in forward foreign exchange markets: An econometric analysis of linear models, in Jacob A. Frenkel, ed.,: Exchange rates and international macroeconomics (University of Chicago Press, Chicago, IL).

Harvey, Campbell R., 1991, The world price of covariance risk, Journal of Finance 46, 111-157.

Harvey, Campbell R., 1993, Portfolio enhancement using emerging markets and conditioning information, in Stijn Claessens and Shan Gooptu, Eds., Portfolio investment in develop- 
ing countries (Washington: The World Bank Discussion Series, 1993, pp. 110-144).

Harvey, Campbell R., 1995a, Predictable risk and returns in emerging markets, Review of Financial Studies 8, 773-816.

Harvey, Campbell R., 1995b, The risk exposure of emerging markets, World Bank Economic Review, 9, 19-50.

Harvey, Campbell R., 1995c, The cross-section of volatility and autocorrelation in emerging equity markets, Finanzmarkt und Portfolio Management 9, 12-34.

Heston, Steven, and K. Geert Rouwenhorst, 1994, Does industrial structure explain the benefits of international diversification, Journal of Financial Economics 36, 3-27.

International Finance Corporation, 1993, IFC index methodology, Washington: World Bank.

Kim, E. Han and Vijay Singal, 1994, Opening up of stock markets: Lessons from emerging economies, Unpublished working paper, Virginia Tech.

King, Mervyn, and Sushil Wadhwani, 1990, Transmission of volatility between stock markets, Review of Financial Studies 3, 5-33.

King, Mervyn, Enrique Sentana and Sushil Wadhwani, 1994, Volatility and the links between national stock markets, Econometrica 62, 901-934.

Liew, John M., 1995, Stock returns, inflation and the volatility of growth in the money supply: Evidence from emerging markets, working paper, Graduate School of Business, University of Chicago.

Longin, F. and B. Solnik, 1994, Is the correlation in international equity returns constant: 1960-1990?, Financial Analysts Journal.

Nelson, D. B., 1991, Conditional heteroskedasticity in asset returns: A new approach, Econometrica 59, 347-370.

Richardson, Matthew and Tom Smith, 1993, A test for multivariate normality in stock returns, Journal of Business 66, 295-321.

Roll, Richard, 1992, Industrial structure and the comparative behavior of international stock market indexes, Journal of Finance 47, 3-42.

Ross, Stephen A., 1989, Information and volatility: The no-arbitrage martingale approach to timing and resolution irrelevancy, Journal of Finance 44, 1-17.

Schwert, G. William, 1989a, Why does stock market volatility change over time? Journal of Finance 44, 1115-1154.

Schwert, G. William, 1989b, Business cycles, financial crises and stock volatility, CarnegieRochester Conference Series on Public Policy 31, 83-126.

White, Halbert, 1982, Maximum likelihood estimation of misspecified models, Econometrica 50, 1-26.

World Bank, 1993, Emerging stock markets factbook, International Finance Corporation, Washington, D.C.

Zakoian, J. M., 1990, Threshold heteroskedastic models, D. P. INSEE. 


\section{Appendix: Estimation and testing of univariate, segmented models}

\section{A.1 Specification tests}

We present the standard battery of specification tests. However, we are most interested in distinguishing the model's overall performance. To this end, we propose the following test which is inspired by the presentation in Nelson (1991). Consider the standardized residuals, $\hat{z}_{t}=\hat{\epsilon}_{t} / \hat{\sigma}_{t}$. Under the null hypothesis that the model is correctly specified:

$$
\begin{aligned}
& \text { (a) } E\left[\hat{z}_{t}\right]=0 \\
& \text { (b) } E\left[\hat{z}_{t}^{2}-1\right]=0 \\
& \text { (c) } E\left[\hat{z}_{t} \hat{z}_{t-j}\right]=0 \quad j=1, \ldots, k \\
& \text { (d) } E\left[\hat{z}_{t}^{3}-s k\right]=0 \\
& \text { (e) } E\left[\hat{z}_{t}^{4}-k u\right]=0 \\
& \text { (f) } E\left[\left(\hat{z}_{t}^{2}-1\right)\left(\hat{z}_{t-j}^{2}-1\right)\right]=0 \quad j=1, \ldots, k
\end{aligned}
$$

where $s k$ represents the skewness parameter and $k u$ is the kurtosis. The correct specification of the conditional mean is implicit in (A1c). The conditional variance is in (A1f). In (Ala,b,d,e), the unconditional moments of $\hat{z}$ are compared to the ones predicted by the model.

In the standard setup, model I, $s k=0$ and $k u=3$. For model II, the skewness is also equal to zero, $s k=0$, but the kurtosis is $k u=3(\hat{\nu}-2) /(\hat{\nu}-4)$. For the SPARCH model, the skewness is:

$$
s k=\hat{p}\left(\hat{\mu}_{1}^{3}+3 \hat{\sigma}_{1}^{2} \hat{\mu}_{1}\right)+(1-\hat{p})\left(\hat{\mu}_{2}^{3}+3 \hat{\sigma}_{2}^{2} \hat{\mu}_{2}\right),
$$

and the kurtosis:

$$
k u=\hat{p}\left(6 \hat{\mu}_{1}^{2} \hat{\sigma}_{1}^{2}+3 \hat{\sigma}_{1}^{4}+\hat{\mu}_{1}^{4}\right)+(1-\hat{p})\left(6 \hat{\mu}_{2}^{2} \hat{\sigma}_{2}^{2}+3 \hat{\sigma}_{2}^{4}+\hat{\mu}_{2}^{4}\right) .
$$

Notice that the SPARCH model collapses to model I $(k u=3, s k=0)$, when $p=1, \mu_{1}=0$ and $\sigma_{1}=1$. 
Much like our normality tests, it is straightforward to use generalized method of moments to conduct specification tests. ${ }^{13}$ The conditional mean specification is tested by setting $k=6$ and obtaining a $\chi^{2}$ statistic from (A1c). A similar test is conducted on the conditional variance in (A1f). The distributional assumptions of the model are tested by examining (A1a,b,d,e). This results in a $\chi^{2}$ statistic with four degrees of freedom. It is also possible to jointly test all of the restrictions. With $k=6$, there are 16 degrees of freedom in the test statistic.

\section{A.2 Baseline estimation}

Table A1 presents the parameter estimates for the three models: normal, tdistribution and SPARCH and Table A2 presents detailed diagnostics of the three specifications. Given the results in Table 1, which shows very high unconditional variance and sharp departures from normality, it is no surprise that these are extremely difficult variance processes to fit.

In Table A4, we conduct diagnostics on both model residuals and scaled residuals. In the first panel, we analyze the residuals. The Cumby-Huizinga (1992) $\ell$-statistic is a test for serial correlation that is robust to heteroskedasticity and corrects for the fact that the residuals are estimated. However, the test is only strictly valid when the model is estimated using ordinary least squares or instrumental variables techniques. The $Q_{2}$-test is the standard Box-Pierce test for heteroskedasticity and tests for persistence in the squared residuals. Finally, we report skewness and kurtosis of the residuals. In the second panel, we scale the residuals by dividing them by the conditional standard deviation. The specification tests detailed in section 3.2 are detailed in these panels.

Consider the analysis of the three models' residuals reported in panel $\mathrm{A}$ of Table A3. First, the residuals of all three models for most of the countries are autocorrelated. The Cumby-Huizinga test shows significant serial correlation in

13 However, in contrast to the normality tests, the specification tests will be based on moments from generated time series. 
the residuals for 13 of 20 countries when the normal model is estimated; 10 of 19 for the SPARCH model (estimation failed to converge for Chile); and 14 of 20 countries for the model based on the t-distribution. This serial correlation occurs despite the fact that the lagged returns appear in the conditional mean specification. Indeed, the lagged return enters the specification more than one standard error from zero in 13 of the 20 countries for the normal model (parameter $\delta_{2}$ ). The residual serial correlation suggests that the specification of the conditional mean could be incorrect.

The analysis of squared residuals suggests that there is significant heteroskedasticity in the data. This test, however, only measures the multiple correlation of past squared residuals. Significant autoregressive conditional heteroskedasticity is found in about half of the countries examined. There is little variation across the different models.

Finally, the distributional characteristics of the residuals are examined. With only a few exceptions, the distributional features of the residuals are similar across the different models. The analysis indicates that the residuals depart from normality. For example, after estimating the model based on the normal distribution, significant skewness is detected in 8 of 20 countries and kurtosis departs from the value implied by a normal distribution in 9 countries. The significant kurtosis in the residuals suggests that a model based on the t-distribution may be more appropriate. The residual skewness motivates going to the SPARCH model which allows for fairly general skewness and kurtosis.

Now consider the parameter estimates and the diagnostics based on standardized residuals. The first model presented is based on the normal distribution. Given the evidence on the distribution of the returns and residuals, this model is the most likely to be rejected. The diagnostic results show that 7 of the 20 countries show significant covariance of current and past standardized residuals (mean test) and 9 countries have predictable squared standardized residuals (variance test). When we test the null hypothesis that residuals have a zero mean, unit standardized variance, zero skewness and kurtosis equal to three, the null is rejected at the $5 \%$ level for 14 of the 20 countries. When all of the standardized 
residual tests are combined, the joint test reveals a rejection of the specification for all 20 countries.

As mentioned above, the model based on the t-distribution attempts to accommodate some of the kurtosis found in the residuals. One extra parameter, the degrees of freedom in the student t-distribution, $\nu$, is estimated. For the fourth moment to be well defined, this parameter must be greater than four. However, the estimation presented in Table A1 reveals that in six countries (Argentina, Colombia, Greece, Nigeria, Pakistan, and Turkey), the degrees of freedom parameter is less than four.

The analysis of the standardized residuals in the second panel of Table A2 shows that the null hypothesis of no predictability of the standardized residuals is rejected in 4 of the 14 countries where the model presented a degrees of freedom parameter greater than four. The squared standardized residuals are predictable in 7 of 14 countries. The moment test presents rejections for 10 of 14 countries. The joint test suggests that the restrictions implied by the null hypothesis (standardized residuals follow a t distribution) are rejected for all countries.

The SPARCH model which allows for general nonnormalities fares slightly better than the two fully parametric models. Underlying the SPARCH is a mixture of normal distributions. As a result, three additional parameters are estimated: the mean and variance of the second normal distribution and the mixing parameter. In some of the countries (Colombia, Malaysia, Mexico, and Pakistan), the mixing parameter is greater than 0.96 . The model did not converge for Chile and Portugal. In addition, Nigeria's results are suspicious.

The null hypothesis of no predictability of the standardized residuals is rejected in only 6 of the 20 countries compared to 7 of 20 for the normal model. The squared standardized residuals are predictable in 12 of 20 countries (9 of 20 for the normal model). The test that the standardized residuals' moments match the theoretical moments implied by mixture of distributions is rejected in 14 of 20 countries (compared to 14 of 20 for the normal model and 10 of 14 for the tdistribution). Similar to the other models, the joint test reveals evidence against the null hypothesis for almost all the countries' specifications. 
Figure A1 presents the fitted variances for the three models for each of the countries. The thin solid line represents the GARCH model with the normal distribution. The thin dotted line is the model with the $t$-distribution The thick dotted line represents the conditional variances from the SPARCH model. The fitted values show where each of the models fail. The normal model produces unreasonably smooth fitted values in the Philippines and Turkey. The model based on the t-distribution produces too smooth variances for Chile and the Philippines. The SPARCH model fails for Chile, Indonesia and Nigeria.

Overall, the GARCH models have difficulty in fitting the highly volatile and non-normal returns in the emerging equity markets. Even when non-normalities are explicitly allowed for in the estimation (t-distribution and SPARCH), the diagnostics reveal that the specifications are almost always rejected. We now explore two different routes: building a multivariate framework to allow for crosscountry effects and incorporating asymmetries into the variance process. First, we will explore the asymmetric GARCH specification.

\section{A.3 Asymmetric GARCH estimation}

Results for the asymmetric GARCH models are presented in Table A3. The parameter $\gamma_{i}$ allows for asymmetry. The test for asymmetry is whether this parameter is two standard errors from zero. In general, the sign and magnitude of this parameter is not that sensitive to the distribution used in the GARCH estimation. As such, we will concentrate our discussion on the normal model or SPARCH model.

In 11 of 19 countries (no model converged for Turkey), the coefficient is negative indicating that volatility is lower in negative returns market. In 9 of these 11 countries, the parameter is significantly less than zero. In contrast, only 4 countries (Korea, Nigeria, Philippines, and Zimbabwe) show significantly positive coefficients.

In general, the asymmetric GARCH provides an improvement in fit for most 
of the countries in our sample. The fitted variances are presented in Figure A2. However, it is surprising that in most of the countries, negative return innovations appear to decrease variance. This is the opposite to what would be predicted based on a leverage hypothesis. 
Figure 1

\section{Korea}

\section{Integration Measures Base Model \\ World Factor Proportion Three Models}
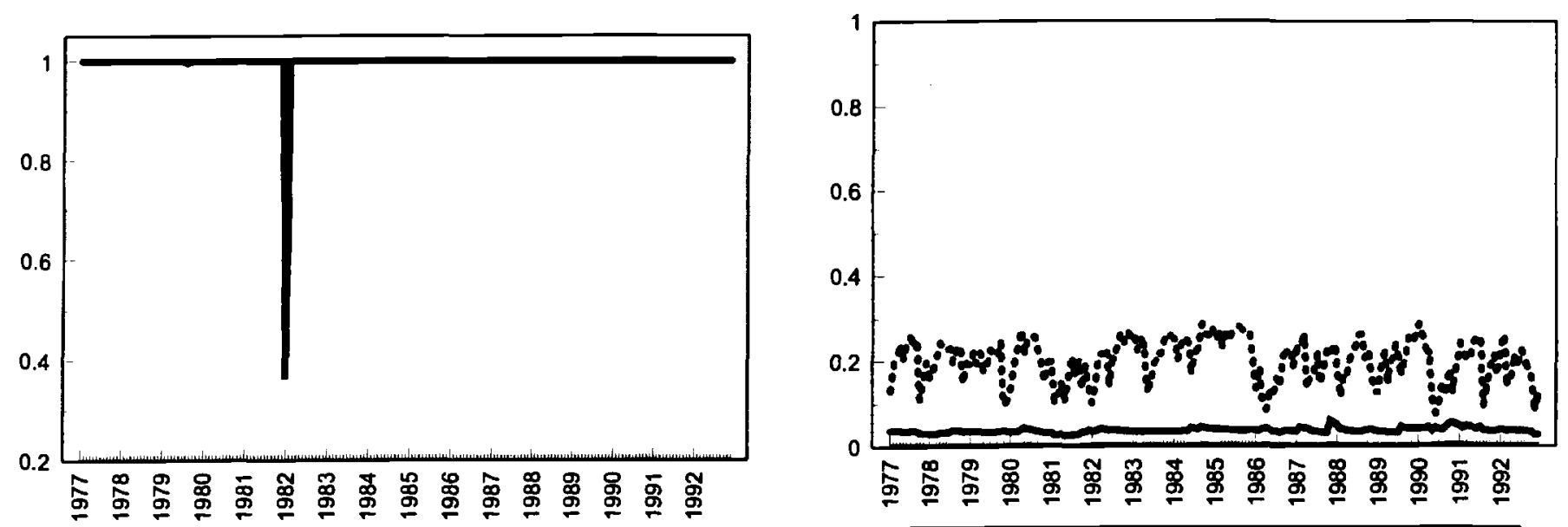

Integratipn (mean) integration (variance)

World Pro - Base World Pro - Model 1 World Pro - Model 2

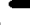

-

\section{World/Local Variance Three Models}
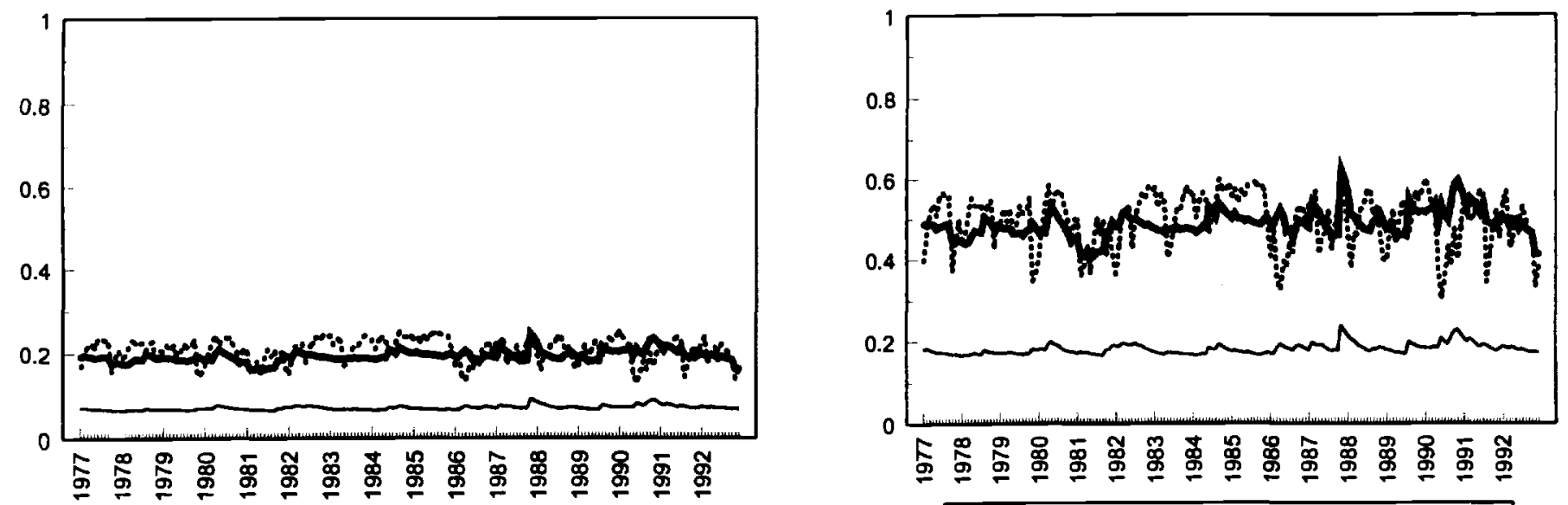

Correlation - Base Correlation - Model 1 Correlation - Model 2 - 
Figure 2

Mexico

Integration Measures

Base Model

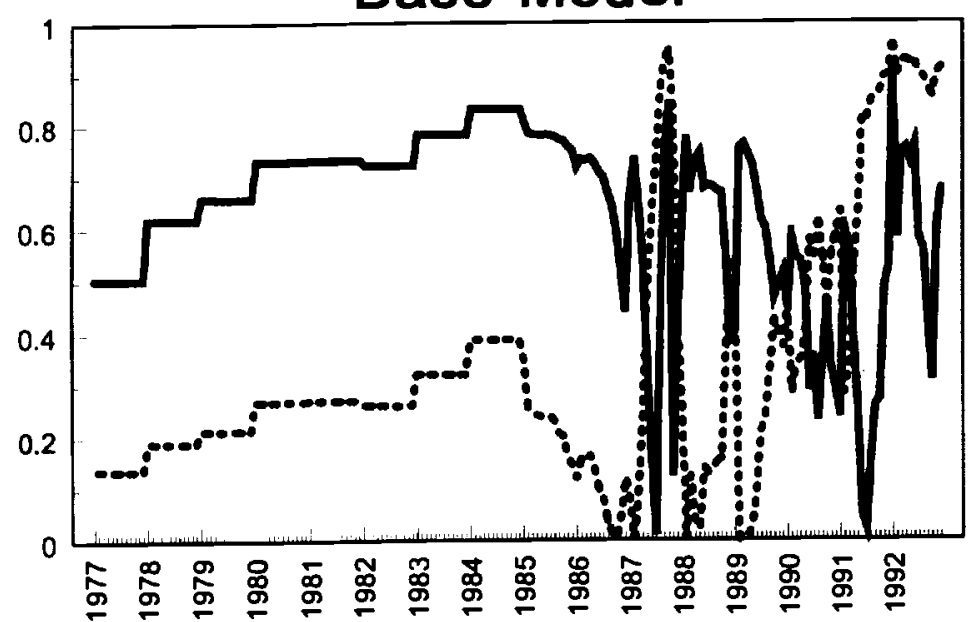

Integration (mean) Integration (variance) 1

-.
Correlation with World

Three Models

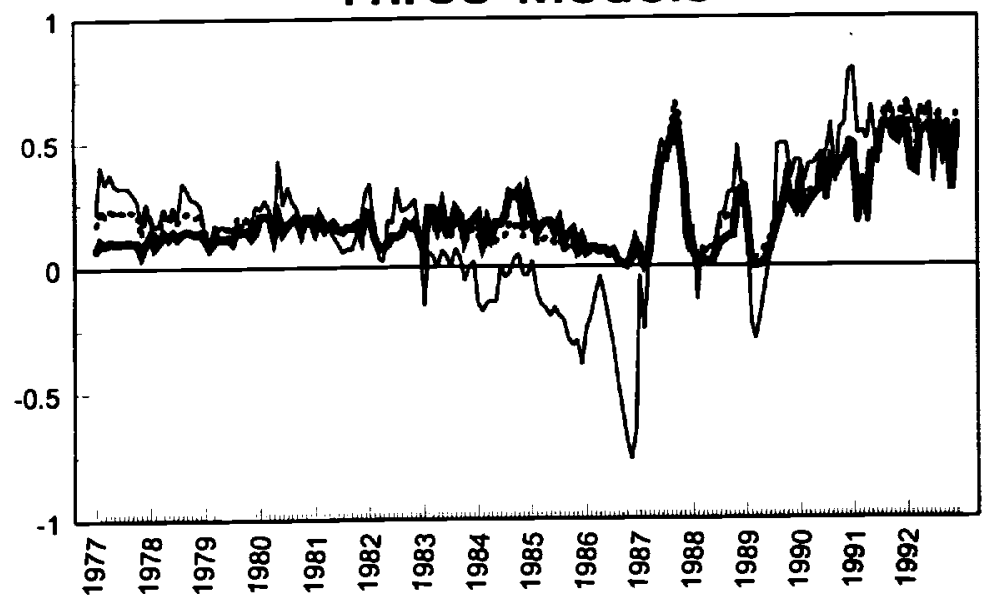

Correlation - Base Correlation - Model 1 Correlation - Model 2 -
World Factor Proportion Three Models

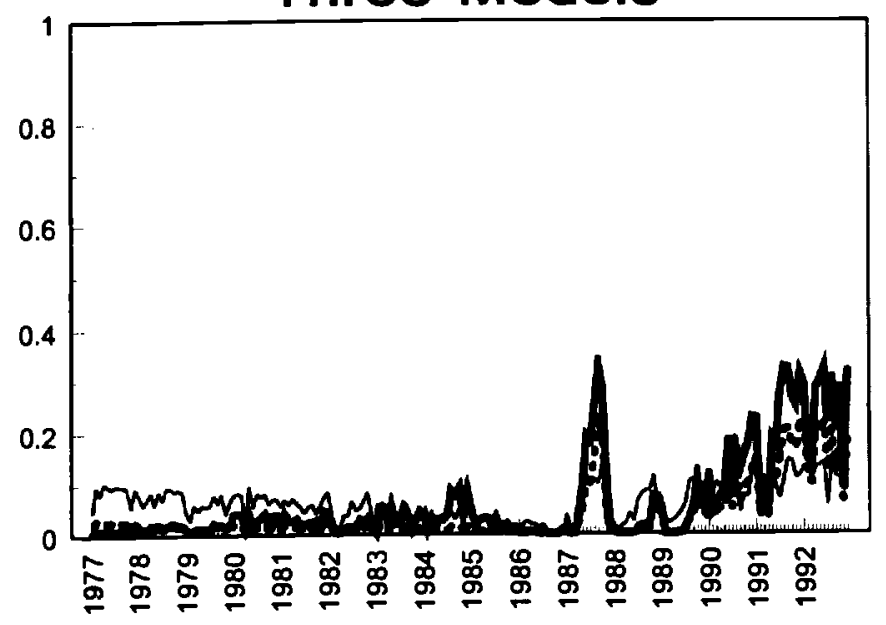

World Pro - Base World Pro - Model 1 World Pro - Model 2 -

$\bullet$
World/Local Variance

Three Models

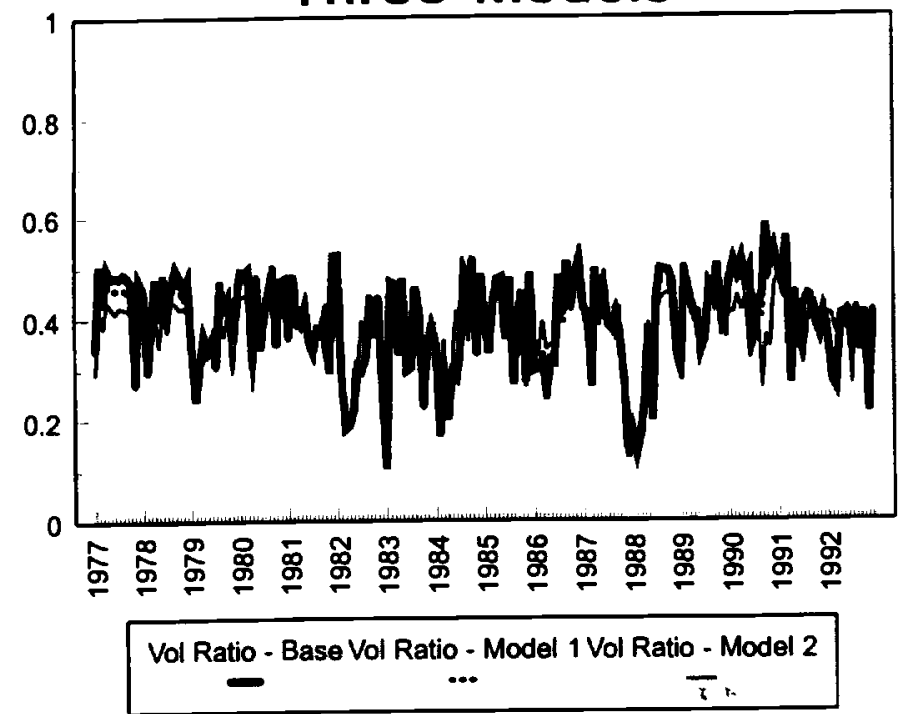


Figure 3

\section{Thailand}

Integration Measures Base Model

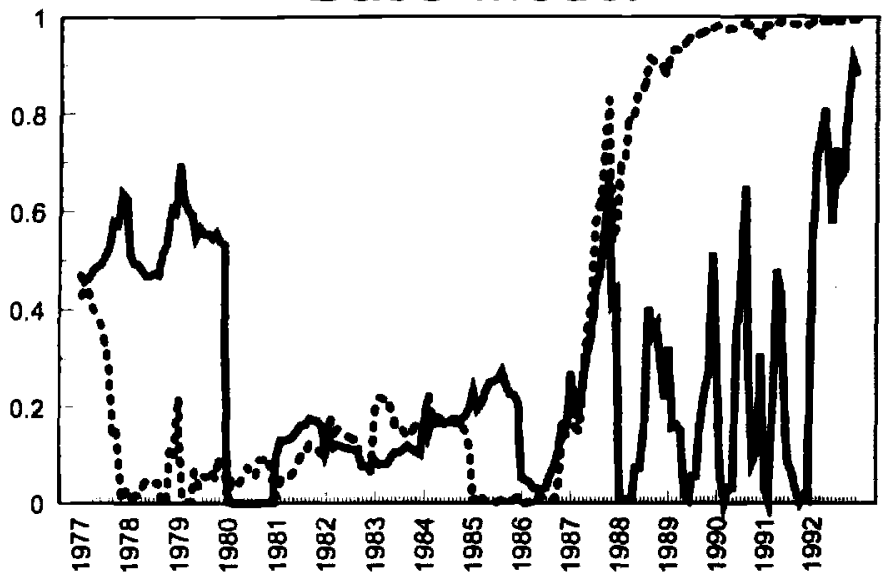

Integration (mean) Integration (variance)

\section{Correlation with World}

Three Models

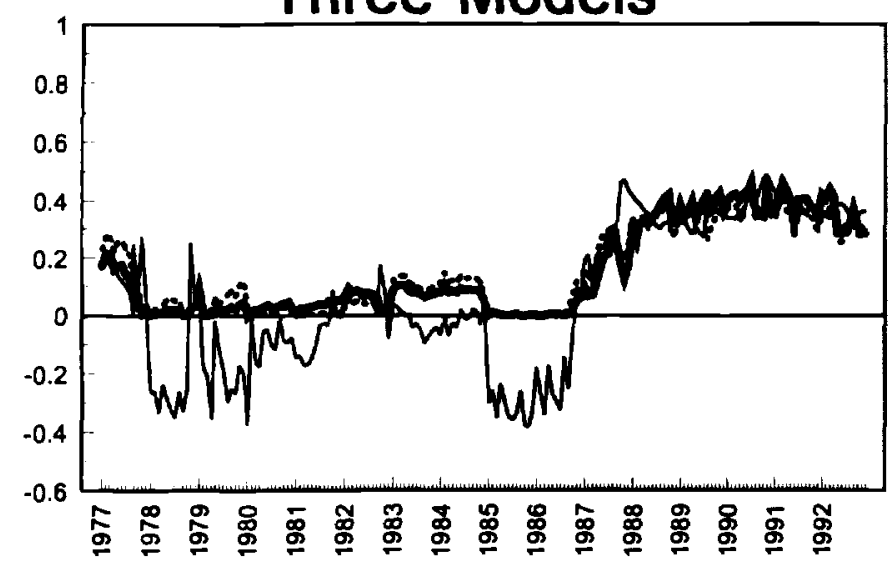

Correlation - Base Correlation - Model 1 Correlation - Model 2 -
World Factor Proportion Three Models

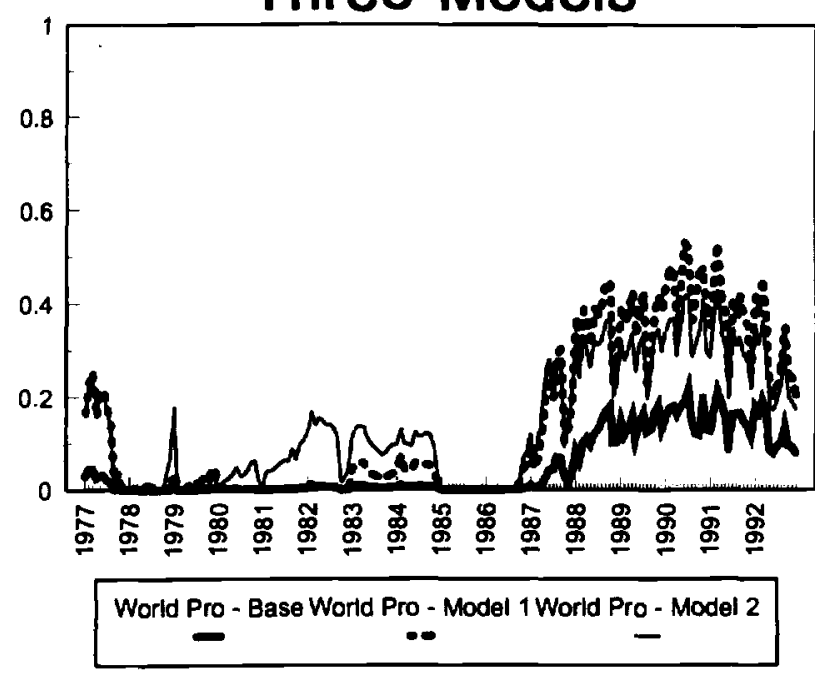

World/Local Variance Three Models

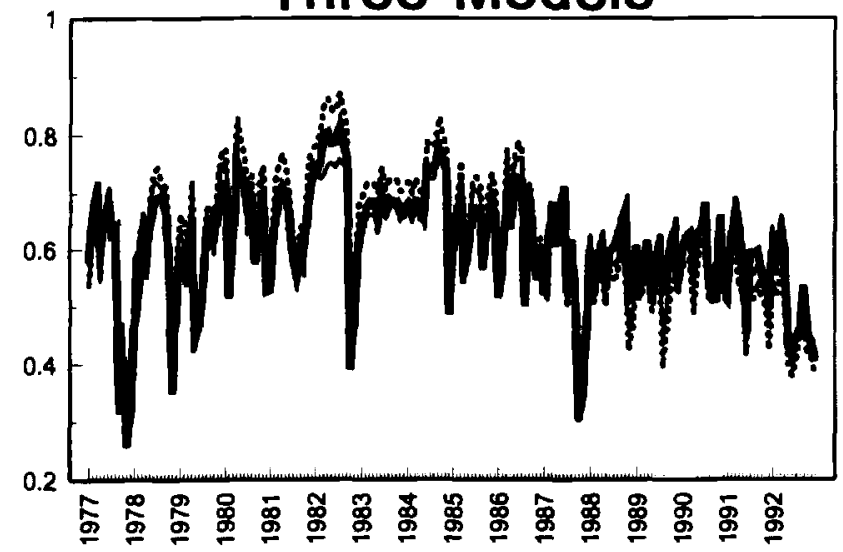

Vol Ratio - Base Vol Ratio - Model 1 Vol Ratio - Model 2 
Figure 4

\section{Capital Market Liberalizations and Volatility \\ 17 Emerging Markets}

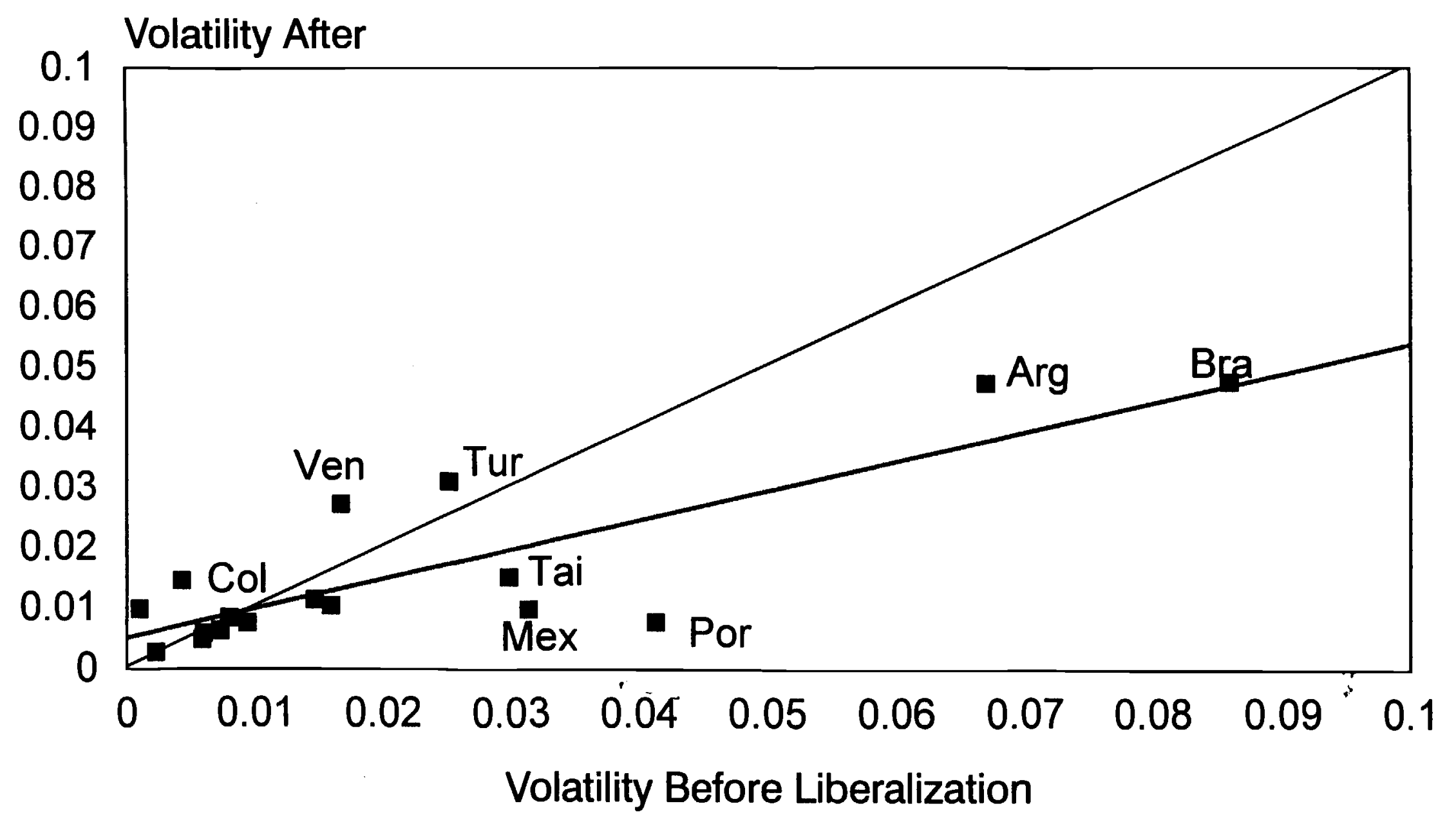

Data through December 1992 
Table 1

Distributional characteristics of emerging equity market returns

\begin{tabular}{|c|c|c|c|c|c|c|c|}
\hline \multirow[b]{2}{*}{ Country } & \multirow[b]{2}{*}{ Start } & \multicolumn{2}{|c|}{ Annualized } & \multirow[b]{2}{*}{$\rho_{1}$} & \multicolumn{2}{|c|}{ Coefficient of } & \multirow[b]{2}{*}{$\chi^{2}$} \\
\hline & & mean & std. dev. & & skewness & $\begin{array}{c}\text { excess } \\
\text { kurtosis }\end{array}$ & \\
\hline Argentina & 76.01 & 67.87 & 103.70 & 0.054 & $\begin{array}{c}1.961 \\
(0.447)\end{array}$ & $\begin{array}{c}7.225 \\
(2.589)\end{array}$ & {$[<0.001]$} \\
\hline Brazil & 76.01 & 22.10 & 60.09 & 0.029 & $\begin{array}{c}0.519 \\
(0.242)\end{array}$ & $\begin{array}{c}1.019 \\
(0.454)\end{array}$ & {$\left[\begin{array}{l}12.19 \\
{[0.002]}\end{array}\right.$} \\
\hline Chile & 76.01 & 36.67 & 39.48 & 0.169 & $\begin{array}{c}0.931 \\
(0.476)\end{array}$ & $\begin{array}{c}3.126 \\
(2.131)\end{array}$ & $\begin{array}{c}5.333 \\
{[0.070]}\end{array}$ \\
\hline Colombia & 85.01 & 43.64 & 31.98 & 0.489 & $\begin{array}{c}1.709 \\
(0.325)\end{array}$ & $\begin{array}{c}4.050 \\
(2.039)\end{array}$ & {$\left[\begin{array}{c}36.43 \\
0.001]\end{array}\right.$} \\
\hline Greece & 76.01 & 7.47 & 36.13 & 0.132 & $\begin{array}{c}1.833 \\
(0.443)\end{array}$ & $\begin{array}{c}7.327 \\
(2.114)\end{array}$ & {$[<0.001]$} \\
\hline India & 76.01 & 20.20 & 27.16 & 0.079 & $\begin{array}{c}0.662 \\
(0.289)\end{array}$ & $\begin{array}{c}2.242 \\
(0.891)\end{array}$ & $\begin{array}{c}7.952 \\
{[0.019]}\end{array}$ \\
\hline Indonesia & 90.01 & -12.22 & 32.10 & 0.285 & $\begin{array}{c}0.120 \\
(0.262)\end{array}$ & $\begin{array}{r}-0.2190 \\
(0.447)\end{array}$ & $\begin{array}{c}0.5220 \\
{[0.770]}\end{array}$ \\
\hline Jordan & 79.01 & 10.75 & 17.84 & 0.000 & $\begin{array}{c}0.452 \\
(0.212)\end{array}$ & $\begin{array}{c}0.9167 \\
(0.401)\end{array}$ & $\begin{array}{c}7.848 \\
{[0.020]}\end{array}$ \\
\hline Korea & 76.01 & 21.26 & 32.26 & -0.001 & $\begin{array}{c}0.991 \\
(0.301)\end{array}$ & $\begin{array}{l}1.961 \\
(1.280)\end{array}$ & {$[<0.001]$} \\
\hline Malaysia & 85.01 & 13.84 & 26.21 & 0.052 & $\begin{array}{c}-0.639 \\
(0.519)\end{array}$ & $\begin{array}{c}2.146 \\
(1.478)\end{array}$ & $\begin{array}{r}2.129 \\
{[0.345]}\end{array}$ \\
\hline Mexico & 76.01 & 30.39 & 44.45 & 0.248 & $\begin{array}{c}-0.826 \\
(0.444)\end{array}$ & $\begin{array}{c}3.694 \\
(1.300)\end{array}$ & $\begin{array}{r}8.205 \\
{[0.017]}\end{array}$ \\
\hline Nigeria & 85.01 & 2.70 & 36.31 & 0.085 & $\begin{array}{c}-1.771 \\
(1.062)\end{array}$ & $\begin{array}{r}11.230 \\
(3.537)\end{array}$ & $\begin{array}{l}10.250 \\
{[0.006]}\end{array}$ \\
\hline Pakistan & 85.01 & 21.53 & 23.08 & 0.250 & $\begin{array}{c}2.093 \\
(0.633)\end{array}$ & $\begin{array}{c}9.585 \\
(4.342)\end{array}$ & $\begin{array}{l}11.750 \\
{[0.003]}\end{array}$ \\
\hline Philippines & 85.01 & 45.31 & 37.99 & 0.338 & $\begin{array}{c}0.447 \\
(0.420)\end{array}$ & $\begin{array}{c}2.122 \\
(0.808)\end{array}$ & $\begin{array}{c}7.011 \\
{[0.030]}\end{array}$ \\
\hline Portugal & 86.02 & 34.57 & 49.92 & 0.287 & $\begin{array}{c}1.578 \\
(0.575)\end{array}$ & $\begin{array}{c}5.079 \\
(2.326)\end{array}$ & $\begin{array}{c}7.757 \\
{[0.020]}\end{array}$ \\
\hline Taiwan & 85.01 & 34.02 & 52.62 & 0.074 & $\begin{array}{l}0.244 \\
(0.283)\end{array}$ & $\begin{array}{c}0.959 \\
(0.658)\end{array}$ & $\begin{array}{r}2.130 \\
{[0.344]}\end{array}$ \\
\hline Thailand & 76.01 & 22.33 & 25.69 & 0.114 & $\begin{array}{c}-0.0962 \\
(0.505)\end{array}$ & $\begin{array}{c}3.267 \\
(1.352)\end{array}$ & $\begin{array}{l}11.340 \\
{[0.003]}\end{array}$ \\
\hline Turkey & 87.01 & 37.74 & 73.74 & 0.232 & $\begin{array}{c}1.045 \\
(0.257)\end{array}$ & $\begin{array}{c}0.928 \\
(0.743)\end{array}$ & {$\left[\begin{array}{l}43.070 \\
{[<0.001]}\end{array}\right]$} \\
\hline Venezuela & 85.01 & 32.19 & 47.06 & 0.267 & $\begin{array}{c}0.107 \\
(0.632)\end{array}$ & $\begin{array}{c}3.093 \\
(1.005)\end{array}$ & $\begin{array}{l}12.140 \\
{[0.002]}\end{array}$ \\
\hline Zimbabwe & 76.01 & 7.77 & 34.09 & 0.138 & $\begin{array}{c}0.284 \\
(0.406) \\
\end{array}$ & $\begin{array}{c}1.892 \\
(1.280)\end{array}$ & $\begin{array}{r}4.008 \\
{[0.135]}\end{array}$ \\
\hline
\end{tabular}

All monthly returns from International Finance Corporation and calculated in U.S. dollars. The sample ends in December 1992. Heteroskedasticity-consistent standard errors in parentheses and p-values in brackets. The coefficients of skewness and excess kurtosis are jointly estimated along with the mean and variance. The p-value from a Wald test of the null hypothesis that the coefficients are zero is reported. 
Table 2

Univariate, segmented variance model selection

The following model is estimated:

$$
\begin{aligned}
r_{i, t} & =\mathbf{X}_{i, t-1}^{\prime} \delta_{i}+\epsilon_{i, t} \\
\epsilon_{i, t} & =\sigma_{i, t} z_{i, t} \\
\sigma_{i, t}^{2} & =w_{i}+\alpha_{i} \sigma_{i, t-1}^{2}+\beta_{i} \epsilon_{i, t-1}^{2}
\end{aligned}
$$

where $r_{i, t}$ represents the return on the national equity index of country $i, \mathbf{X}_{i, t-1}$ represents a set of local information variables that affect the conditional mean, $\sigma_{t}^{2}$ is the conditional variance and $z_{i, t}$ are the standardized residuals formed by dividing the residuals, $\epsilon_{i, t}$ by the volatility, $\sigma_{i t}$. Three different distributional assumptions are used on the residuals: normal, $t$ distribution and SPARCH. The SPARCH involves a mixture of normal distributions. The asymmetric model has an additional term in the variance equation which allows for asymmetric responses to negative and positive return shocks.

\begin{tabular}{r|r|r}
\hline Country & $\begin{array}{r}\text { Variance } \\
\text { model }\end{array}$ & Asymmetric \\
\hline Argentina & SPARCH & No \\
Brazil & SPARCH & Yes \\
Chile & Normal & Yes \\
Colombia & SPARCH & Yes \\
Greece & SPARCH & Yes \\
India & SPARCH & Yes \\
Indonesia & Normal & Yes \\
Jordan & T & Yes \\
Korea & SPARCH & Yes \\
Malaysia & T & Yes \\
Mexico & Normal & Yes \\
Nigeria & Normal & No \\
Pakistan & SPARCH & Yes \\
Philippines & SPARCH & No \\
Portugal & Normal & Yes \\
Taiwan & Normal & Yes \\
Thailand & SPARCH & Yes \\
Turkey & SPARCH & No \\
Venezuela & SPARCH & No \\
Zimbabwe & Yes \\
\hline
\end{tabular}

All monthly returns from International Finance Corporation and calculated in U.S. dollars. The sample ends in December 1992.

$$
\because
$$


Table 3

World factor model: Parameters and diagnostics

Estimation consists of two steps. First, the world variance dynamics are given by:

$$
\begin{aligned}
& r_{w, t}=\delta_{w}^{\prime} \mathbf{X}_{t-1}+\epsilon_{w, t} \\
& \sigma_{w, t}^{2}=c_{w}+\alpha_{w} \sigma_{w, t-1}^{2}+\beta_{w} \epsilon_{w, t-1}^{2}
\end{aligned}
$$

where $\mathbf{X}_{t-1}$ represents a set of world information variables which include: a constant, the lagged world market dividend yield in excess of the 30-day Eurodollar rate, the lagged default spread (Moody's Baa minus Aaa bond yields), the lagged change in the term structure spread (U.S. 10-year bond yield minus 3-month U.S. bill), and the lagged change in the 30-day Eurodollar rate. The the mean return in country $i$ is a function of both world and local information:

$$
r_{i, t}=\theta_{i, t-1} \kappa_{i} \delta_{w}^{\prime} \mathbf{X}_{t-1}+\left(1-\theta_{i, t-1}\right)\left(\delta_{i}^{\prime} \mathbf{X}_{i, t-1}\right)+\epsilon_{i, t}
$$

where $\mathbf{X}_{i, t-1}$ represents the local information variables: a constant, the lagged equity return, the lagged exchange rate change, and the lagged dividend yield. $\theta_{i, t-1}$ is a function of local information and is restricted to the $[0,1]$ range. We allow the shocks to the local returns to be driven by both world and local shocks:

$$
\epsilon_{i, t}=\xi_{i} \psi_{i, t-1} \epsilon_{w, t}+e_{i, t}
$$

\begin{tabular}{|c|c|c|c|c|c|c|c|c|c|}
\hline \multirow[b]{3}{*}{ Country } & \multirow[b]{3}{*}{$\kappa_{i}$} & \multirow[b]{3}{*}{$\xi_{i}$} & \multicolumn{3}{|c|}{ Wald tests } & \multicolumn{2}{|c|}{ LR tests } & \multirow{2}{*}{\multicolumn{2}{|c|}{ Residual diagnostics }} \\
\hline & & & \multirow[t]{2}{*}{$\kappa_{i}=\xi_{i}$} & \multirow[t]{2}{*}{$\psi_{i t}=\theta_{i t}$} & \multirow{2}{*}{$\begin{aligned} \kappa_{i} & =\xi_{i} \\
\psi_{i t} & =\theta_{i t}\end{aligned}$} & \multirow{2}{*}{$f_{i}=\xi_{i}$} & \multirow{2}{*}{$\begin{array}{c}f_{i}=\xi_{i} \\
g_{i}=k_{i}=0\end{array}$} & & \\
\hline & & & & & & & & mean & variance \\
\hline Argentina & $\begin{array}{c}0.739 \\
(0.054)\end{array}$ & $\begin{array}{c}0.288 \\
(0.140)\end{array}$ & $\begin{array}{l}8.060 \\
{[0.005]}\end{array}$ & {$\left[\begin{array}{l}>0.000 \\
<0.00\end{array}\right]$} & {$[<1000]$} & 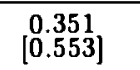 & $\begin{array}{l}12.541 \\
{[0.014]}\end{array}$ & $\begin{array}{c}7.56 \\
{[0.272]}\end{array}$ & $\begin{array}{r}9.22 \\
{[0.162]}\end{array}$ \\
\hline Brazil & $\begin{array}{l}0.781 \\
(1.096)\end{array}$ & $\begin{array}{c}0.358 \\
(0.337)\end{array}$ & {$[0.148$} & $\begin{array}{c}9.544 \\
{[0.023]}\end{array}$ & $\begin{array}{l}10.402 \\
{[0.034]}\end{array}$ & {$\left[\begin{array}{c}0.081 \\
{[0.776]}\end{array}\right.$} & $\begin{array}{c}9.048 \\
{[0.060]}\end{array}$ & {$\left[\begin{array}{c}1.81 \\
{[0.937]}\end{array}\right.$} & $\begin{array}{r}4.75 \\
{[0.576]}\end{array}$ \\
\hline Chile & $\begin{array}{c}-0.504 \\
(0.174)\end{array}$ & $\begin{array}{c}0.070 \\
(0.496)\end{array}$ & $\begin{array}{c}9.228 \\
{[0.002]}\end{array}$ & 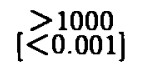 & {$\left[\begin{array}{l}>0.001] \\
<0.001\end{array}\right.$} & $\begin{array}{c}0.135 \\
{[0.713]}\end{array}$ & $\begin{array}{c}2.895 \\
{[0.576]}\end{array}$ & {$[0.017]$} & $\begin{array}{r}7.12 \\
{[0.310]}\end{array}$ \\
\hline Colombia & $\begin{array}{l}2.286 \\
(1.045)\end{array}$ & $\begin{array}{c}0.536 \\
(0.446)\end{array}$ & {$\left[\begin{array}{l}2.737 \\
{[0.096]}\end{array}\right.$} & {$\left[\begin{array}{l}24.799 \\
<0.001\end{array}\right]$} & {$[\stackrel{28.485}{<0.001]}]$} & {$\left[\begin{array}{l}35.547 \\
{[<0.001]}\end{array}\right.$} & {$[<6.389$} & $\begin{array}{c}3.13 \\
{[0.792]}\end{array}$ & $\begin{array}{r}6.00 \\
{[0.42]}\end{array}$ \\
\hline Greece & $\begin{array}{c}0.501 \\
(0.164)\end{array}$ & $\begin{array}{c}1.073 \\
(0.245)\end{array}$ & $\begin{array}{c}3.649 \\
{[0.056]}\end{array}$ & {$\left[\begin{array}{l}\geq 0.001 \\
<0.00\end{array}\right]$} & {$\left[\begin{array}{l}> \\
<0.001\end{array}\right]$} & $\begin{array}{c}6.994 \\
{[0.008]}\end{array}$ & {$[0.017]^{c}$} & $\begin{array}{c}4.54 \\
{[0.604]}\end{array}$ & $\begin{array}{r}3.23 \\
{[0.779]}\end{array}$ \\
\hline India & $\begin{array}{c}4.121 \\
(4.897)\end{array}$ & $\begin{array}{c}0.314 \\
(0.118)\end{array}$ & {$\left[\begin{array}{l}0.601 \\
{[0.438]}\end{array}\right.$} & $\begin{array}{c}2.655 \\
{[0.448]}\end{array}$ & {$[<<0.001]$} & {$[<0.001]$} & {$\left[\begin{array}{l}46.389^{c} \\
{[<0.001}\end{array}\right]$} & {$[0.118]$} & $\begin{array}{r}4.81 \\
{[0.568]}\end{array}$ \\
\hline Indonesia $^{a}$ & & & & & & & & & \\
\hline Jordan & $\begin{array}{c}-0.308 \\
(0.309)\end{array}$ & $\begin{array}{c}0.319 \\
(0.175)\end{array}$ & $\begin{array}{c}3.292 \\
{[0.069]}\end{array}$ & {$[<0.001]$} & {$[<0.001]$} & $\begin{array}{c}5.708 \\
{[0.017]}\end{array}$ & $\begin{array}{c}7.693 \\
{[0.103]}\end{array}$ & $\begin{array}{c}8.59 \\
{[0.198]}\end{array}$ & $\begin{array}{r}5.61 \\
{[0.468]}\end{array}$ \\
\hline Korea $^{b}$ & $\begin{array}{c}0.858 \\
(0.126)\end{array}$ & $\begin{array}{c}0.397 \\
(0.126)\end{array}$ & $\begin{array}{c}6.459 \\
{[0.011]}\end{array}$ & {$\left[\begin{array}{l}>0.001] \\
{[0.000}\end{array}\right.$} & {$\left[\begin{array}{l}>1000 \\
<0.001]\end{array}\right.$} & {$\left[\begin{array}{c}9.924 \\
{[0.001]}\end{array}\right]$} & - & $\begin{array}{c}9.93 \\
{[0.128]}\end{array}$ & $\begin{array}{r}6.43 \\
{[0.468]}\end{array}$ \\
\hline Malaysia $^{b}$ & $\begin{array}{c}0.324 \\
(0.684)\end{array}$ & $\begin{array}{c}1.142 \\
(0.264)\end{array}$ & $\begin{array}{l}1.350 \\
{[0.245]}\end{array}$ & {$[<0.001]$} & {$[<0.236$} & {$[0.212$} & : & {$\left[\begin{array}{l}10.01 \\
{[0.124]}\end{array}\right.$} & $\begin{array}{r}4.63 \\
{[0.591]}\end{array}$ \\
\hline Mexico & $\begin{array}{c}-0.183 \\
(3.229)\end{array}$ & $\begin{array}{c}1.529 \\
(0.544)\end{array}$ & $\begin{array}{c}0.270 \\
{[0.603]}\end{array}$ & $\begin{array}{l}11.350 \\
{[0.011]}\end{array}$ & $\begin{array}{l}13.072 \\
{[0.011]}\end{array}$ & {$[0.179]$} & $\begin{array}{c}6.273 \\
{[0.180]}\end{array}$ & $\begin{array}{c}3.24 \\
{[0.778]}\end{array}$ & $\begin{array}{r}1.40 \\
{[0.966]}\end{array}$ \\
\hline Nigeria ${ }^{b, d}$ & $\begin{array}{c}0.257 \\
(0.668) \\
\end{array}$ & $\begin{array}{c}0.406 \\
(1.939) \\
\end{array}$ & $\begin{array}{c}0.005 \\
{[0.943]} \\
\end{array}$ & {$\left[\begin{array}{l}21.371 \\
{[<0.001]}\end{array}\right.$} & {$[<0.001]$} & $\begin{array}{c}8.033 \\
{[0.005]}\end{array}$ & - & $\begin{array}{r}8.04 \\
{[0.235]} \\
\end{array}$ & $\begin{array}{r}5.41 \\
{[0.492]} \\
\end{array}$ \\
\hline
\end{tabular}

where $\xi_{i}$ is a scale parameter and $\psi_{i, t-1}$ represents the importance of the world shock which is also restricted to fall in the [0,1] range. 


\begin{tabular}{|c|c|c|c|c|c|c|c|c|c|}
\hline \multirow[b]{3}{*}{ Country } & \multirow[b]{3}{*}{$\kappa_{i}$} & \multirow[b]{3}{*}{$\xi_{i}$} & \multicolumn{3}{|c|}{ Wald tests } & \multicolumn{2}{|c|}{ LR tests } & \multirow{2}{*}{\multicolumn{2}{|c|}{ Residual diagnostics }} \\
\hline & & & $\kappa_{i}=\xi_{i}$ & $\psi_{i t}=\theta_{i t}$ & $\kappa_{i}=\xi_{i}$ & $f_{i}=\xi_{i}$ & $f_{i}=\xi_{i}$ & & \\
\hline & & & & & $\psi_{i t}=\theta_{i t}$ & & $g_{i}=k_{i}=0$ & mean & variance \\
\hline Pakistan $^{6}$ & $\begin{array}{l}0.609 \\
(0.242)\end{array}$ & $\begin{array}{c}2.159 \\
(0.287)\end{array}$ & $\begin{array}{l}14.990 \\
{[0.001]}\end{array}$ & {$[<0.001]$} & {$[<1000$} & {$\left[\begin{array}{c}20.347 \\
{[<0.001]}\end{array}\right.$} & - & $\begin{array}{c}5.85 \\
{[0.439]}\end{array}$ & $\begin{array}{r}6.04 \\
{[0.419]}\end{array}$ \\
\hline Philippines $^{b, d}$ & $>1000$ & $>1000$ & {$[<1000$} & {$[<0.001]$} & {$[<0.001]$} & - & & $\begin{array}{c}5.17 \\
{[0.522]}\end{array}$ & $\begin{array}{r}3.61 \\
{[0.419]}\end{array}$ \\
\hline Portugal $^{b}$ & $>1000$ & $\begin{array}{c}2.970 \\
(0.190)\end{array}$ & {$[<0.001]$} & {$\left[\begin{array}{l}>0.001] \\
{[<00}\end{array}\right.$} & {$[<0.001]$} & $-e$ & - & {$\left[\begin{array}{c}4.06 \\
{[0.668]}\end{array}\right.$} & $\begin{array}{r}13.49 \\
{[0.036]}\end{array}$ \\
\hline Taiwan $^{d}$ & $(0.131)$ & $\begin{array}{c}0.546 \\
(0.268)\end{array}$ & {$\left[\begin{array}{l}14.598 \\
<<0.001]\end{array}\right]$} & {$\left[\begin{array}{l}>1000 \\
{[<0.001]}\end{array}\right.$} & {$[<0.001]$} & {$\left[\begin{array}{l}20.278^{c} \\
{[<0.001]}\end{array}\right.$} & - & {$\left[\begin{array}{c}5.78 \\
{[0.447]}\end{array}\right.$} & $\begin{array}{r}4.04 \\
{[0.672]}\end{array}$ \\
\hline Thailand & $\begin{array}{c}5.482 \\
(2.562)\end{array}$ & $\begin{array}{l}0.690 \\
(0.319)\end{array}$ & $\begin{array}{c}3.811 \\
{[0.051]}\end{array}$ & {$\left[\begin{array}{l}6.179 \\
{[0.103]}\end{array}\right]$} & {$[<0.001]$} & {$\left[\begin{array}{c}4.89 \\
{[0.030]}\end{array}\right.$} & {$\left[\begin{array}{c}7.79 \\
{[0.001]}\end{array}\right]$} & {$[0.274]$} & $\begin{array}{r}3.78 \\
{[0.707]}\end{array}$ \\
\hline Turkey & $\begin{array}{l}-8.157 \\
(0.014)\end{array}$ & $\begin{array}{l}-1.696 \\
(0.034)\end{array}$ & {$[<0.001]$} & {$[<0.001]$} & {$[<0.001]$} & {$\left[\begin{array}{l}1.466 \\
{[0.226]}\end{array}\right.$} & $\begin{array}{l}16.387 \\
{[0.003]}\end{array}$ & {$[0.900]$} & $\begin{array}{r}10.48 \\
{[0.106]}\end{array}$ \\
\hline Venezuela & $\begin{array}{c}3.804 \\
(0.033)\end{array}$ & 399.82 & {$\left[\begin{array}{l}>1000 \\
{[0.001]}\end{array}\right.$} & {$[<0.001]$} & {$[<1000$} & $\begin{array}{c}2.869 \\
{[0.090]}\end{array}$ & $\begin{array}{l}8.791 \\
{[0.067]}\end{array}$ & {$\left[\begin{array}{c}5.79 \\
{[0.446]}\end{array}\right.$} & {$\left[\begin{array}{r}6.64 \\
{[0.355]}\end{array}\right.$} \\
\hline Zimbabwe & $\begin{array}{r}-6.827 \\
(0.162) \\
\end{array}$ & $\begin{array}{c}0.625 \\
(0.168) \\
\end{array}$ & {$\left[\begin{array}{l}34.158 \\
{[<0.001]}\end{array}\right.$} & {$[<0.001]$} & {$\left[\begin{array}{l}>1000 \\
{[<0.001]}\end{array}\right]$} & {$\left[\begin{array}{c}36.188 \\
{[<0.001]}\end{array}\right]$} & $\begin{array}{l}39.129 \\
{[<0.001]}\end{array}$ & $\begin{array}{c}8.63 \\
{[0.195]} \\
\end{array}$ & $\begin{array}{r}2.98 \\
{[0.810]} \\
\end{array}$ \\
\hline
\end{tabular}

All monthly returns from International Finance Corporation and calculated in U.S. dollars. The sample ends in December 1992.

${ }^{a}$ Indonesia had too few data to estimate any of the models.

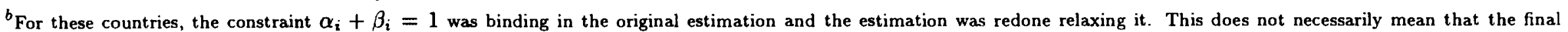
parameters are characterized by $\alpha_{i}+\beta_{i}>1$.

${ }^{c}$ The estimation procedure failed to fully converge, but the gradients at the "optimum" are smaller than 0.000001 .

${ }^{d}$ Particularly ill-behaved estimation, may not have found global. There are many different local optima.

${ }^{e}$ No convergence could be reached 
Table 4

Correlation, integration and the importance of world factors

$\theta_{i, t-1}$ represents the importance of world information in the country's conditional mean equation. It falls in the $[0,1]$ range. $\psi_{i, t-1}$ represents the importance of world information in the country's conditional variance equation. It also falls in the $[0,1]$ range. The world market correlation in our model is given by:

$$
\rho_{i t}=\xi_{i} \psi_{i, t-1} \frac{\sigma_{w, t}}{\sigma_{i, t}}
$$

The proportion of variance accounted for by world factors is:

$$
V R_{i, t}=\frac{\xi_{i} \psi_{i, t-1} \sigma_{i w, t}}{\sigma_{i, t}^{2}}
$$

\begin{tabular}{|c|c|c|c|c|c|c|c|c|}
\hline \multirow[b]{2}{*}{ Country } & \multicolumn{3}{|c|}{$\begin{array}{l}\text { Mean proportion of variance } \\
\text { due to world factors, } \overline{V R}_{i}\end{array}$} & \multicolumn{2}{|c|}{ Integration from } & \multicolumn{3}{|c|}{$\begin{array}{l}\text { Correlation, } \bar{\rho}_{i t} \\
\quad \text { with world }\end{array}$} \\
\hline & Full sample & Post-crash & Post-liberal & $\frac{\text { mean }}{\bar{\theta}_{i t}}$ & $\frac{\text { variance }}{\bar{\psi}_{i t}}$ & Full sample & Post-crash & Post-liberal \\
\hline Argentina & 0.002 & 0.003 & 0.003 & 0.965 & 0.949 & 0.048 & 0.050 & 0.051 \\
\hline Brazil & 0.008 & 0.004 & 0.004 & 0.968 & 0.891 & 0.082 & 0.061 & 0.065 \\
\hline Chile & 0.001 & 0.001 & 0.001 & 0.969 & 1.000 & 0.031 & 0.033 & 0.033 \\
\hline Colombia & 0.016 & 0.020 & 0.035 & 0.737 & 0.360 & 0.101 & 0.121 & 0.172 \\
\hline Greece & 0.067 & 0.114 & 0.113 & 1.000 & 0.533 & 0.218 & 0.327 & 0.325 \\
\hline India & 0.029 & 0.019 & 0.012 & 0.327 & 0.809 & 0.155 & 0.120 & 0.109 \\
\hline Indonesia $^{a}$ & & & & & & & & \\
\hline Jordan & 0.038 & 0.063 & 0.064 & 0.998 & 0.606 & 0.166 & 0.241 & 0.244 \\
\hline Korea $^{b}$ & 0.038 & 0.040 & 0.035 & 0.997 & 1.000 & 0.194 & 0.201 & 0.186 \\
\hline Malaysia $^{b}$ & 0.295 & 0.266 & 0.237 & 0.891 & 0.718 & 0.497 & 0.458 & 0.415 \\
\hline Mexico & 0.061 & 0.123 & 0.189 & 0.633 & 0.336 & 0.198 & 0.298 & 0.418 \\
\hline Nigeria $^{b, d}$ & 0.002 & 0.003 & - & 0.601 & 0.123 & 0.032 & 0.031 & - \\
\hline Pakistan ${ }^{b}$ & 0.083 & 0.112 & 0.286 & 1.000 & 0.176 & 0.182 & 0.234 & 0.511 \\
\hline Philippines $^{b, d}$ & 0.133 & 0.160 & 0.017 & 0.000 & 0.000 & 0.275 & 0.304 & 0.087 \\
\hline Portugal ${ }^{b}$ & 0.276 & 0.300 & 0.313 & 0.000 & 0.278 & 0.437 & 0.463 & 0.476 \\
\hline Taiwan $^{d}$ & 0.029 & 0.025 & 0.032 & 0.991 & 0.870 & 0.156 & 0.141 & 0.163 \\
\hline Thailand & 0.058 & 0.137 & 0.146 & 0.264 & 0.389 & 0.155 & 0.364 & 0.379 \\
\hline Turkey & 0.045 & - & 0.020 & 0.992 & 0.399 & -0.177 & - & -0.116 \\
\hline Venezuela & 0.015 & 0.021 & 0.038 & 0.995 & 0.000 & 0.069 & 0.089 & 0.155 \\
\hline Zimbabwe & 0.036 & 0.027 & - & 0.971 & 0.623 & 0.165 & 0.136 & - \\
\hline
\end{tabular}

All monthly returns from International Finance Corporation and calculated in U.S. dollars. The sample ends in December 1992.

${ }^{a}$ Indonesia had too few data to estimate any of the models.

${ }^{b}$ For these countries, the constraint $\alpha_{i}+\beta_{i}=1$ was binding in the original estimation and the estimation was redone relaxing it. This does not necessarily mean that the final parameters are characterized by $\alpha_{i}+\beta_{i}>1$.

"The estimation procedure failed to fully converge, but the gradients at the "optimum"are smaller than 0.000001 .

${ }^{d}$ Particularly ill-behaved estimation, may not have found global. There are many different local optima.

${ }^{e}$ No convergence could be reached.

$$
+2
$$


Table 5

Summary statistics for cross-sectional analysis

\begin{tabular}{|c|c|c|c|c|c|c|c|c|c|c|c|}
\hline \multirow[b]{2}{*}{ Country } & \multirow{2}{*}{$\begin{array}{l}\text { Total } \\
\text { fitted }\end{array}$} & \multirow{2}{*}{$\begin{array}{c}\text { Obs. used } \\
\text { in regression }\end{array}$} & \multicolumn{2}{|c|}{ Mean cross-sectional } & \multirow{2}{*}{$\begin{array}{l}\text { Number of } \\
\text { firms }\end{array}$} & \multirow{2}{*}{$\begin{array}{c}\text { Concentration } \\
\text { factor }\end{array}$} & \multirow{2}{*}{$\begin{array}{l}\text { Country } \\
\text { credit } \\
\text { rating }\end{array}$} & \multirow{2}{*}{$\begin{array}{c}\text { Trade/ } \\
\text { GDP }\end{array}$} & \multirow{2}{*}{$\begin{array}{c}\text { Market } \\
\text { capitalization } \\
\text { GDP }\end{array}$} & \multirow[b]{2}{*}{ Turnover } & \multirow{2}{*}{$\begin{array}{c}\text { Foreign } \\
\text { exchange } \\
\text { volatility }\end{array}$} \\
\hline & & & $\begin{array}{l}\text { standard } \\
\text { deviation }\end{array}$ & $\begin{array}{l}\text { absolute } \\
\text { deviation }\end{array}$ & & & & & & & \\
\hline Argentina & 192 & 160 & 0.52 & 0.29 & 23.6 & 0.24 & 31.9 & 0.15 & 0.02 & 0.031 & 0.0148 \\
\hline Brazil & 192 & 160 & 0.19 & 0.13 & 31.9 & 0.27 & 37.0 & 0.17 & 0.03 & 0.033 & 0.069 \\
\hline Chile & 192 & 160 & 0.12 & 0.08 & 25.7 & 0.22 & 37.6 & 0.54 & 0.24 & 0.007 & 0.031 \\
\hline Colombia & 84 & 84 & 0.12 & 0.09 & 20.7 & 0.19 & 37.1 & 0.33 & 0.05 & 0.005 & 0.012 \\
\hline Greece & 192 & 160 & 0.09 & 0.07 & 15.5 & 0.43 & 52.2 & 0.52 & 0.06 & 0.010 & 0.032 \\
\hline India & 192 & 124 & 0.09 & 0.06 & 32.9 & 0.20 & 48.7 & 0.15 & 0.02 & 0.070 & 0.016 \\
\hline Indonesia & 24 & 24 & 0.37 & 0.15 & 64.8 & 0.18 & 50.3 & 0.55 & 0.08 & 0.830 & 0.005 \\
\hline Jordan & 156 & 156 & 0.07 & 0.05 & 15.3 & 0.56 & 34.4 & 1.19 & 0.30 & 0.012 & 0.019 \\
\hline Korea & 192 & 160 & 0.09 & 0.07 & 40.7 & 0.18 & 61.6 & 0.69 & 0.12 & 0.076 & 0.012 \\
\hline Malaysia & 84 & 84 & 0.10 & 0.11 & 53.7 & 0.20 & 59.1 & 1.38 & 0.62 & 0.011 & 0.012 \\
\hline Mexico & 192 & 148 & 0.16 & 0.04 & 21.1 & 0.19 & 43.3 & 0.28 & 0.05 & 0.054 & 0.059 \\
\hline Nigeria & 84 & 84 & 0.06 & 0.07 & 18.6 & 0.17 & 20.2 & 0.50 & 0.03 & 0.001 & 0.105 \\
\hline Pakistan & 84 & 84 & 0.09 & 0.10 & 51.6 & 0.17 & 29.6 & 0.34 & 0.04 & 0.008 & 0.010 \\
\hline Philippines & 84 & 84 & 0.13 & 0.08 & 23.1 & 0.33 & 23.7 & 0.57 & 0.11 & 0.021 & 0.022 \\
\hline Portugal & 71 & 71 & 0.11 & 0.08 & 22.3 & 0.23 & 60.3 & 0.71 & 0.11 & 0.011 & 0.031 \\
\hline Taiwan & 84 & 84 & 0.10 & 0.05 & 52.6 & 0.19 & 76.1 & 0.93 & 0.48 & 0.222 & 0.012 \\
\hline Thailand & 192 & 136 & 0.07 & 0.11 & 14.1 & 0.33 & 54.1 & 0.58 & 0.06 & 0.043 & 0.014 \\
\hline Turkey & 60 & 36 & 0.14 & 0.11 & 16.9 & 0.28 & 41.0 & 0.45 & 0.06 & 0.019 & 0.018 \\
\hline Venezuela & 84 & 84 & 0.14 & 0.11 & 13.8 & 0.23 & 36.1 & 0.51 & 0.09 & 0.019 & 0.081 \\
\hline Zimbabwe & 192 & 124 & 0.14 & 0.10 & 10.0 & 0.28 & 23.1 & 0.56 & 0.05 & 0.004 & 0.026 \\
\hline
\end{tabular}

All monthly returns from International Finance Corporation and calculated in U.S. dollars. The sample ends in December 1992. 
Table 6

Correlation matrix of the cross-sectional variables

\begin{tabular}{|c|c|c|c|c|c|c|c|c|c|c|}
\hline & Vol & Std. dev & MAD & \#Co & Conc & CCR & $E x+I m$ & Mcap & Turn & FXo \\
\hline Volatility & 1.00 & 0.13 & 0.18 & 0.07 & -0.22 & -0.05 & -0.38 & -0.12 & 0.07 & 0.47 \\
\hline Standard deviation & & 1.00 & 0.99 & 0.02 & -0.04 & 0.01 & -0.09 & -0.05 & 0.10 & 0.09 \\
\hline Mean absolute deviation & & & 1.00 & 0.01 & -0.05 & -0.02 & -0.12 & -0.05 & 0.19 & 0.06 \\
\hline Number of companies & & & & 1.00 & -0.58 & 0.21 & 0.02 & 0.40 & 0.23 & -0.04 \\
\hline Concentration factor & & & & & 1.00 & -0.05 & 0.31 & 0.68 & -0.11 & -0.11 \\
\hline Country credit rating & & & & & & 1.00 & 0.24 & 0.29 & 0.24 & -0.42 \\
\hline Exports+Imports/GDP & & & & & & & 1.00 & 0.69 & 0.04 & -0.37 \\
\hline Market capitalization/GDP & & & & & & & & 1.00 & 0.09 & -0.23 \\
\hline Turnover & & & & & & & & & 1.00 & -0.09 \\
\hline Foreign exchange volatility & & & & & & & & & & 1.00 \\
\hline
\end{tabular}

All monthly returns from International Finance Corporation and calculated in U.S. dollars. The sample ends in December 1992. Std. dev is the standard deviation of the individual stock returns in each country's index, MAD is the mean absolute deviation of the individual stock returns, \#Co is the number of companies in the IFC index, Conc is the asset concentration factor, Cred is country credit rating, Ex+Im is exports+imports divided by GDP, mcap is market capitalization divided by GDP, Turn is turnover (value of trading divided by market capitalization), and FX $\sigma$ is the volatility of the previous three years' exchange rate changes.. 
Table 7

Explaining the cross-section of variance

\begin{tabular}{|c|c|c|c|c|c|c|c|c|c|c|c|c|}
\hline $\begin{array}{l}\text { Fixed } \\
\text { effects }\end{array}$ & Std. dev & Std. dev $^{*}$ & MAD & MAD* & \#Co & Conc & CCR & Ex+Im & Mcap & FX $\sigma$ & $R^{2}$ & Turn \\
\hline \multicolumn{13}{|c|}{ A. Univariate estimation of variance models-White standard errors } \\
\hline$\overline{\mathbf{n}}$ & $\begin{array}{c}0.233 \\
(0.089)\end{array}$ & $\left(\begin{array}{c}2.020 \\
(1.176)\end{array}\right.$ & & & $\begin{array}{c}-0.135 \\
(0.048)\end{array}$ & $\begin{array}{c}-0.307 \\
(0.210)\end{array}$ & $\begin{array}{c}0.0094 \\
(0.0013)\end{array}$ & $\begin{array}{c}-0.968 \\
(0.093)\end{array}$ & $\begin{array}{l}1.046 \\
(0.201)\end{array}$ & $\begin{array}{c}9.165 \\
(0.484)\end{array}$ & 0.3357 & $\begin{array}{r}2.620 \\
(0.814)\end{array}$ \\
\hline $\mathbf{n}$ & & & $\begin{array}{c}0.632 \\
(0.273)\end{array}$ & $\begin{array}{c}3.395 \\
(2.067)\end{array}$ & $\begin{array}{c}-0.128 \\
(0.048)\end{array}$ & $\begin{array}{c}-0.285 \\
(0.209)\end{array}$ & $\begin{array}{c}0.0093 \\
(0.0013)\end{array}$ & $\begin{array}{c}-0.840 \\
(0.094)\end{array}$ & $\begin{array}{c}0.980 \\
(0.223)\end{array}$ & $\begin{array}{c}9.091 \\
(0.489)\end{array}$ & 0.3414 & $\begin{array}{r}2.162 \\
(0.769)\end{array}$ \\
\hline $\mathrm{y}$ & $\begin{array}{c}0.146 \\
(0.057)\end{array}$ & $\begin{array}{l}1.960 \\
(1.036)\end{array}$ & & & $\begin{array}{c}-0.060 \\
(0.050)\end{array}$ & $\begin{array}{l}-1.586 \\
(0.229)\end{array}$ & $\begin{array}{c}-0.0052 \\
(0.0018)\end{array}$ & $\begin{array}{c}-0.529 \\
(0.221)\end{array}$ & $\begin{array}{c}0.249 \\
(0.182)\end{array}$ & $\begin{array}{c}3.168 \\
(0.549)\end{array}$ & 0.5993 & $\begin{array}{r}1.274 \\
(0.742)\end{array}$ \\
\hline $\mathrm{y}$ & & & $\begin{array}{c}0.394 \\
(0.144)\end{array}$ & $\begin{array}{c}4.186 \\
(1.828)\end{array}$ & $\begin{array}{c}-0.038 \\
(0.050)\end{array}$ & $\begin{array}{c}-1.552 \\
(0.229)\end{array}$ & $\begin{array}{l}-0.0053 \\
(0.0018)\end{array}$ & $\begin{array}{c}-0.500 \\
(0.221)\end{array}$ & $\begin{array}{c}0.130 \\
(0.195)\end{array}$ & $\begin{array}{c}3.261 \\
(0.549)\end{array}$ & 0.6007 & $\begin{array}{r}0.982 \\
(0.722)\end{array}$ \\
\hline y & & & $\begin{array}{c}0.431 \\
(0.137)\end{array}$ & $\begin{array}{c}4.942 \\
(1.521)\end{array}$ & $\begin{array}{c}-0.015 \\
(0.038)\end{array}$ & $\begin{array}{c}-1.514 \\
(0.216)\end{array}$ & $\begin{array}{c}-0.0051 \\
(0.0017)\end{array}$ & $\begin{array}{c}-0.462 \\
(0.203)\end{array}$ & & $\begin{array}{c}3.317 \\
(0.593)\end{array}$ & 0.6006 & $\begin{array}{r}0.908 \\
(0.712)\end{array}$ \\
\hline $\mathrm{y}$ & & & $\begin{array}{c}0.424 \\
(0.193)\end{array}$ & $\begin{array}{c}2.097 \\
(0.570)\end{array}$ & $\begin{array}{c}-0.032 \\
(0.050)\end{array}$ & $\begin{array}{c}-1.449 \\
(0.220)\end{array}$ & $\begin{array}{c}-0.0043 \\
(0.0018)\end{array}$ & & $\begin{array}{c}-0.029 \\
(0.180)\end{array}$ & $\begin{array}{c}3.525 \\
(0.570)\end{array}$ & 0.5995 & $\begin{array}{r}1.207 \\
(0.731)\end{array}$ \\
\hline
\end{tabular}

\begin{tabular}{|c|c|c|c|c|c|c|c|c|c|c|c|c|c|c|c|}
\hline $\begin{array}{l}\text { Fixed } \\
\text { effects }\end{array}$ & Std. dev & Std. dev* & MAD & MAD $^{*}$ & \#Co & Conc & CCR & Ex+Im & Mcap & $\mathbf{F X} \sigma$ & $\begin{array}{l}\text { Before- } \\
\text { liberal }\end{array}$ & $\begin{array}{c}\text { Pre- } \\
\text { liberal }\end{array}$ & $\begin{array}{l}\text { During- } \\
\text { liberal }\end{array}$ & $\begin{array}{l}\text { Post- } \\
\text { liberal }\end{array}$ & $R^{2}$ \\
\hline
\end{tabular}

Effect of liberalizations

\begin{tabular}{|c|c|c|c|c|c|c|c|c|c|c|c|c|c|c|c|}
\hline $\mathbf{n}$ & $\begin{array}{c}0.313 \\
(0.092)\end{array}$ & $\begin{array}{c}3.631 \\
(1.226)\end{array}$ & & & $\begin{array}{c}0.211 \\
(0.056)\end{array}$ & $\begin{array}{c}-0.484 \\
(0.212)\end{array}$ & $\begin{array}{c}0.0088 \\
(0.0014)\end{array}$ & $\begin{array}{c}-0.955 \\
(0.093)\end{array}$ & $\begin{array}{c}0.787 \\
(0.209)\end{array}$ & $\begin{array}{c}9.114 \\
(0.500)\end{array}$ & $\begin{array}{c}0.108 \\
(0.085)\end{array}$ & $\begin{array}{c}0.348 \\
(0.094)\end{array}$ & $\begin{array}{c}0.333 \\
(0.110)\end{array}$ & $\begin{array}{c}0.272 \\
(0.098)\end{array}$ & 0.3448 \\
\hline $\mathbf{n}$ & & & $\begin{array}{c}0.807 \\
(0.271) \\
\end{array}$ & $\begin{array}{c}7.049 \\
(2.216) \\
\end{array}$ & $\begin{array}{c}-0.197 \\
(0.056)\end{array}$ & $\begin{array}{l}-0.446 \\
(0.211)\end{array}$ & $\begin{array}{c}0.0087 \\
(0.0014)\end{array}$ & $\begin{array}{r}-0.925 \\
(0.094) \\
\end{array}$ & $\begin{array}{c}0.604 \\
(0.237) \\
\end{array}$ & $\begin{array}{c}9.074 \\
(0.503) \\
\end{array}$ & $\begin{array}{c}0.094 \\
(0.085)\end{array}$ & $\begin{array}{c}0.345 \\
(0.093)\end{array}$ & $\begin{array}{c}0.338 \\
(0.110)\end{array}$ & $\begin{array}{c}0.279 \\
(0.098)\end{array}$ & 0.3508 \\
\hline
\end{tabular}

\begin{tabular}{c|c|c}
\hline & Model & $\begin{array}{c}\chi^{2} \\
{[\mathrm{p} \text {-value] }}\end{array}$ \\
\hline $\begin{array}{c}\text { Volatility lower } \\
\text { after liberalization } \\
\text { Volatility lower }\end{array}$ & Std. dev. & $\begin{array}{r}1.45 \\
0.229] \\
1.09 \\
\text { after liberalization }\end{array}$ \\
\hline
\end{tabular}




\begin{tabular}{|c|c|c|c|c|c|c|c|c|c|c|}
\hline $\begin{array}{l}\text { Fixed } \\
\text { effects }\end{array}$ & Std. dev & Std. dev $^{*}$ & MAD & MAD* & \#Co & Conc & CCR & $\mathrm{Ex}+\mathrm{Im}$ & Mcap & $\mathbf{F X} \sigma$ \\
\hline \multicolumn{11}{|c|}{ B. Univariate estimation of variance models-Group-wise heteroskedasticity } \\
\hline $\mathbf{n}$ & $\begin{array}{c}0.297 \\
(0.058)\end{array}$ & $\begin{array}{c}3.209 \\
(0.988)\end{array}$ & & & $\begin{array}{c}0.032 \\
(0.037)\end{array}$ & $\begin{array}{c}-0.438 \\
(0.195)\end{array}$ & $\begin{array}{c}0.0038 \\
(0.0010)\end{array}$ & $\begin{array}{c}-0.526 \\
(0.071)\end{array}$ & $\begin{array}{c}-0.297 \\
(0.143)\end{array}$ & $\begin{array}{r}8.643 \\
(0.407)\end{array}$ \\
\hline $\mathbf{n}$ & & & $\begin{array}{c}0.763 \\
(0.110)\end{array}$ & $\begin{array}{c}5.560 \\
(1.654)\end{array}$ & $\begin{array}{c}0.049 \\
(0.037)\end{array}$ & $\begin{array}{c}-0.386 \\
(0.194)\end{array}$ & $\begin{array}{c}0.0037 \\
(0.0010)\end{array}$ & $\begin{array}{c}-0.491 \\
(0.070)\end{array}$ & $\begin{array}{c}-0.389 \\
(0.156)\end{array}$ & $\begin{array}{r}8.583 \\
(0.411)\end{array}$ \\
\hline $\mathbf{y}$ & $\begin{array}{c}0.0854 \\
(0.040)\end{array}$ & $\begin{array}{c}1.191 \\
(0.757)\end{array}$ & & & $\begin{array}{c}0.119 \\
(0.040)\end{array}$ & $\begin{array}{c}-1.476 \\
(0.203)\end{array}$ & $\begin{array}{c}-0.008 \\
(0.0014)\end{array}$ & $\begin{array}{c}-0.182 \\
(0.146)\end{array}$ & $\begin{array}{l}-0.476 \\
(0.136)\end{array}$ & $\begin{array}{r}2.619 \\
(0.372)\end{array}$ \\
\hline $\mathbf{y}$ & & & $\begin{array}{c}0.251 \\
(0.076)\end{array}$ & $\begin{array}{c}2.889 \\
(1.338)\end{array}$ & $\begin{array}{c}0.133 \\
(0.041)\end{array}$ & $\begin{array}{c}-1.492 \\
(0.203)\end{array}$ & $\begin{array}{c}-0.0008 \\
(0.0014)\end{array}$ & $\begin{array}{c}-0.154 \\
(0.146)\end{array}$ & $\begin{array}{l}-0.561 \\
(0.148)\end{array}$ & $\begin{array}{r}2.789 \\
(0.380)\end{array}$ \\
\hline $\mathbf{y}$ & & & $\begin{array}{c}0.103 \\
(0.066)\end{array}$ & $\begin{array}{c}-0.229 \\
(1.058)\end{array}$ & $\begin{array}{c}0.033 \\
(\mathbf{0 . 0 3 1})\end{array}$ & $\begin{array}{c}-1.652 \\
(0.195)\end{array}$ & $\begin{array}{c}-0.0015 \\
(0.0014)\end{array}$ & $\begin{array}{c}-0.373 \\
(0.133)\end{array}$ & & $\begin{array}{r}2.533 \\
(0.373)\end{array}$ \\
\hline $\mathbf{y}$ & & & $\begin{array}{c}0.264 \\
(0.077)\end{array}$ & $\begin{array}{l}3.150 \\
(2.129)\end{array}$ & $\begin{array}{c}0.129 \\
(0.040)\end{array}$ & $\begin{array}{c}-1.399 \\
(0.197)\end{array}$ & $\begin{array}{c}-0.0005 \\
(0.0014)\end{array}$ & & $\begin{array}{c}-0.597 \\
(0.139)\end{array}$ & $\begin{array}{r}2.855 \\
(0.377)\end{array}$ \\
\hline
\end{tabular}

\begin{tabular}{|c|c|c|c|c|c|c|c|c|c|c|c|c|c|c|}
\hline $\begin{array}{l}\text { Fixed } \\
\text { effects }\end{array}$ & Std. dev & Std. dev" & MAD & MAD $^{*}$ & \#Co & Conc & CCR & $E x+I m$ & Mcap & FX $\sigma$ & $\begin{array}{l}\text { Before- } \\
\text { liberal }\end{array}$ & $\begin{array}{c}\text { Pre- } \\
\text { liberal } \\
\end{array}$ & $\begin{array}{l}\text { During- } \\
\text { liberal } \\
\end{array}$ & $\begin{array}{c}\text { Post- } \\
\text { liberal }\end{array}$ \\
\hline \multicolumn{15}{|c|}{ Effect of liberalizations } \\
\hline $\mathrm{n}$ & $\begin{array}{c}0.341 \\
(0.061)\end{array}$ & $\begin{array}{c}3.994 \\
(1.093)\end{array}$ & & & $\begin{array}{c}0.022 \\
(0.043)\end{array}$ & $\begin{array}{c}-0.475 \\
(0.200)\end{array}$ & $\begin{array}{l}0.0045 \\
(0.0011)\end{array}$ & $\begin{array}{l}-0.510 \\
(0.071)\end{array}$ & $\begin{array}{l}-0.480 \\
(0.162)\end{array}$ & $\begin{array}{c}8.701 \\
(0.411)\end{array}$ & $\begin{array}{l}-0.130 \\
(0.065)\end{array}$ & $\begin{array}{c}0.132 \\
(0.071)\end{array}$ & $\begin{array}{c}-0.042 \\
(0.084)\end{array}$ & $\begin{array}{c}-0.040 \\
(0.076)\end{array}$ \\
\hline $\mathbf{n}$ & & & $\begin{array}{r}0.865 \\
(0.115) \\
\end{array}$ & $\begin{array}{c}7.374 \\
(1.805) \\
\end{array}$ & $\begin{array}{r}0.035 \\
(0.043) \\
\end{array}$ & $\begin{array}{l}-0.425 \\
(0.199) \\
\end{array}$ & $\begin{array}{c}0.0044 \\
(0.0011)\end{array}$ & $\begin{array}{c}-0.473 \\
(0.071)\end{array}$ & $\begin{array}{c}-0.638 \\
(0.180) \\
\end{array}$ & $\begin{array}{r}8.655 \\
(0.414)\end{array}$ & $\begin{array}{c}-0.144 \\
(0.064)\end{array}$ & $\begin{array}{c}0.130 \\
(0.070)\end{array}$ & $\begin{array}{c}-0.039 \\
(0.083)\end{array}$ & $\begin{array}{r}-0.037 \\
(0.076)\end{array}$ \\
\hline
\end{tabular}

\begin{tabular}{c|c|c}
\hline & Model & $\begin{array}{c}\chi^{2} \\
{[\text { p-value }]}\end{array}$ \\
\hline $\begin{array}{r}\text { Volatility lower } \\
\text { after liberalization } \\
\text { Volatility lower } \\
\text { after liberalization }\end{array}$ & Std. dev. & $\begin{array}{r}12.46 \\
{[<0.001]} \\
11.71 \\
{[<0.001]}\end{array}$ \\
\hline
\end{tabular}




\begin{tabular}{|c|c|c|c|c|c|c|c|c|c|c|}
\hline $\begin{array}{l}\text { Fixed } \\
\text { effects }\end{array}$ & Std. dev & Std. dev $^{*}$ & MAD & MAD* & \#Co & Conc & CCR & Ex+Im & Mcap & FX $\sigma$ \\
\hline \multicolumn{11}{|c|}{ C. Univariate estimation of variance models-Serial correlation and group-wise heteroskedasticity } \\
\hline$\overline{\mathbf{n}}$ & $\begin{array}{c}0.001 \\
(0.014)\end{array}$ & $\begin{array}{c}0.011 \\
(0.240)\end{array}$ & & & $\begin{array}{c}-0.008 \\
(0.057)\end{array}$ & $\begin{array}{c}0.074 \\
(0.222)\end{array}$ & $\begin{array}{c}0.0013 \\
(0.0019)\end{array}$ & $\begin{array}{c}-0.670 \\
(0.131)\end{array}$ & $\begin{array}{c}0.160 \\
(0.103)\end{array}$ & $\begin{array}{r}3.895 \\
(0.633)\end{array}$ \\
\hline $\mathbf{n}$ & & & $\begin{array}{c}-0.009 \\
(0.027)\end{array}$ & $\begin{array}{c}-0.107 \\
(0.399)\end{array}$ & $\begin{array}{c}-0.005 \\
(0.057)\end{array}$ & $\begin{array}{l}-0.016 \\
(0.223)\end{array}$ & $\begin{array}{c}0.0015 \\
(0.0019)\end{array}$ & $\begin{array}{c}-0.855 \\
(0.126)\end{array}$ & $\begin{array}{c}0.176 \\
(0.109)\end{array}$ & $\begin{array}{r}4618 \\
(0.572)\end{array}$ \\
\hline$y$ & $\begin{array}{c}0.002 \\
(0.012)\end{array}$ & $\begin{array}{c}0.067 \\
(0.235)\end{array}$ & & & $\begin{array}{c}0.010 \\
(0.053)\end{array}$ & $\begin{array}{c}-0.070 \\
(0.219)\end{array}$ & $\begin{array}{c}-0.0008 \\
(0.0021)\end{array}$ & $\begin{array}{c}0.359 \\
(0.194)\end{array}$ & $\begin{array}{c}0.153 \\
(0.105)\end{array}$ & $\begin{array}{r}1.292 \\
(0.585)\end{array}$ \\
\hline y & & & $\begin{array}{c}-0.010 \\
(0.023)\end{array}$ & $\begin{array}{c}0.062 \\
(0.377)\end{array}$ & $\begin{array}{c}0.011 \\
(0.053)\end{array}$ & $\begin{array}{c}-0.081 \\
(0.216)\end{array}$ & $\begin{array}{c}-0.0004 \\
(0.0020)\end{array}$ & $\begin{array}{c}0.370 \\
(0.190)\end{array}$ & $\begin{array}{c}0.163 \\
(0.107)\end{array}$ & $\begin{array}{r}1.138 \\
(0.526)\end{array}$ \\
\hline $\mathbf{y}$ & & & $\begin{array}{c}-0.002 \\
(0.020)\end{array}$ & $\begin{array}{c}0.263 \\
(0.281)\end{array}$ & $\begin{array}{c}-0.037 \\
(0.047)\end{array}$ & $\begin{array}{c}-0.009 \\
(0.195)\end{array}$ & $\begin{array}{c}-0.0007 \\
(0.0018)\end{array}$ & $\begin{array}{c}0.340 \\
(0.171)\end{array}$ & & $\begin{array}{r}0.883 \\
(0.492)\end{array}$ \\
\hline y & & & $\begin{array}{c}-0.009 \\
(0.024)\end{array}$ & $\begin{array}{c}0.054 \\
(0.393)\end{array}$ & $\begin{array}{c}0.033 \\
(0.051)\end{array}$ & $\begin{array}{c}-0.159 \\
(0.219)\end{array}$ & $\begin{array}{c}-0.0006 \\
(0.0021)\end{array}$ & & $\begin{array}{c}0.210 \\
(0.111)\end{array}$ & $\begin{array}{r}1.178 \\
(0.536)\end{array}$ \\
\hline
\end{tabular}

\begin{tabular}{|c|c|c|c|c|c|c|c|c|c|c|c|c|c|c|}
\hline $\begin{array}{l}\text { Fixed } \\
\text { effects }\end{array}$ & Std. dev & Std. dev* & MAD & $\mathrm{MAD}^{*}$ & \#Co & Conc & CCR & Ex+Im & Mcap & FX $\sigma$ & $\begin{array}{l}\text { Before- } \\
\text { liberal }\end{array}$ & $\begin{array}{c}\text { Pre- } \\
\text { liberal }\end{array}$ & $\begin{array}{c}\text { During- } \\
\text { liberal }\end{array}$ & $\begin{array}{c}\text { Post- } \\
\text { liberal }\end{array}$ \\
\hline \multicolumn{15}{|c|}{ Effect of liberalizations } \\
\hline $\mathbf{n}$ & $\begin{array}{c}0.002 \\
(0.014)\end{array}$ & $\begin{array}{c}0.034 \\
(0.250)\end{array}$ & & & $\begin{array}{c}0.004 \\
(0.059)\end{array}$ & $\begin{array}{c}0.017 \\
(0.226)\end{array}$ & $\begin{array}{c}0.0010 \\
(0.0019)\end{array}$ & $\begin{array}{c}-0.655 \\
(0.125)\end{array}$ & $\begin{array}{c}0.173 \\
(0.108)\end{array}$ & $\begin{array}{c}4.326 \\
(0.622)\end{array}$ & $\begin{array}{c}0.343 \\
(0.277)\end{array}$ & $\begin{array}{c}0.357 \\
(0.278)\end{array}$ & $\begin{array}{c}0.300 \\
(0.278)\end{array}$ & $\begin{array}{r}0.226 \\
(0.280)\end{array}$ \\
\hline $\mathbf{n}$ & & & $\begin{array}{r}-0.005 \\
(0.027) \\
\end{array}$ & $\begin{array}{l}-0.062 \\
(0.426) \\
\end{array}$ & $\begin{array}{c}0.024 \\
(0.059)\end{array}$ & $\begin{array}{c}-0.041 \\
(0.229) \\
\end{array}$ & $\begin{array}{c}0.0013 \\
(0.0019) \\
\end{array}$ & $\begin{array}{c}-0.800 \\
(0.121)\end{array}$ & $\begin{array}{c}0.191 \\
(0.115)\end{array}$ & $\begin{array}{c}5.074 \\
(0.562)\end{array}$ & $\begin{array}{c}0.391 \\
(0.264)\end{array}$ & $\begin{array}{c}0.398 \\
(0.265)\end{array}$ & $\begin{array}{c}0.331 \\
(0.266)\end{array}$ & $\begin{array}{c}0.247 \\
(0.267)\end{array}$ \\
\hline
\end{tabular}

\begin{tabular}{|c|c|c|}
\hline & Model & $\begin{array}{c}\chi^{2} \\
\text { [p-value] }\end{array}$ \\
\hline $\begin{array}{r}\text { Volatility lower } \\
\text { after liberalization }\end{array}$ & Std dev. & $\begin{array}{r}9.29 \\
{[0.002]}\end{array}$ \\
\hline $\begin{array}{l}\text { Volatility lower } \\
\text { after liberalization }\end{array}$ & MAD & $\begin{array}{r}7.24 \\
{[0.007]}\end{array}$ \\
\hline
\end{tabular}




\begin{tabular}{|c|c|c|c|c|c|c|c|c|c|c|c|c|c|c|}
\hline $\begin{array}{l}\text { Fixed } \\
\text { effects }\end{array}$ & Std. dev & Std. dev $^{*}$ & MAD & MAD* $^{*}$ & \#Co & Conc & CCR & Ex+Im & Mcap & FX $\sigma$ & $\begin{array}{l}\text { Before- } \\
\text { liberal }\end{array}$ & $\begin{array}{c}\text { Pre- } \\
\text { liberal }\end{array}$ & $\begin{array}{c}\text { During- } \\
\text { liberal }\end{array}$ & $\begin{array}{l}\text { Post- } \\
\text { liberal }\end{array}$ \\
\hline \multicolumn{15}{|c|}{ D. World factor variance estimation: } \\
\hline $\mathbf{n}$ & $\begin{array}{c}0.012 \\
(0.016)\end{array}$ & $\begin{array}{c}0.238 \\
(0.291)\end{array}$ & & & $\begin{array}{l}-0.042 \\
(0.048)\end{array}$ & $\begin{array}{l}-0.057 \\
(0.169)\end{array}$ & $\begin{array}{c}-0.0011 \\
(0.0018)\end{array}$ & $\begin{array}{l}-0.767 \\
(0.101)\end{array}$ & $\begin{array}{c}0.166 \\
(0.128)\end{array}$ & $\begin{array}{c}4.146 \\
(0.592)\end{array}$ & $\begin{array}{c}0.499 \\
(0.237)\end{array}$ & $\begin{array}{c}0.482 \\
(0.238)\end{array}$ & $\begin{array}{c}0.461 \\
(0.239)\end{array}$ & $\begin{array}{r}0.429 \\
(0.240)\end{array}$ \\
\hline $\mathbf{n}$ & & & $\begin{array}{c}0.002 \\
(0.033) \\
\end{array}$ & $\begin{array}{c}0.317 \\
(0.548) \\
\end{array}$ & $\begin{array}{c}-0.037 \\
(0.047) \\
\end{array}$ & $\begin{array}{c}-0.075 \\
(0.171) \\
\end{array}$ & $\begin{array}{c}-0.0012 \\
(0.0018) \\
\end{array}$ & $\begin{array}{r}-0.845 \\
(0.097) \\
\end{array}$ & $\begin{array}{c}0.169 \\
(0.129) \\
\end{array}$ & $\begin{array}{c}4.941 \\
(0.558) \\
\end{array}$ & $\begin{array}{c}0.449 \\
(0.202) \\
\end{array}$ & $\begin{array}{r}0.433 \\
(0.203) \\
\end{array}$ & $\begin{array}{c}0.412 \\
(0.204) \\
\end{array}$ & $\begin{array}{r}0.381 \\
(0.205) \\
\end{array}$ \\
\hline
\end{tabular}

\begin{tabular}{c|c|c}
\hline & Model & $\begin{array}{c}\chi^{2} \\
{[p \text {-value] }}\end{array}$ \\
\hline $\begin{array}{c}\text { Volatility lower } \\
\text { after liberalization } \\
\text { Volatility lower } \\
\text { after liberalization }\end{array}$ & Std. dev. & $\begin{array}{r}1.46 \\
0.227] \\
1.45 \\
{[0.227]}\end{array}$ \\
\hline
\end{tabular}

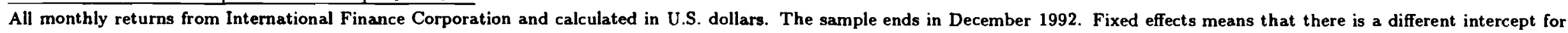

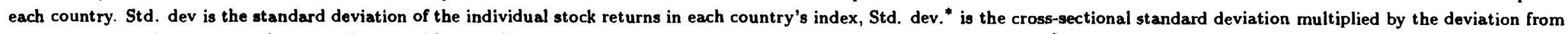

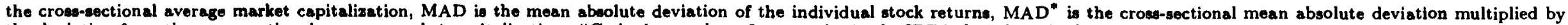

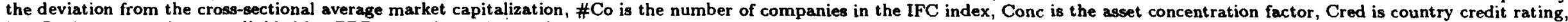

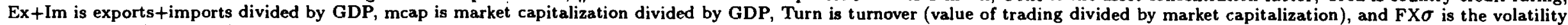
of the previous three years' exchange rate changes.

The Wald test of whether volatility is different is conducted on the indicators for pre-liberalization and post-liberalization. The $\chi^{2}$ statistic has one degree of freedom. 
Table 8

Capital market liberalizations

\begin{tabular}{r|c|c}
\hline Country & Date & Description \\
\hline Argentina & December 1989 & \\
Brazil & May 1991 & \\
Chile & April 1990 & \\
Colombia & February 1991 & \\
Greece & December 1987 & \\
India & June 1992 & \\
Indonesia & September 1990 & \\
Jordan & December 1987 & \\
Korea & January 1992 & \\
Malaysia & December 1988 & \\
Mexico & November 1989 & None \\
Nigeria & February 1991 & \\
Pakistan & November 1991 & \\
Philippines & December 1988 & \\
Portugal & January 1991 & \\
Taiwan & December 1988 & \\
Thailand & August 1989 & \\
Turkey & January 1990 & \\
Venezuela & July 1993 & \\
Zimbabwe & & \\
\hline Bekart & & \\
\hline
\end{tabular}

Data frọ̣n Bekaert (1995). 
Table 9

Economic implications of the cross-sectional variance model

\begin{tabular}{l|l|l|l|l|l|l|l|l|l}
\hline & Volatility & Std. dev & MAD & \#Co & Conc & CCR & Ex+Im & Mcap & FX \\
\hline
\end{tabular}

A. Cross-sectional distribution

\begin{tabular}{c|c|c|c|c|c|c|c|c|c}
\hline 25 th & $\begin{array}{c}0.1194 \\
{[41.40]^{a}}\end{array}$ & 0.06740 & 0.05052 & 15 & 0.3031 & 29.1 & 0.3083 & 0.02081 & 0.04083 \\
Median & $\begin{array}{c}0.0865 \\
{[29.97]^{a}}\end{array}$ & 0.09882 & 0.07318 & 23 & 0.2235 & 44.1 & 0.4896 & 0.04989 & 0.02167 \\
\hline Change & & .03142 & .02266 & $\begin{array}{c}8 \\
{[0.4274]^{b}}\end{array}$ & -0.0796 & 15.0 & 0.1813 & 0.02908 & -0.01916 \\
\hline
\end{tabular}

\begin{tabular}{|c|c|c|c|c|c|c|c|c|c|c|}
\hline Model & Std. dev. & MAD & \#Co & Conc & CCR & Ex+Im & Mcap & FX $\sigma$ & Liberal & Sum \\
\hline \multicolumn{11}{|c|}{ B. Economic impact of cross-sectional factors } \\
\hline OLS-White & 0.117 & & -1.840 & 0.786 & 2.693 & -3.532 & 0.467 & -3.562 & -1.550 & -6.422 \\
\hline OLS-White & & 0.320 & -1.718 & 0.724 & 2.662 & -3.421 & 0.358 & -3.547 & -1.346 & -5.967 \\
\hline GLS-Het & 0.128 & & 0.192 & 0.771 & 1.377 & -1.886 & -0.285 & -3.401 & -3.509 & -6.613 \\
\hline GLS-Het & & 0.344 & 0.305 & 0.690 & 1.346 & -1.749 & -0.378 & -3.383 & -3.407 & -6.232 \\
\hline GLS-Het/SC & 0.001 & & 0.035 & -0.028 & 0.306 & -2.423 & 0.103 & -1.691 & -2.672 & -6.369 \\
\hline GLS-Het/SC & & -0.002 & 0.209 & 0.067 & 0.398 & -2.959 & 0.113 & -1.983 & -3.080 & -7.237 \\
\hline World Factor-Het/GLS & 0.004 & & -0.366 & 0.093 & -0.337 & -2.837 & 0.098 & -1.621 & -1.081 & -6.046 \\
\hline World Factor-Het/GLS & & -0.001 & -0.323 & 0.122 & -0.367 & -3.125 & 0.100 & -1.931 & -1.061 & -6.587 \\
\hline
\end{tabular}

${ }^{a}$ Annualized percentage terms. ${ }^{b}$ Natural logarithm.

The partial effect on annualized volatility from our cross-sectional regression model is

$$
\frac{\partial \ln \sigma^{2}}{\partial x_{i}}=\frac{2}{\sigma} \times \frac{\partial \sigma}{\partial x_{i}}
$$

where $x_{i}$ is the regressor of interest. To measure the effect of a change in the regressor on the fitted volatility, we calculate:

$$
\sqrt{12} \times 100 \times \sigma \times \frac{1}{2} \times \beta_{i} \times \Delta x_{i}
$$

where $\beta_{i}$ is the regression coefficient. The estimation is based on monthly returns from International Finance Corporation and calculated in U.S. dollars. The sample ends in December 1992. Regression coefficients are based on the liberalization models presented in the bottom part of Panels A-D of Table 7. Std. dev is the standard deviation of the individual stock returns in each country's index, MAD is the mean absolute deviation of the individual stock returns, \#Co is the number of companies in the IFC index, Conc is the asset concentration factor, Cred is country credit rating, Ex+Im is exports+imports divided by GDP, mcap is market capitalization divided by GDP, FX $\sigma$ is the volatility of the previous three years' exchange rate changes and Liberal represents the difference between the pre-liberalization and post-liberalization indicator variables. 
The following model is estimated:

$$
\begin{aligned}
r_{i, t} & =\mathbf{X}_{i, t-1}^{\prime} \delta_{i}+\epsilon_{i, t} \\
\epsilon_{i, t} & =\sigma_{i, t} z_{i, t} \\
\sigma_{i, t}^{2} & =w_{i}+\alpha_{i} \sigma_{i, t-1}^{2}+\beta_{i} \epsilon_{i, t-1}^{2}
\end{aligned}
$$

where $r_{i, t}$ represents the return on the national equity index of country $i, \mathbf{X}_{i, t-1}$ represents a set of local information variables that affect the conditional mean, $\sigma_{t}^{2}$ is the conditional variance and $z_{i, t}$ are the standardized residuals formed by dividing the residuals, $\epsilon_{i, t}$ by the volatility, $\sigma_{i t}$. Three different distributional assumptions are used:

\begin{tabular}{|c|c|c|c|c|c|c|c|c|c|c|c|c|}
\hline Country & $\delta_{1}$ & $\delta_{2}$ & $\delta_{3}$ & $\delta_{4}$ & $\delta_{5}$ & $w_{i}$ & $\alpha_{i}$ & $\beta_{i}$ & $p$ & $\mu_{1}$ & $\sigma_{1}$ & $\nu$ \\
\hline$\underset{1}{\text { Argentina }}$ & $\begin{array}{c}0.0555 \\
(0.0346)\end{array}$ & $\begin{array}{c}0.1037 \\
(0.0825)\end{array}$ & $\begin{array}{c}-0.0078 \\
(0.0090)\end{array}$ & $\begin{array}{c}0.0804 \\
(0.2628)\end{array}$ & $\begin{array}{l}-0.6560 \\
(0.4406)\end{array}$ & $\begin{array}{c}0.0268 \\
(0.0129)\end{array}$ & $\begin{array}{c}0.3720 \\
(0.2413)\end{array}$ & $\begin{array}{c}0.3754 \\
(0.4131)\end{array}$ & & & & \\
\hline$\underset{\text { II }}{\text { Argentina }}$ & $\begin{array}{c}-0.0167 \\
(0.0315)\end{array}$ & $\begin{array}{c}0.0335 \\
(0.0607)\end{array}$ & $\begin{array}{c}0.0035 \\
(0.0054)\end{array}$ & $\begin{array}{c}-0.1570 \\
(0.2260)\end{array}$ & $\begin{array}{c}-0.1698 \\
(0.6460)\end{array}$ & $\begin{array}{c}0.0504 \\
(0.0945)\end{array}$ & $\begin{array}{c}0.5107 \\
(0.1988)\end{array}$ & $\begin{array}{c}0.1720 \\
(0.2987)\end{array}$ & & & & $\begin{array}{r}2.4131 \\
(0.9237)\end{array}$ \\
\hline $\begin{array}{l}\text { Argentina } \\
111\end{array}$ & $\begin{array}{c}0.0256 \\
(0.0275)\end{array}$ & $\begin{array}{c}-0.0052 \\
(0.0603)\end{array}$ & $\begin{array}{c}0.0045 \\
(0.0042)\end{array}$ & $\begin{array}{c}-0.1147 \\
(0.1458)\end{array}$ & $\begin{array}{c}-0.0761 \\
(0.4882)\end{array}$ & $\begin{array}{c}0.0483 \\
(0.0200)\end{array}$ & $\begin{array}{c}0.2712 \\
(0.1662)\end{array}$ & $\begin{array}{c}0.1018 \\
(0.0601)\end{array}$ & $\begin{array}{c}0.8883 \\
(0.0452)\end{array}$ & $\begin{array}{c}-0.1734 \\
(0.0480)\end{array}$ & $\begin{array}{c}0.5959 \\
(0.0785)\end{array}$ & \\
\hline $\begin{array}{c}\text { Brazil } \\
1\end{array}$ & $\begin{array}{c}0.0571 \\
(0.0644)\end{array}$ & $\begin{array}{c}0.0987 \\
(0.0843)\end{array}$ & $\begin{array}{c}-0.0017 \\
(0.0042)\end{array}$ & $\begin{array}{c}-0.3129 \\
(0.1807)\end{array}$ & $\begin{array}{c}-1.5094 \\
(0.7886)\end{array}$ & $\begin{array}{c}0.0004 \\
(0.0002)\end{array}$ & $\begin{array}{c}0.8876 \\
(0.0378)\end{array}$ & $\begin{array}{c}0.1124 \\
(0.0378)\end{array}$ & & & & \\
\hline $\begin{array}{c}\text { Brazil } \\
\text { II }\end{array}$ & $\begin{array}{c}0.0504 \\
(0.0676)\end{array}$ & $\begin{array}{c}0.1366 \\
(0.0843)\end{array}$ & $\begin{array}{c}-0.0019 \\
(0.0045)\end{array}$ & $\begin{array}{c}-0.3331 \\
(0.1566)\end{array}$ & $\begin{array}{c}-1.4761 \\
(0.8021)\end{array}$ & $\begin{array}{c}0.0005 \\
(0.0003)\end{array}$ & $\begin{array}{c}0.8733 \\
(0.0391)\end{array}$ & $\begin{array}{c}0.1267 \\
(0.0391)\end{array}$ & & & & $\begin{array}{r}6.9771 \\
(3.8093)\end{array}$ \\
\hline $\begin{array}{c}\text { Brazil } \\
\text { III }\end{array}$ & $\begin{array}{c}0.0517 \\
(0.0247)\end{array}$ & $\begin{array}{c}0.0993 \\
(0.0753)\end{array}$ & $\begin{array}{c}-0.0024 \\
(0.0028)\end{array}$ & $\begin{array}{c}-0.2772 \\
(0.1102)\end{array}$ & $\begin{array}{c}-1.1250 \\
(0.0632)\end{array}$ & $\begin{array}{c}0.0004 \\
(0.0003)\end{array}$ & $\begin{array}{c}0.8841 \\
(0.0000)\end{array}$ & $\begin{array}{c}0.1159 \\
(0.0000)\end{array}$ & $\begin{array}{c}0.5402 \\
(0.0400)\end{array}$ & $\begin{array}{c}-0.3299 \\
(0.0591)\end{array}$ & $\begin{array}{c}0.6350 \\
(0.0526)\end{array}$ & \\
\hline $\begin{array}{c}\text { Chile } \\
1\end{array}$ & $\begin{array}{c}-0.0197 \\
(0.0215)\end{array}$ & $\begin{array}{c}0.1918 \\
(0.0874)\end{array}$ & $\begin{array}{c}0.0062 \\
(0.0026)\end{array}$ & $\begin{array}{c}0.1944 \\
(0.2505)\end{array}$ & $\begin{array}{c}0.0077 \\
(0.0249)\end{array}$ & $\begin{array}{c}0.0001 \\
(0.0001)\end{array}$ & $\begin{array}{c}0.9342 \\
(0.1793)\end{array}$ & $\begin{array}{c}0.0468 \\
(0.1585)\end{array}$ & & & & \\
\hline $\begin{array}{c}\text { Chile } \\
11\end{array}$ & $\begin{array}{c}-0.0220 \\
(0.0236)\end{array}$ & $\begin{array}{c}0.1842 \\
(0.1005)\end{array}$ & $\begin{array}{c}0.0064 \\
(0.0027)\end{array}$ & $\begin{array}{c}0.2629 \\
(0.2071)\end{array}$ & $\begin{array}{c}0.0077 \\
(0.0295)\end{array}$ & $\begin{array}{c}0.0000 \\
(0.0002)\end{array}$ & $\begin{array}{c}0.9886 \\
(0.0334)\end{array}$ & $\begin{array}{c}0.0064 \\
(0.0161)\end{array}$ & & & & $\begin{array}{r}9.1198 \\
(5.2674)\end{array}$ \\
\hline Chile & $b$ & & & & & & & & & & & \\
\hline$\underset{1}{\text { Colombia }}$ & $\begin{array}{c}-0.0301 \\
(\mathbf{0 . 0 2 7 7})\end{array}$ & $\begin{array}{c}0.2857 \\
(0.2138)\end{array}$ & $\begin{array}{c}0.0040 \\
(0.0023)\end{array}$ & $\begin{array}{c}-0.8633 \\
(0.4185)\end{array}$ & $\begin{array}{c}0.0756 \\
(0.2476)\end{array}$ & $\begin{array}{c}0.0033 \\
(0.0053)\end{array}$ & $\begin{array}{c}0.2226 \\
(1.0917)\end{array}$ & $\begin{array}{c}0.2393 \\
(0.2939)\end{array}$ & & & $\because$ & \\
\hline $\begin{array}{c}\text { Colombia } \\
\text { II }\end{array}$ & $\begin{array}{c}-0.0616 \\
(0.0203)\end{array}$ & $\begin{array}{c}0.2169 \\
(0.1140)\end{array}$ & $\begin{array}{c}0.0065 \\
(0.0017)\end{array}$ & $\begin{array}{c}-0.8057 \\
(0.1976)\end{array}$ & $\begin{array}{c}0.1808 \\
(0.2231)\end{array}$ & $\begin{array}{c}0.0021 \\
(0.0017)\end{array}$ & $\begin{array}{c}0.4553 \\
(0.2666)\end{array}$ & $\begin{array}{c}0.5447 \\
(0.2666)\end{array}$ & & & & $\begin{array}{r}2.6339 \\
(0.4001)\end{array}$ \\
\hline $\begin{array}{c}\text { Colonbia } \\
\text { III }\end{array}$ & $\begin{array}{c}-0.0341 \\
(0.0273)\end{array}$ & $\begin{array}{c}0.2395 \\
(0.0933)\end{array}$ & $\begin{array}{c}0.0044 \\
(0.0027)\end{array}$ & $\begin{array}{c}-0.6637 \\
(0.2688)\end{array}$ & $\begin{array}{c}0.1556 \\
(0.1948)\end{array}$ & $\begin{array}{c}0.0012 \\
(0.0008)\end{array}$ & $\begin{array}{c}0.4754 \\
(0.1730)\end{array}$ & $\begin{array}{c}0.3905 \\
(0.1892)\end{array}$ & $\begin{array}{c}0.9616 \\
(0.0331)\end{array}$ & $\begin{array}{c}-0.1231 \\
(0.0541)\end{array}$ & $\begin{array}{c}0.7288 \\
(0.0993)\end{array}$ & \\
\hline
\end{tabular}

$$
\begin{aligned}
& \text { Model I }: z_{i, t} \mid \boldsymbol{I}_{t-1} \sim N(0,1) \\
& \text { Model II }: z_{i, t} \mid \boldsymbol{I}_{t-1} \sim t_{\nu}(0,1) \\
& \text { Model III }: z_{i, t} \mid \boldsymbol{I}_{t-1} \sim \begin{cases}N\left(\mu_{1}, \sigma_{1}\right), & \text { w.p. } p ; \\
N\left(\mu_{2}, \sigma_{2}\right), & \text { w.p. }(1-p) .\end{cases}
\end{aligned}
$$

where $I_{t-1}$ is the information set available to investors at $t-1$. We report robust standard errors as suggested by White (1982). 


\begin{tabular}{|c|c|c|c|c|c|c|c|c|c|c|c|c|}
\hline Country & $\delta_{1}$ & $\delta_{2}$ & $\delta_{3}$ & $\delta_{4}$ & $\delta_{3}$ & $w_{i}$ & $\alpha_{i}$ & $\beta_{i}$ & $p$ & $\mu_{1}$ & $\sigma_{1}$ & $\nu$ \\
\hline $\begin{array}{c}\text { Greece } \\
\text { I }\end{array}$ & $\begin{array}{c}0.0614 \\
(0.0304)\end{array}$ & $\begin{array}{c}0.0003 \\
(0.1985)\end{array}$ & $\begin{array}{c}-0.0055 \\
(0.0022)\end{array}$ & $\begin{array}{c}0.1994 \\
(0.1651)\end{array}$ & $\begin{array}{c}-0.7257 \\
(0.2067)\end{array}$ & $\begin{array}{c}0.0051 \\
(0.0014)\end{array}$ & $\begin{array}{c}0.0000 \\
(0.0000)\end{array}$ & $\begin{array}{c}10000 \\
(0.0000)\end{array}$ & & & & \\
\hline $\begin{array}{c}\text { Greece } \\
\text { II }\end{array}$ & $\begin{array}{c}0.0040 \\
(0.0178)\end{array}$ & $\begin{array}{c}0.0824 \\
(0.0698)\end{array}$ & $\begin{array}{c}-0.0000 \\
(0.0016)\end{array}$ & $\begin{array}{c}0.2292 \\
(0.2078)\end{array}$ & $\begin{array}{c}-0.1219 \\
(0.1700)\end{array}$ & $\begin{array}{c}0.0009 \\
(0.0009)\end{array}$ & $\begin{array}{c}0.7964 \\
(0.1498)\end{array}$ & $\begin{array}{c}0.1766 \\
(0.1775)\end{array}$ & & & & $\begin{array}{r}2.9333 \\
(0.6729)\end{array}$ \\
\hline $\begin{array}{l}\text { Greece } \\
\text { III }\end{array}$ & $\begin{array}{c}0.0148 \\
(0.0195)\end{array}$ & $\begin{array}{c}0.1040 \\
(0.0697)\end{array}$ & $\begin{array}{c}-0.0003 \\
(0.0017)\end{array}$ & $\begin{array}{c}0.1707 \\
(0.2270)\end{array}$ & $\begin{array}{c}-0.1565 \\
(0.1663)\end{array}$ & $\begin{array}{c}0.0007 \\
(0.0010)\end{array}$ & $\begin{array}{c}0.8379 \\
(0.1322)\end{array}$ & $\begin{array}{c}0.0912 \\
(0.0835)\end{array}$ & $\begin{array}{c}0.7406 \\
(0.2027)\end{array}$ & $\begin{array}{l}-0.1297 \\
(0.0766)\end{array}$ & $\begin{array}{c}0.5593 \\
(0.1357)\end{array}$ & \\
\hline$\underset{\text { I }}{\text { India }}$ & $\begin{array}{c}-0.0249 \\
(0.0364)\end{array}$ & $\begin{array}{c}-0.1262 \\
(0.0969)\end{array}$ & $\begin{array}{c}0.0086 \\
(0.0071)\end{array}$ & $\begin{array}{c}-0.3054 \\
(0.1734)\end{array}$ & $\begin{array}{c}0.1773 \\
(0.5118)\end{array}$ & $\begin{array}{c}0.0023 \\
(0.0009)\end{array}$ & $\begin{array}{c}0.2113 \\
(0.1566)\end{array}$ & $\begin{array}{c}0.4321 \\
(0.1961)\end{array}$ & & & & \\
\hline II & $\begin{array}{c}-0.0223 \\
(0.0347)\end{array}$ & $\begin{array}{c}-0.1470 \\
(0.0867)\end{array}$ & $\begin{array}{c}0.0080 \\
(\mathbf{0 . 0 0 6 8})\end{array}$ & $\begin{array}{c}-0.2453 \\
(0.1619)\end{array}$ & $\begin{array}{c}0.1119 \\
(0.4641)\end{array}$ & $\begin{array}{c}0.0017 \\
(0.0009)\end{array}$ & $\begin{array}{c}0.2727 \\
(0.2451)\end{array}$ & $\begin{array}{c}0.5788 \\
(0.2820)\end{array}$ & & & & $\begin{array}{r}4.9292 \\
(1.6940)\end{array}$ \\
\hline $\begin{array}{l}\text { India } \\
\text { III }\end{array}$ & $\begin{array}{c}0.0100 \\
(0.0323)\end{array}$ & $\begin{array}{c}-0.0334 \\
(0.0972)\end{array}$ & $\begin{array}{c}0.0026 \\
(0.0067)\end{array}$ & $\begin{array}{c}-0.2209 \\
(0.1667)\end{array}$ & $\begin{array}{c}-0.1788 \\
(0.3035)\end{array}$ & $\begin{array}{c}0.0002 \\
(0.0002)\end{array}$ & $\begin{array}{c}0.8784 \\
(0.0583)\end{array}$ & $\begin{array}{c}0.0905 \\
(0.0236)\end{array}$ & $\begin{array}{c}0.9576 \\
(0.0167)\end{array}$ & $\begin{array}{c}-0.1277 \\
(0.0406)\end{array}$ & $\begin{array}{c}0.8071 \\
(0.0528)\end{array}$ & \\
\hline$\underset{\text { I }}{\text { Indonesia }}$ & $\begin{array}{c}0.2929 \\
(0.0680)\end{array}$ & $\begin{array}{c}0.5102 \\
(0.1976)\end{array}$ & $\begin{array}{c}0.0452 \\
(0.0309)\end{array}$ & $\begin{array}{c}1.9876 \\
(2.8809)\end{array}$ & $\begin{array}{l}-3.7684 \\
(1.0999)\end{array}$ & $\begin{array}{c}0.0021 \\
(0.0018)\end{array}$ & $\begin{array}{c}0.0000 \\
(0.0000)\end{array}$ & $\begin{array}{c}0.7570 \\
(0.4687)\end{array}$ & & & & \\
\hline $\begin{array}{l}\text { Indonesia } \\
\text { II }\end{array}$ & $\begin{array}{c}0.2929 \\
(0.0680)\end{array}$ & $\begin{array}{c}0.5102 \\
(0.1976)\end{array}$ & $\begin{array}{c}0.0452 \\
(0.0309)\end{array}$ & $\begin{array}{c}1.9876 \\
(2.8809)\end{array}$ & $\begin{array}{c}-3.7684 \\
(1.0999)\end{array}$ & $\begin{array}{c}0.0021 \\
(0.0018)\end{array}$ & $\begin{array}{c}0.0000 \\
(0.0000)\end{array}$ & $\begin{array}{c}0.7570 \\
(0.4687)\end{array}$ & & & & 36102 \\
\hline $\begin{array}{l}\text { Indonesia } \\
\text { III }\end{array}$ & $\begin{array}{c}0.6119 \\
(0.0019)\end{array}$ & $\begin{array}{c}0.5384 \\
(0.0444)\end{array}$ & $\begin{array}{c}0.1090 \\
(0.0069)\end{array}$ & $\begin{array}{c}2.2460 \\
(0.6689)\end{array}$ & $\begin{array}{c}-8.2650 \\
(0.3949)\end{array}$ & $\begin{array}{c}0.0025 \\
(0.0041)\end{array}$ & $\begin{array}{c}0.7297 \\
(0.2906)\end{array}$ & $\begin{array}{c}0.0479 \\
(0.0828)\end{array}$ & $\begin{array}{c}0.3447 \\
(0.0793)\end{array}$ & $\begin{array}{c}0.9428 \\
(0.1383)\end{array}$ & $\begin{array}{c}0.0375 \\
(0.0156)\end{array}$ & \\
\hline$\underset{\text { I }}{\text { Jordan }}$ & $\begin{array}{c}-0.0047 \\
(0.0145)\end{array}$ & $\begin{array}{c}-0.0224 \\
(0.1023)\end{array}$ & $\begin{array}{c}-0.0016 \\
(0.0019)\end{array}$ & $\begin{array}{c}-0.0735 \\
(0.2500)\end{array}$ & $\begin{array}{c}0.0535 \\
(0.0592)\end{array}$ & $\begin{array}{c}0.0002 \\
(0.0002)\end{array}$ & $\begin{array}{c}0.7677 \\
(0.0780)\end{array}$ & $\begin{array}{c}0.1687 \\
(0.0933)\end{array}$ & & & & \\
\hline III & $\begin{array}{c}-0.0161 \\
(0.0166)\end{array}$ & $\begin{array}{c}-0.0899 \\
(0.2505)\end{array}$ & $\begin{array}{c}-0.0012 \\
(0.0043)\end{array}$ & $\begin{array}{c}-0.0238 \\
(1.2503)\end{array}$ & $\begin{array}{c}0.0777 \\
(0.0691)\end{array}$ & $\begin{array}{c}0.0018 \\
(0.0005)\end{array}$ & $\begin{array}{c}0.0024 \\
(0.0964)\end{array}$ & $\begin{array}{c}0.4194 \\
(0.2616)\end{array}$ & & & & $\begin{array}{r}4.6172 \\
(2.0591)\end{array}$ \\
\hline $\begin{array}{c}\text { Jordan } \\
\text { III }\end{array}$ & $\begin{array}{c}0.0010 \\
(0.0152)\end{array}$ & $\begin{array}{c}-0.0416 \\
(0.1122)\end{array}$ & $\begin{array}{c}-0.0012 \\
(0.0019)\end{array}$ & $\begin{array}{c}-0.1079 \\
(0.1088)\end{array}$ & $\begin{array}{c}0.0299 \\
(0.0608)\end{array}$ & $\begin{array}{c}0.0002 \\
(0.0002)\end{array}$ & $\begin{array}{c}0.8178 \\
(0.0830)\end{array}$ & $\begin{array}{c}0.0917 \\
(0.0931)\end{array}$ & $\begin{array}{c}0.4813 \\
(0.0984)\end{array}$ & $\begin{array}{c}-0.3200 \\
(0.1257)\end{array}$ & $\begin{array}{c}0.4791 \\
(0.0958)\end{array}$ & \\
\hline$\underset{1}{\text { Korea }}$ & $\begin{array}{c}0.0160 \\
(0.0455)\end{array}$ & $\begin{array}{c}-0.0624 \\
(0.0802)\end{array}$ & $\begin{array}{c}0.0031 \\
(0.0072)\end{array}$ & $\begin{array}{c}1.9988 \\
(0.8226)\end{array}$ & $\begin{array}{c}-0.0382 \\
(0.1452)\end{array}$ & $\begin{array}{c}0.0007 \\
(0.0004)\end{array}$ & $\begin{array}{c}0.8182 \\
(0.0680)\end{array}$ & $\begin{array}{c}0.1045 \\
(0.0747)\end{array}$ & & & & \\
\hline$\underset{\text { II }}{\text { Korea }}$ & $\begin{array}{c}0.0322 \\
(0.0369)\end{array}$ & $\begin{array}{c}-0.0089 \\
(0.0663)\end{array}$ & $\begin{array}{c}-0.0013 \\
(0.0057)\end{array}$ & $\begin{array}{c}2.0056 \\
(1.4053)\end{array}$ & $\begin{array}{c}-0.1089 \\
(0.1089)\end{array}$ & $\begin{array}{c}0.0005 \\
(0.0004)\end{array}$ & $\begin{array}{c}0.8499 \\
(0.0519)\end{array}$ & $\begin{array}{c}0.0983 \\
(0.0555)\end{array}$ & & & & $\begin{array}{r}5.0621 \\
(2.1242)\end{array}$ \\
\hline $\begin{array}{c}\text { Korea } \\
\text { III }\end{array}$ & $\begin{array}{c}0.0236 \\
(0.0341)\end{array}$ & $\begin{array}{c}-0.0336 \\
(0.0702)\end{array}$ & $\begin{array}{c}0.0019 \\
(0.0052)\end{array}$ & $\begin{array}{c}2.2360 \\
(0.8078)\end{array}$ & $\begin{array}{c}-0.0543 \\
(0.1012)\end{array}$ & $\begin{array}{c}0.0007 \\
(0.0004)\end{array}$ & $\begin{array}{c}0.8213 \\
(0.0617)\end{array}$ & $\begin{array}{c}0.1125 \\
(0.0638)\end{array}$ & $\begin{array}{c}0.6335 \\
(0.1495)\end{array}$ & $\begin{array}{c}-0.3808 \\
(0.1266)\end{array}$ & $\begin{array}{c}0.5781 \\
(0.0983)\end{array}$ & \\
\hline$\underset{1}{\text { Malaysia }}$ & $\begin{array}{c}0.0154 \\
(0.0991)\end{array}$ & $\begin{array}{c}0.0422 \\
(0.2511)\end{array}$ & $\begin{array}{c}0.0208 \\
(0.0370)\end{array}$ & $\begin{array}{c}1.1567 \\
(0.6053)\end{array}$ & $\begin{array}{c}-0.0650 \\
(0.0229)\end{array}$ & $\begin{array}{c}0.0028 \\
(0.0017)\end{array}$ & $\begin{array}{c}0.0000 \\
(0.0000)\end{array}$ & $\begin{array}{c}0.6091 \\
(0.7770)\end{array}$ & & & & \\
\hline$\underset{\text { II }}{\text { Malaysia }}$ & $\begin{array}{c}-0.0285 \\
(0.0435)\end{array}$ & $\begin{array}{c}-0.0456 \\
(0.1146)\end{array}$ & $\begin{array}{c}0.0372 \\
(0.0165)\end{array}$ & $\begin{array}{c}0.9407 \\
(0.1251)\end{array}$ & $\begin{array}{c}-0.0592 \\
(0.0273)\end{array}$ & $\begin{array}{c}0.0038 \\
(0.0007)\end{array}$ & $\begin{array}{c}0.0000 \\
(0.0000)\end{array}$ & $\begin{array}{c}0.2711 \\
(0.1246)\end{array}$ & & & & $\begin{array}{r}7.9236 \\
(0.5560)\end{array}$ \\
\hline $\begin{array}{c}\text { Malaysia } \\
\text { III }\end{array}$ & $\begin{array}{c}-0.1136 \\
(0.0017)\end{array}$ & $\begin{array}{c}0.0405 \\
(0.0006)\end{array}$ & $\begin{array}{c}0.0618 \\
(0.0016)\end{array}$ & $\begin{array}{c}0.2503 \\
(0.0000)\end{array}$ & $\begin{array}{c}-0.0378 \\
(0.0007)\end{array}$ & $\begin{array}{l}954.3000 \\
(0.0011)\end{array}$ & $\begin{array}{c}0.7055 \\
(\mathbf{0 . 0 0 0 0 )}\end{array}$ & $\begin{array}{c}0.2945 \\
(0.0000)\end{array}$ & $\begin{array}{c}1.0000 \\
(0.0000)\end{array}$ & $\begin{array}{c}0.0000 \\
(0.0000)\end{array}$ & $\begin{array}{c}0.0013 \\
(0.0000)\end{array}$ & \\
\hline $\begin{array}{c}\text { Mexico } \\
\text { I }\end{array}$ & $\begin{array}{c}0.0278 \\
(0.0284)\end{array}$ & $\begin{array}{c}0.2443 \\
(0.1085)\end{array}$ & $\begin{array}{c}-0.0028 \\
(0.0050)\end{array}$ & $\begin{array}{c}-0.5167 \\
(0.3651)\end{array}$ & $\begin{array}{c}-0.0392 \\
(0.1631)\end{array}$ & $\begin{array}{c}0.0016 \\
(0.0011)\end{array}$ & $\begin{array}{c}0.6652 \\
(0.1107)\end{array}$ & $\begin{array}{c}0.2371 \\
(0.0716)\end{array}$ & & & & \\
\hline$\underset{\text { II }}{\text { Mexico }}$ & $\begin{array}{c}-0.000 \overline{1} \\
(0.0214)\end{array}$ & $\begin{array}{c}0.2472 \\
(0.0878)\end{array}$ & $\begin{array}{c}0.0017 \\
(0.0040)\end{array}$ & $\begin{array}{c}-0.6241 \\
(0.3179)\end{array}$ & $\begin{array}{c}0.1331 \\
(0.1101)\end{array}$ & $\begin{array}{c}0.0031 \\
(0.0015)\end{array}$ & $\begin{array}{c}0.5046 \\
(0.1634)\end{array}$ & $\begin{array}{c}0.2982 \\
(0.1221)\end{array}$ & & & & $\begin{array}{r}5.5846 \\
(2.2728)\end{array}$ \\
\hline $\begin{array}{c}\text { Mexico } \\
\text { III }\end{array}$ & $\begin{array}{c}0.0275 \\
(0.0236)\end{array}$ & $\begin{array}{c}0.2442 \\
(0.0923) \\
\end{array}$ & $\begin{array}{c}-0.0029 \\
(0.0045) \\
\end{array}$ & $\begin{array}{c}-0.5431 \\
(0.1816) \\
\end{array}$ & $\begin{array}{c}-0.0397 \\
(0.1204) \\
\end{array}$ & $\begin{array}{c}0.0025 \\
(0.0005) \\
\end{array}$ & $\begin{array}{c}0.6725 \\
(0.0000) \\
\end{array}$ & $\begin{array}{c}0.3275 \\
(0.0000) \\
\end{array}$ & $\begin{array}{c}1.0000 \\
(0.0000)\end{array}$ & $\begin{array}{c}0.0026 \\
(0.0001) \\
\end{array}$ & $\begin{array}{c}0.8135 \\
(\mathbf{0 . 0 0 9 2 )} \\
\end{array}$ & \\
\hline
\end{tabular}




\begin{tabular}{|c|c|c|c|c|c|c|c|c|c|c|c|c|}
\hline Country & $\delta_{1}$ & $\delta_{2}$ & $\delta_{3}$ & $\delta_{4}$ & $\delta_{5}$ & $w_{i}$ & $\alpha_{i}$ & $\beta_{i}$ & $p$ & $\mu_{1}$ & $\sigma_{1}$ & $\nu$ \\
\hline$\underset{I}{\text { Nigeria }}$ & $\begin{array}{c}0.0390 \\
(0.0264)\end{array}$ & $\begin{array}{c}0.0650 \\
(0.2594)\end{array}$ & $\begin{array}{c}0.0012 \\
(0.0014)\end{array}$ & $\begin{array}{c}-0.0455 \\
(0.3136)\end{array}$ & $\begin{array}{c}-0.7503 \\
(0.5743)\end{array}$ & $\begin{array}{c}0.0012 \\
(0.0008)\end{array}$ & $\begin{array}{c}0.2386 \\
(0.0667)\end{array}$ & $\begin{array}{c}0.7614 \\
(0.0667)\end{array}$ & & & & \\
\hline $\begin{array}{l}\text { Nigeria } \\
\text { II }\end{array}$ & $\begin{array}{c}-0.0147 \\
(0.0479)\end{array}$ & $\begin{array}{c}0.2478 \\
(0.2558)\end{array}$ & $\begin{array}{c}0.0027 \\
(0.0023)\end{array}$ & $\begin{array}{c}-0.2953 \\
(0.2586)\end{array}$ & $\begin{array}{c}0.0439 \\
(1.1906)\end{array}$ & $\begin{array}{c}0.0059 \\
(0.0057)\end{array}$ & $\begin{array}{c}0.6446 \\
(0.2893)\end{array}$ & $\begin{array}{c}0.3553 \\
(0.2893)\end{array}$ & & & & $\begin{array}{r}2.1437 \\
(0.1245)\end{array}$ \\
\hline $\begin{array}{l}\text { Nigeria } \\
\text { IIII }\end{array}$ & $\begin{array}{c}-0.0002 \\
(0.0172)\end{array}$ & $\begin{array}{c}0.3983 \\
(0.0959)\end{array}$ & $\begin{array}{c}0.0011 \\
(0.0017)\end{array}$ & $\begin{array}{r}-0.3966 \\
(0.0981)\end{array}$ & $\begin{array}{c}0.1061 \\
(0.1706)\end{array}$ & $\begin{array}{c}0.0062 \\
(0.0022)\end{array}$ & $\begin{array}{c}0.0000 \\
(0.0000)\end{array}$ & $\begin{array}{c}1.0000 \\
(0.0000)\end{array}$ & $\begin{array}{c}0.8214 \\
(0.0205)\end{array}$ & $\begin{array}{c}-0.0656 \\
(0.0594)\end{array}$ & $\begin{array}{c}0.4263 \\
(0.0672)\end{array}$ & \\
\hline $\begin{array}{c}\text { Pakistan } \\
I\end{array}$ & $\begin{array}{c}0.0505 \\
(0.0245)\end{array}$ & $\begin{array}{c}0.1623 \\
(0.1397)\end{array}$ & $\begin{array}{c}-0.0034 \\
(0.0032)\end{array}$ & $\begin{array}{c}-0.0629 \\
(0.3518)\end{array}$ & $\begin{array}{c}-0.6884 \\
(0.2232)\end{array}$ & $\begin{array}{c}0.0002 \\
(0.0001)\end{array}$ & $\begin{array}{c}0.6245 \\
(0.0000)\end{array}$ & $\begin{array}{c}0.3756 \\
(0.0000)\end{array}$ & & & & \\
\hline $\begin{array}{l}\text { Pakistan } \\
\text { II }\end{array}$ & $\begin{array}{c}0.0705 \\
(0.0353)\end{array}$ & $\begin{array}{c}0.0761 \\
(0.1095)\end{array}$ & $\begin{array}{c}-0.0063 \\
(0.0038)\end{array}$ & $\begin{array}{c}0.3354 \\
(0.5124)\end{array}$ & $\begin{array}{c}-0.4853 \\
(0.4027)\end{array}$ & $\begin{array}{c}0.0002 \\
(0.0001)\end{array}$ & $\begin{array}{c}0.7395 \\
(0.0871)\end{array}$ & $\begin{array}{c}0.2408 \\
(0.2211)\end{array}$ & & & & $\begin{array}{r}3.6192 \\
(1.5709)\end{array}$ \\
\hline $\begin{array}{c}\text { Pakistan } \\
\text { III }\end{array}$ & $\begin{array}{c}0.0728 \\
(0.0233)\end{array}$ & $\begin{array}{c}0.0939 \\
(0.0903)\end{array}$ & $\begin{array}{c}-0.0065 \\
(0.0029)\end{array}$ & $\begin{array}{c}0.1722 \\
(0.1633)\end{array}$ & $\begin{array}{c}-0.3275 \\
(0.1829)\end{array}$ & $\begin{array}{c}0.0001 \\
(0.0000)\end{array}$ & $\begin{array}{c}0.7857 \\
(0.0000)\end{array}$ & $\begin{array}{c}0.2143 \\
(0.0000)\end{array}$ & $\begin{array}{c}0.9777 \\
(0.0007)\end{array}$ & $\begin{array}{c}-0.1018 \\
(0.0016)\end{array}$ & $\begin{array}{c}0.7442 \\
(0.0141)\end{array}$ & \\
\hline Philippines & $\begin{array}{c}0.0642 \\
(0.0535)\end{array}$ & $\begin{array}{c}0.2517 \\
(0.1072)\end{array}$ & $\begin{array}{c}0.0060 \\
(0.0089)\end{array}$ & $\begin{array}{c}-0.0201 \\
(1.1309)\end{array}$ & $\begin{array}{c}-0.4998 \\
(0.2985)\end{array}$ & $\begin{array}{c}0.0000 \\
(0.0000)\end{array}$ & $\begin{array}{c}0.9959 \\
(0.0040)\end{array}$ & $\begin{array}{c}0.0000 \\
(0.0000)\end{array}$ & & & & \\
\hline $\begin{array}{l}\text { Philippines } \\
\text { II }\end{array}$ & $\begin{array}{c}0.0477 \\
(0.0444)\end{array}$ & $\begin{array}{c}0.2262 \\
(0.0810)\end{array}$ & $\begin{array}{c}0.0044 \\
(0.0103)\end{array}$ & $\begin{array}{c}-0.2585 \\
(0.2784)\end{array}$ & $\begin{array}{c}-0.3532 \\
(0.2299)\end{array}$ & $\begin{array}{c}0.0000 \\
(0.0000)\end{array}$ & $\begin{array}{c}0.9964 \\
(0.0051)\end{array}$ & $\begin{array}{c}0.0000 \\
(0.0000)\end{array}$ & & & & $\begin{array}{r}4.2052 \\
(2.0320)\end{array}$ \\
\hline Philippines & $\begin{array}{c}0.1035 \\
(0.0544)\end{array}$ & $\begin{array}{c}0.3211 \\
(0.0844)\end{array}$ & $\begin{array}{c}-0.0054 \\
(0.0077)\end{array}$ & $\begin{array}{c}-0.2579 \\
(0.2315)\end{array}$ & $\begin{array}{c}-0.5204 \\
(0.2629)\end{array}$ & $\begin{array}{c}0.0071 \\
(0.0025)\end{array}$ & $\begin{array}{c}0.1399 \\
(0.2021)\end{array}$ & $\begin{array}{c}0.4064 \\
(0.4320)\end{array}$ & $\begin{array}{c}0.9212 \\
(0.0279)\end{array}$ & $\begin{array}{c}-0.2163 \\
(0.0600)\end{array}$ & $\begin{array}{c}0.6866 \\
(0.0782)\end{array}$ & \\
\hline $\begin{array}{l}\text { Portugal } \\
\text { I }\end{array}$ & $\begin{array}{c}0.0815 \\
(0.0313)\end{array}$ & $\begin{array}{c}0.2563 \\
(0.0498)\end{array}$ & $\begin{array}{c}-0.0005 \\
(0.0080)\end{array}$ & $\begin{array}{c}-0.5390 \\
(0.2256)\end{array}$ & $\begin{array}{c}-0.7575 \\
(0.2299)\end{array}$ & $\begin{array}{c}0.0021 \\
(0.0007)\end{array}$ & $\begin{array}{c}0.0002 \\
(0.0000)\end{array}$ & $\begin{array}{c}0.9998 \\
(0.0000)\end{array}$ & & & & \\
\hline $\begin{array}{c}\text { Portugal } \\
\text { II }\end{array}$ & $\begin{array}{c}0.0815 \\
(0.0143)\end{array}$ & $\begin{array}{c}0.2563 \\
(0.0447)\end{array}$ & $\begin{array}{c}-0.0005 \\
(0.0032)\end{array}$ & $\begin{array}{c}-0.5390 \\
(0.1185)\end{array}$ & $\begin{array}{c}-0.7577 \\
(0.1410)\end{array}$ & $\begin{array}{c}0.0021 \\
(0.0008)\end{array}$ & $\begin{array}{c}0.0000 \\
(0.0000)\end{array}$ & $\begin{array}{c}1.0000 \\
(0.0000)\end{array}$ & & & & $\begin{array}{r}278630.0 \\
(0.1999)\end{array}$ \\
\hline $\begin{array}{l}\text { Portugal } \\
\text { III }\end{array}$ & & & & & & & & & & & & \\
\hline$\underset{1}{\text { Taiwan }}$ & $\begin{array}{c}0.0564 \\
(0.0559)\end{array}$ & $\begin{array}{c}0.1702 \\
(0.1501)\end{array}$ & $\begin{array}{c}-0.0100 \\
(0.0235)\end{array}$ & $\begin{array}{c}1.3332 \\
(2.8907)\end{array}$ & $\begin{array}{c}-0.0856 \\
(0.0844)\end{array}$ & $\begin{array}{c}0.0028 \\
(0.0047)\end{array}$ & $\begin{array}{c}0.5574 \\
(0.1628)\end{array}$ & $\begin{array}{c}0.3827 \\
(0.3512)\end{array}$ & & & & \\
\hline $\begin{array}{c}\text { Taiwan } \\
\text { II }\end{array}$ & $\begin{array}{c}0.0368 \\
(0.0465)\end{array}$ & $\begin{array}{c}0.1043 \\
(0.1550)\end{array}$ & $\begin{array}{c}-0.0015 \\
(0.0159)\end{array}$ & $\begin{array}{c}0.7543 \\
(1.5846)\end{array}$ & $\begin{array}{c}-0.0670 \\
(0.0568)\end{array}$ & $\begin{array}{c}0.0017 \\
(0.0018)\end{array}$ & $\begin{array}{c}0.6487 \\
(0.1389)\end{array}$ & $\begin{array}{c}0.3512 \\
(0.1391)\end{array}$ & & & & $\begin{array}{r}5.28490 \\
(2.9287)\end{array}$ \\
\hline $\begin{array}{l}\text { Taiwan } \\
\text { III }\end{array}$ & $\begin{array}{c}0.0363 \\
()^{6}\end{array}$ & $\begin{array}{c}0.0155 \\
()\end{array}$ & $\begin{array}{c}0.0028 \\
()\end{array}$ & $\begin{array}{c}1.1900 \\
()\end{array}$ & $\begin{array}{c}-0.0467 \\
()\end{array}$ & $\begin{array}{c}0.0016 \\
()\end{array}$ & $\begin{array}{c}0.6288 \\
()\end{array}$ & $\begin{array}{c}0.3712 \\
()\end{array}$ & $\begin{array}{c}0.8298 \\
()\end{array}$ & $\begin{array}{c}-0.2518 \\
()\end{array}$ & $\begin{array}{c}0.7333 \\
()\end{array}$ & \\
\hline $\begin{array}{l}\text { Thailand } \\
\text { I }\end{array}$ & $\begin{array}{c}0.0337 \\
(0.0240)\end{array}$ & $\begin{array}{c}0.1987 \\
(0.0951)\end{array}$ & $\begin{array}{c}-0.0024 \\
(0.0021)\end{array}$ & $\begin{array}{c}-0.1539 \\
(0.2188)\end{array}$ & $\begin{array}{c}-0.0509 \\
(0.1089)\end{array}$ & $\begin{array}{c}0.0015 \\
(0.0007)\end{array}$ & $\begin{array}{c}0.4167 \\
(0.1228)\end{array}$ & $\begin{array}{c}0.3292 \\
(0.1433)\end{array}$ & & & & \\
\hline $\begin{array}{l}\text { Thailand } \\
\text { II }\end{array}$ & $\begin{array}{c}0.0279 \\
(\mathbf{0 . 0 2 8 5})\end{array}$ & $\begin{array}{c}0.2069 \\
(0.0969)\end{array}$ & $\begin{array}{c}-0.0019 \\
(0.0024)\end{array}$ & $\begin{array}{c}-0.0697 \\
(0.2689)\end{array}$ & $\begin{array}{c}-0.0350 \\
(0.1597)\end{array}$ & $\begin{array}{c}0.0010 \\
(0.0009)\end{array}$ & $\begin{array}{c}0.5895 \\
(0.1830)\end{array}$ & $\begin{array}{c}0.2749 \\
(0.1460)\end{array}$ & & & & $\begin{array}{r}5.0682 \\
(1.9868)\end{array}$ \\
\hline $\begin{array}{l}\text { Thailand } \\
\text { III }\end{array}$ & $\begin{array}{c}0.0293 \\
(0.0267)\end{array}$ & $\begin{array}{c}0.1646 \\
(0.1551)\end{array}$ & $\begin{array}{c}-0.0009 \\
(0.0020)\end{array}$ & $\begin{array}{c}-0.1716 \\
(0.2170)\end{array}$ & $\begin{array}{c}-0.1123 \\
(0.1561)\end{array}$ & $\begin{array}{c}0.0018 \\
(0.0013)\end{array}$ & $\begin{array}{c}0.3812 \\
(0.2256)\end{array}$ & $\begin{array}{c}0.3194 \\
(0.1582)\end{array}$ & $\begin{array}{c}0.3525 \\
(0.2176)\end{array}$ & $\begin{array}{c}-0.3231 \\
(0.1242)\end{array}$ & $\begin{array}{c}0.3812 \\
(0.3066)\end{array}$ & \\
\hline $\begin{array}{c}\text { Turkey } \\
1\end{array}$ & $\begin{array}{c}-0.0015 \\
(0.0773)\end{array}$ & $\begin{array}{c}-0.0230 \\
(0.1225)\end{array}$ & $\begin{array}{c}0.0139 \\
(0.0095)\end{array}$ & $\begin{array}{c}1.7111 \\
(0.1829)\end{array}$ & $\begin{array}{c}-0.3210 \\
(0.3013)\end{array}$ & $\begin{array}{c}0.0000 \\
(\mathbf{0 . 0 0 0 0})\end{array}$ & $\begin{array}{c}0.9954 \\
(0.0000)\end{array}$ & $\begin{array}{c}0.0000 \\
(0.0000)\end{array}$ & & & & \\
\hline $\begin{array}{l}\text { Turkey } \\
\text { II }\end{array}$ & $\begin{array}{c}-0.1195 \\
(0.1447)\end{array}$ & $\begin{array}{c}-0.0860 \\
(0.1264)\end{array}$ & $\begin{array}{c}0.0155 \\
(0.0124)\end{array}$ & $\begin{array}{c}1.5392 \\
(0.4342)\end{array}$ & $\begin{array}{c}0.3125 \\
(0.6298)\end{array}$ & $\begin{array}{c}0.0040 \\
(0.0063)\end{array}$ & $\begin{array}{c}0.7247 \\
(0.0901)\end{array}$ & $\begin{array}{c}0.2706 \\
(0.2124)\end{array}$ & & & & $\begin{array}{r}2.8914 \\
(0.9168)\end{array}$ \\
\hline $\begin{array}{l}\text { Turkey } \\
\text { III }\end{array}$ & $\begin{array}{c}0.0512 \\
(\mathbf{0 . 0 0 3 3}) \\
\end{array}$ & $\begin{array}{c}-0.0845 \\
(0.0008)\end{array}$ & $\begin{array}{c}0.003 \bar{i} \\
(0.0001)\end{array}$ & $\begin{array}{c}1.0200 \\
(0.0090)\end{array}$ & $\begin{array}{c}-0.1986 \\
(0.0089) \\
\end{array}$ & $\begin{array}{c}0.0001 \\
(0.0000) \\
\end{array}$ & $\begin{array}{c}0.8932 \\
(0.0016) \\
\end{array}$ & $\begin{array}{c}0.0831 \\
(0.0015)\end{array}$ & $\begin{array}{c}0.1844 \\
(0.3310) \\
\end{array}$ & $\begin{array}{c}-0.8060 \\
(0.0172)\end{array}$ & $\begin{array}{c}0.0016 \\
(0.0023)\end{array}$ & \\
\hline
\end{tabular}


Appendix Table A 1 (continued)

\begin{tabular}{|c|c|c|c|c|c|c|c|c|c|c|c|c|}
\hline Country & $\delta_{1}$ & $\delta_{2}$ & $\delta_{3}$ & $\delta_{4}$ & $\delta_{5}$ & $w_{i}$ & $\alpha_{i}$ & $\beta_{i}$ & $p$ & $\mu_{1}$ & $\sigma_{1}$ & $\nu$ \\
\hline $\begin{array}{c}\text { Vrnezuela } \\
\text { I }\end{array}$ & $\begin{array}{c}-0.0654 \\
(0.0269)\end{array}$ & $\begin{array}{c}0.3008 \\
(0.0699)\end{array}$ & $\begin{array}{c}0.0406 \\
(0.0112)\end{array}$ & $\begin{array}{c}0.2213 \\
(0.1200)\end{array}$ & $\begin{array}{c}0.1857 \\
(0.1889)\end{array}$ & $\begin{array}{c}0.0054 \\
(0.0015)\end{array}$ & $\begin{array}{c}0.0000 \\
(\mathbf{0 . 0 0 0 0})\end{array}$ & $\begin{array}{c}0.9999 \\
(0.0125)\end{array}$ & & & & \\
\hline $\begin{array}{l}\text { Venezuela } \\
\text { II }\end{array}$ & $\begin{array}{c}-0.0657 \\
(0.0287)\end{array}$ & $\begin{array}{c}0.2940 \\
(0.0729)\end{array}$ & $\begin{array}{c}0.0402 \\
(0.0117)\end{array}$ & $\begin{array}{c}0.2279 \\
(0.1302)\end{array}$ & $\begin{array}{c}0.1980 \\
(0.2078)\end{array}$ & $\begin{array}{c}0.0055 \\
(0.0014)\end{array}$ & $\begin{array}{c}0.0000 \\
(\mathbf{0 . 0 0 0 0})\end{array}$ & $\begin{array}{c}1.0000 \\
(0.0000)\end{array}$ & & & & $\begin{array}{r}19.8730 \\
(49.5230)\end{array}$ \\
\hline $\begin{array}{c}\text { Venezuela } \\
\text { III }\end{array}$ & $\frac{-0.0657}{()^{a}}$ & $\underset{()}{0.2911}$ & $\underset{()}{0.0475}$ & $\underset{()}{0.0660}$ & $\underset{()}{-0.1053}$ & $\underset{()}{0.0073}$ & $\underset{()}{0.0000}$ & $\begin{array}{c}0.7785 \\
()\end{array}$ & $\underset{()}{0.2303}$ & $\begin{array}{c}-0.1773 \\
()\end{array}$ & $\underset{()}{0.0912}$ & \\
\hline$\underset{I}{\text { Zimbabwe }}$ & $\begin{array}{c}0.0046 \\
(0.0296)\end{array}$ & $\begin{array}{c}0.1854 \\
(0.0778)\end{array}$ & $\begin{array}{c}0.0022 \\
(0.0026)\end{array}$ & $\begin{array}{c}-0.2494 \\
(0.2541)\end{array}$ & $\begin{array}{c}-0.1341 \\
(0.0773)\end{array}$ & $\begin{array}{c}0.0002 \\
(\mathbf{0 . 0 0 0 2})\end{array}$ & $\begin{array}{c}0.9103 \\
(0.0256)\end{array}$ & $\begin{array}{c}0.0678 \\
(0.0273)\end{array}$ & & & & \\
\hline$\underset{\text { II }}{\text { Zimbabwe }}$ & $\begin{array}{c}0.0048 \\
(0.0252)\end{array}$ & $\begin{array}{c}0.1728 \\
(0.0773)\end{array}$ & $\begin{array}{c}0.0018 \\
(0.0021)\end{array}$ & $\begin{array}{c}-0.2774 \\
(0.2644)\end{array}$ & $\begin{array}{c}-0.1194 \\
(0.0832)\end{array}$ & $\begin{array}{c}0.0003 \\
(\mathbf{0 . 0 0 0 2})\end{array}$ & $\begin{array}{c}0.8982 \\
(0.0276)\end{array}$ & $\begin{array}{c}0.0674 \\
(0.0305)\end{array}$ & & & & $\begin{array}{r}8.2090 \\
(4.1590)\end{array}$ \\
\hline $\begin{array}{c}\text { Zimbabwe } \\
\text { III }\end{array}$ & $\begin{array}{c}0.0080 \\
(0.0327)\end{array}$ & $\begin{array}{c}0.1700 \\
(0.0813)\end{array}$ & $\begin{array}{c}0.0018 \\
(0.0024)\end{array}$ & $\begin{array}{c}-0.2854 \\
(0.2803)\end{array}$ & $\begin{array}{c}-0.1303 \\
(0.1039)\end{array}$ & $\begin{array}{c}0.0003 \\
(0.0002)\end{array}$ & $\begin{array}{c}0.8921 \\
(0.0414)\end{array}$ & $\begin{array}{c}0.0742 \\
(0.0449)\end{array}$ & $\begin{array}{c}0.8086 \\
(\mathbf{0 . 3 0 5 9})\end{array}$ & $\begin{array}{c}-0.0229 \\
(0.1056)\end{array}$ & $\begin{array}{c}0.8191 \\
(0.1686)\end{array}$ & \\
\hline
\end{tabular}

${ }^{a}$ Hessian calculation failed. Standard errors not reported.

${ }^{b}$ Did not converge. 
Appendix Table A2

Diagnostics for the variance models

Model I is the standard normal model. In model II, a t-distribution is assumed. Model III is the semi-parametric ARCH.

\begin{tabular}{|c|c|c|c|c|c|c|c|c|c|c|c|c|}
\hline \multirow[b]{2}{*}{ Country } & \multicolumn{3}{|c|}{$\begin{array}{c}\text { Cumby-Huizinga } \\
\text { serial correlation } \\
\qquad(6)\end{array}$} & \multicolumn{3}{|c|}{$\begin{array}{c}\text { Box-Pierce } \\
\text { squared residuals } \\
Q_{2}(6)\end{array}$} & \multicolumn{3}{|c|}{ skewness } & \multicolumn{3}{|c|}{ kurtosis } \\
\hline & 1 & II & III & I & 11 & III & $\mathbf{I}$ & II & III & 1 & II & III \\
\hline Argentina & $\begin{array}{c}301.360 \\
{[<0.000]}\end{array}$ & $\begin{array}{c}8.225 \\
{[0.222]}\end{array}$ & $\begin{array}{c}3.091 \\
{[0.797]}\end{array}$ & $\begin{array}{l}12.983 \\
{[0.043]}\end{array}$ & $\begin{array}{c}7.893 \\
{[0.246]}\end{array}$ & $\begin{array}{c}7.021 \\
{[0.319]}\end{array}$ & $\begin{array}{c}2.238 \\
(0.631)\end{array}$ & $\begin{array}{c}1.959 \\
(0.531)\end{array}$ & $\begin{array}{c}2.047 \\
(0.522)\end{array}$ & $\begin{array}{l}10.187 \\
(3.817)\end{array}$ & $\begin{array}{c}8.420 \\
(2.647)\end{array}$ & $\begin{array}{r}8.698 \\
(2.780)\end{array}$ \\
\hline Brazil & $\begin{array}{l}16.007 \\
{[0.014]}\end{array}$ & {$\left[\begin{array}{l}54.443 \\
{[<0.000}\end{array}\right]$} & $\begin{array}{l}34.783 \\
{[<0.000]}\end{array}$ & $\begin{array}{c}7.359 \\
{[0.289]}\end{array}$ & $\begin{array}{c}8.044 \\
{[0.235]}\end{array}$ & $\begin{array}{c}7.411 \\
{[0.285]}\end{array}$ & $\begin{array}{c}0.321 \\
(0.332)\end{array}$ & $\begin{array}{c}0.296 \\
(0.334)\end{array}$ & $\begin{array}{c}0.333 \\
(0.325)\end{array}$ & $\begin{array}{c}1.426 \\
(0.714)\end{array}$ & $\begin{array}{c}1.466 \\
(0.733)\end{array}$ & $\begin{array}{r}1.400 \\
(0.695)\end{array}$ \\
\hline Chile & {$[<0.000]$} & {$[<<0.000]$} & $c$ & $\begin{array}{c}3.304 \\
{[0.770]}\end{array}$ & $\begin{array}{c}3.090 \\
{[0.798]}\end{array}$ & c & $\begin{array}{c}0.983 \\
(0.650)\end{array}$ & $\begin{array}{c}0.994 \\
(0.652)\end{array}$ & $c$ & $\begin{array}{c}4.818 \\
(2.954)\end{array}$ & $\begin{array}{c}4.850 \\
(2.973)\end{array}$ & $c$ \\
\hline Colombia & $\begin{array}{l}568.380 \\
{[<0.000]}\end{array}$ & $\begin{array}{l}1379.30 \\
{[<0.000]}\end{array}$ & $\begin{array}{l}1176.80 \\
{[<0.000]}\end{array}$ & {$\left[\begin{array}{c}50.709 \\
{[<0.000]}\end{array}\right.$} & $\begin{array}{c}60.203 \\
{[<0.000]}\end{array}$ & $\begin{array}{c}56.652 \\
{[<0.000]}\end{array}$ & $\begin{array}{c}0.897 \\
(0.630)\end{array}$ & $\begin{array}{c}1.141 \\
(0.532)\end{array}$ & $\begin{array}{c}1.020 \\
(0.581)\end{array}$ & $\begin{array}{c}3.398 \\
(1.564)\end{array}$ & $\begin{array}{c}3.434 \\
(1.784)\end{array}$ & $\begin{array}{r}3.435 \\
(1.693)\end{array}$ \\
\hline Greece & $\begin{array}{l}1347.50 \\
{[<0.000]}\end{array}$ & $\begin{array}{l}180.260 \\
{[<0.000]}\end{array}$ & {$[<0.008]$} & $\begin{array}{l}20.848 \\
{[0.002]}\end{array}$ & $\begin{array}{l}18.262 \\
{[0.006]}\end{array}$ & $\begin{array}{l}17.935 \\
{[0.006]}\end{array}$ & $\begin{array}{c}1.903 \\
(0.463)\end{array}$ & $\begin{array}{c}1.785 \\
(0.463)\end{array}$ & $\begin{array}{c}1.785 \\
(0.466)\end{array}$ & $\begin{array}{c}7.611 \\
(2.139)\end{array}$ & $\begin{array}{c}7.180 \\
(2.084)\end{array}$ & $\begin{array}{r}7.184 \\
(2.095)\end{array}$ \\
\hline India & $\begin{array}{l}1055.400 \\
{[<0.000]}\end{array}$ & {$\left[\begin{array}{c}1951.90 \\
{[<0.000]}\end{array}\right.$} & $\begin{array}{l}1149.200 \\
{[<0.000]}\end{array}$ & {$[<0.000]$} & {$\left[\begin{array}{c}49.405 \\
{[<0.000]}\end{array}\right.$} & {$[<0.000]$} & $\begin{array}{c}0.862 \\
(0.331)\end{array}$ & $\begin{array}{c}0.945 \\
(0.339)\end{array}$ & $\begin{array}{c}0.972 \\
(0.343)\end{array}$ & $\begin{array}{c}3.061 \\
(1.169)\end{array}$ & $\begin{array}{c}3.288 \\
(1.263)\end{array}$ & $\begin{array}{r}2.896 \\
(1.183)\end{array}$ \\
\hline Indonesia & {$[<0.001]$} & {$\left[\begin{array}{l}34.419 \\
{[<0.000]}\end{array}\right.$} & {$[<0.000]$} & $\begin{array}{c}7.377 \\
{[0.287]}\end{array}$ & $\begin{array}{c}7.377 \\
{[0.287]}\end{array}$ & $\begin{array}{c}3.335 \\
{[0.766]}\end{array}$ & $\begin{array}{l}-0.352 \\
(0.315)\end{array}$ & $\begin{array}{c}-0.352 \\
(0.316)\end{array}$ & $\begin{array}{c}-0.548 \\
(0.342)\end{array}$ & $\begin{array}{c}-0.549 \\
(0.500)\end{array}$ & $\begin{array}{c}-0.549 \\
(0.500)\end{array}$ & $\begin{array}{r}-0.640 \\
(0.527)\end{array}$ \\
\hline Jordan & $\begin{array}{l}10.060 \\
{[0.122]}\end{array}$ & $\begin{array}{l}17.526 \\
{[0.008]}\end{array}$ & $\begin{array}{l}11.646 \\
{[0.070]}\end{array}$ & $\begin{array}{l}14.863 \\
{[0.021]}\end{array}$ & $\begin{array}{l}12.502 \\
{[0.052]}\end{array}$ & $\begin{array}{l}13.877 \\
{[0.031]}\end{array}$ & $\begin{array}{c}0.433 \\
(0.244)\end{array}$ & $\begin{array}{c}0.494 \\
(0.228)\end{array}$ & $\begin{array}{c}0.494 \\
(0.239)\end{array}$ & $\begin{array}{c}1.056 \\
(0.413)\end{array}$ & $\begin{array}{c}1.087 \\
(0.458)\end{array}$ & $\begin{array}{r}1.031 \\
(0.420)\end{array}$ \\
\hline Korea & $\begin{array}{c}2.821 \\
{[0.831]}\end{array}$ & $\begin{array}{l}23.956 \\
{[0.001]}\end{array}$ & $\begin{array}{l}11.512 \\
{[0.074]}\end{array}$ & $\begin{array}{l}21.970 \\
{[0.001]}\end{array}$ & $\begin{array}{l}11.607 \\
{[0.071]}\end{array}$ & {$\left[\begin{array}{l}24.764 \\
{[<0.000]}\end{array}\right.$} & $\begin{array}{c}0.953 \\
(0.277)\end{array}$ & $\begin{array}{c}1.049 \\
(0.311)\end{array}$ & $\begin{array}{c}1.023 \\
(0.277)\end{array}$ & $\begin{array}{c}1.835 \\
(1.101)\end{array}$ & $\begin{array}{c}2.161 \\
(1.321)\end{array}$ & $\begin{array}{r}2.039 \\
(1.119)\end{array}$ \\
\hline Malaysia & $\begin{array}{c}3.891 \\
{[0.691]}\end{array}$ & $\begin{array}{l}12.550 \\
{[0.051]}\end{array}$ & $\begin{array}{l}11.279 \\
{[0.080]}\end{array}$ & $\begin{array}{c}3.323 \\
{[0.767]}\end{array}$ & $\begin{array}{c}3.664 \\
{[0.722]}\end{array}$ & $\begin{array}{c}0.658 \\
{[0.995]}\end{array}$ & $\begin{array}{c}-0.944 \\
(0.514)\end{array}$ & $\begin{array}{c}-1.049 \\
(0.507)\end{array}$ & $\begin{array}{c}-0.914 \\
(0.481)\end{array}$ & $\begin{array}{c}2.550 \\
(1.620)\end{array}$ & $\begin{array}{c}2.818 \\
(1.699)\end{array}$ & $\begin{array}{r}2.282 \\
(1.558)\end{array}$ \\
\hline Mexico & {$[<0.000]$} & $\stackrel{27.227}{[<0.000]}$ & $\begin{array}{c}24.375 \\
{[<0.000]}\end{array}$ & {$\left[\begin{array}{l}55.601 \\
{[<0.000]}\end{array}\right.$} & $\begin{array}{c}47.891 \\
{[<0.000]}\end{array}$ & $\stackrel{56.811}{\mid<0.000]}$ & $\begin{array}{c}-0.719 \\
(0.483)\end{array}$ & $\begin{array}{c}-0.860 \\
(0.523)\end{array}$ & $\begin{array}{c}-0.718 \\
(0.484)\end{array}$ & $\begin{array}{c}3.518 \\
(1.053)\end{array}$ & $\begin{array}{c}4.253 \\
(1.146)\end{array}$ & $\begin{array}{r}3.523 \\
(1.058)\end{array}$ \\
\hline Nigeria & $\begin{array}{c}4774.80 \\
{[<0.000]}\end{array}$ & $\begin{array}{c}371.610 \\
{[<0.000]}\end{array}$ & $\begin{array}{c}67.531 \\
{[<0.000]}\end{array}$ & $\begin{array}{c}1.053 \\
{[0.984]}\end{array}$ & $\begin{array}{l}1.068 \\
{[0.983]}\end{array}$ & $\begin{array}{c}1.111 \\
{[0.981]}\end{array}$ & $\begin{array}{c}-1.612 \\
(1.005)\end{array}$ & $\begin{array}{c}-1.562 \\
(1.109)\end{array}$ & $\begin{array}{c}-1.457 \\
(1.090)\end{array}$ & $\begin{array}{c}9.540 \\
(3.144)\end{array}$ & $\begin{array}{c}10.232 \\
(3.534)\end{array}$ & $\begin{array}{r}9.630 \\
(3.158)\end{array}$ \\
\hline Pakistan & $\begin{array}{c}2199.40 \\
{[<0.000]}\end{array}$ & $\begin{array}{c}2472.20 \\
{[<0.000]}\end{array}$ & $\begin{array}{c}1963.90 \\
{[<0.000]}\end{array}$ & {$\left[\begin{array}{l}29.949 \\
{[<0.000]}\end{array}\right.$} & $\stackrel{28.563}{[<0.000]}$ & $\stackrel{27.636}{[<0.000]}$ & $\begin{array}{c}2.237 \\
(0.487)\end{array}$ & $\begin{array}{c}2.110 \\
(0.562)\end{array}$ & $\begin{array}{c}1.821 \\
(0.641)\end{array}$ & $\begin{array}{c}8.453 \\
(3.338)\end{array}$ & $\begin{array}{c}8.692 \\
(3.456)\end{array}$ & $\begin{array}{r}8.221 \\
(3.250)\end{array}$ \\
\hline Philippines & $\begin{array}{l}11.027 \\
{[0.088]}\end{array}$ & $\begin{array}{c}7.804 \\
{[0.253]}\end{array}$ & $\begin{array}{c}3.372 \\
{[0.761]}\end{array}$ & $\begin{array}{c}2.864 \\
{[0.826]}\end{array}$ & $\begin{array}{c}2.609 \\
{[0.856]}\end{array}$ & $\begin{array}{c}2.891 \\
{[0.822]}\end{array}$ & $\begin{array}{c}0.564 \\
(0.416)\end{array}$ & $\begin{array}{c}0.591 \\
(0.444)\end{array}$ & $\begin{array}{c}0.696 \\
(0.363)\end{array}$ & $\begin{array}{c}1.822 \\
(0.972)\end{array}$ & $\begin{array}{c}2.173 \\
(1.018)\end{array}$ & $\begin{array}{r}1.983 \\
(0.909)\end{array}$ \\
\hline Portugal & $\begin{array}{c}9.223 \\
{[0.161]}\end{array}$ & $\begin{array}{c}9.229 \\
{[0.161]}\end{array}$ & $\begin{array}{c}9.228 \\
{[0.161]}\end{array}$ & $\begin{array}{l}14.544 \\
{[0.024]}\end{array}$ & $\begin{array}{l}14.539 \\
{[0.024]}\end{array}$ & $\begin{array}{l}14.540 \\
{[0.024]}\end{array}$ & $\begin{array}{c}1.798 \\
(0.577)\end{array}$ & $\begin{array}{c}1.798 \\
(0.577)\end{array}$ & $\begin{array}{c}1.798 \\
(0.577)\end{array}$ & $\begin{array}{c}6.950 \\
(2.625)\end{array}$ & $\begin{array}{c}6.951 \\
(2.625)\end{array}$ & $\begin{array}{r}6.951 \\
(2.625)\end{array}$ \\
\hline Taiwan & $\left\{\begin{array}{l}145.360 \\
\{<0.000\}\end{array}\right.$ & $\begin{array}{c}328.250 \\
{[<0.000]}\end{array}$ & $\begin{array}{c}2.642 \\
{[0.852]}\end{array}$ & $\begin{array}{l}19.336 \\
{[0.004]}\end{array}$ & $\begin{array}{l}19.415 \\
{[0.004]}\end{array}$ & $\begin{array}{l}18.478 \\
{[0.005]}\end{array}$ & $\begin{array}{c}-0.079 \\
(0.267)\end{array}$ & $\begin{array}{c}-0.206 \\
(0.333)\end{array}$ & $\begin{array}{c}0.175 \\
(0.274)\end{array}$ & $\begin{array}{c}0.636 \\
(0.562)\end{array}$ & $\begin{array}{c}1.029 \\
(0.773)\end{array}$ & $\begin{array}{r}0.550 \\
(0.506)\end{array}$ \\
\hline Thailand & $\begin{array}{c}916.870 \\
K<0.000]\end{array}$ & $\begin{array}{c}2423.00 \\
{[<0.000]}\end{array}$ & $\begin{array}{l}137.060 \\
{[<0.000]}\end{array}$ & $\begin{array}{l}10.467 \\
{[0.106]}\end{array}$ & {$[0.090]$} & $\begin{array}{l}10.474 \\
{[0.106]}\end{array}$ & $\begin{array}{c}-0.457 \\
(0.644)\end{array}$ & $\begin{array}{c}-0.464 \\
(0.647)\end{array}$ & $\begin{array}{c}-0.287 \\
(0.632)\end{array}$ & $\begin{array}{c}4.307 \\
(2.134)\end{array}$ & $\begin{array}{c}4.342 \\
(2.145)\end{array}$ & $\begin{array}{r}3.771 \\
(2.037)\end{array}$ \\
\hline Turkey & $\begin{array}{c}5.586 \\
{[0.471]}\end{array}$ & $\begin{array}{c}24.575 \\
{[<0.000]}\end{array}$ & $\begin{array}{c}52.331 \\
{[<0.000]}\end{array}$ & $\begin{array}{c}5.273 \\
{[0.509]}\end{array}$ & $\begin{array}{c}6.850 \\
{[0.335]}\end{array}$ & $\begin{array}{c}9.772 \\
{[0.135]}\end{array}$ & $\begin{array}{c}0.794 \\
(0.306)\end{array}$ & $\begin{array}{c}0.938 \\
(0.331)\end{array}$ & $\begin{array}{c}1.167 \\
(0.348)\end{array}$ & $\begin{array}{c}0.537 \\
(0.867)\end{array}$ & $\begin{array}{c}0.845 \\
(1.034)\end{array}$ & $\begin{array}{r}1.469 \\
(1.291)\end{array}$ \\
\hline Venezuela & $\begin{array}{c}8.871 \\
{[0.181]}\end{array}$ & $\begin{array}{c}8.110 \\
{[0.230]}\end{array}$ & $\begin{array}{c}3.211 \\
{[0.782]}\end{array}$ & $\begin{array}{c}7.881 \\
{[0.247]}\end{array}$ & $\begin{array}{c}8.060 \\
{[0.234]}\end{array}$ & $\begin{array}{c}5.937 \\
{[0.430]}\end{array}$ & $\begin{array}{c}0.000 \\
(0.372)\end{array}$ & $\begin{array}{c}0.011 \\
(0.373)\end{array}$ & $\begin{array}{c}0.059 \\
(0.334)\end{array}$ & $\begin{array}{c}1.378 \\
(0.670)\end{array}$ & $\begin{array}{c}1.395 \\
(0.673)\end{array}$ & $\begin{array}{r}1.118 \\
(0.544)\end{array}$ \\
\hline Zinibabwe & $\begin{array}{l}14.820 \\
{[0.022]} \\
\end{array}$ & $\begin{array}{l}11.693 \\
{[0.069]} \\
\end{array}$ & $\begin{array}{l}12.150 \\
{[0.059]}\end{array}$ & $\begin{array}{c}7.410 \\
{[0.285]}\end{array}$ & $\begin{array}{c}6.973 \\
{[0.323]} \\
\end{array}$ & $\begin{array}{c}7.207 \\
{[0.302]} \\
\end{array}$ & $\begin{array}{c}0.145 \\
(0.381) \\
\end{array}$ & $\begin{array}{c}0.163 \\
(0.391) \\
\end{array}$ & $\begin{array}{c}0.155 \\
(0.393) \\
\end{array}$ & $\begin{array}{c}1.634 \\
(1.047)\end{array}$ & $\begin{array}{c}1.728 \\
(1.097)\end{array}$ & $\begin{array}{r}1.732 \\
(1.097)\end{array}$ \\
\hline
\end{tabular}


B. Tests on standardized residuals, $\hat{\epsilon}_{t} / \hat{\sigma}_{t}$

\begin{tabular}{|c|c|c|c|c|c|c|c|c|c|c|c|c|}
\hline \multirow[b]{2}{*}{ Country } & \multicolumn{3}{|c|}{$\begin{array}{c}\text { Mean test } \\
\chi^{2}(k)\end{array}$} & \multicolumn{3}{|c|}{$\begin{array}{c}\text { Moment test } \\
\chi^{2}(4)\end{array}$} & \multicolumn{3}{|c|}{$\begin{array}{l}\text { Variance test } \\
\qquad \chi^{2}(k)\end{array}$} & \multicolumn{3}{|c|}{$\begin{array}{c}\text { Joilnt } \\
\chi^{2}(2 \ddot{k}+4)\end{array}$} \\
\hline & 1 & II & III & $\mathrm{I}$ & II & III & 1 & II & III & $\mathrm{I}$ & II & III \\
\hline Argentina & $\begin{array}{c}4.825 \\
{[0.567]}\end{array}$ & $\bar{a}$ & $\begin{array}{c}3.396 \\
{[0.758]}\end{array}$ & {$\left[\begin{array}{c}77.537 \\
{[<0.000]}\end{array}\right.$} & $\bar{a}$ & $\begin{array}{l}10.890 \\
{[0.028]}\end{array}$ & $\begin{array}{c}7.457 \\
{[0.281]}\end{array}$ & $a$ & $\begin{array}{l}10.089 \\
{[0.121]}\end{array}$ & $\begin{array}{c}111.245 \\
{[<0.000]}\end{array}$ & $\bar{a}$ & $\begin{array}{l}19.640 \\
{[0.237]}\end{array}$ \\
\hline Brazil & $\begin{array}{l}1.310 \\
{[0.971]}\end{array}$ & $\begin{array}{c}1.502 \\
{[0.959]}\end{array}$ & $\begin{array}{c}1.296 \\
{[0.972]}\end{array}$ & $\begin{array}{c}5.408 \\
{[0.248]}\end{array}$ & $\begin{array}{l}11.347 \\
{[0.023]}\end{array}$ & $\begin{array}{l}16.383 \\
{[0.003]}\end{array}$ & $\begin{array}{l}10.006 \\
{[0.124]}\end{array}$ & $\begin{array}{c}9.209 \\
{[0.162]}\end{array}$ & $\begin{array}{l}11.216 \\
{[0.082]}\end{array}$ & $\begin{array}{l}23.690 \\
{[0.097]}\end{array}$ & $\begin{array}{l}39.922 \\
{[0.001]}\end{array}$ & {$\left[\begin{array}{c}49.686 \\
{[<0.000]}\end{array}\right.$} \\
\hline Chile & $\begin{array}{l}10.305 \\
{[0.112]}\end{array}$ & $\begin{array}{l}10.661 \\
{[0.099]}\end{array}$ & $\begin{array}{l}10.739 \\
{[0.097]}\end{array}$ & $\begin{array}{c}1.520 \\
{[0.823]}\end{array}$ & $\begin{array}{c}4.193 \\
{[0.381]}\end{array}$ & $\begin{array}{c}1.828 \\
{[0.767]}\end{array}$ & $\begin{array}{c}2.971 \\
{[0.813]}\end{array}$ & $\begin{array}{c}5.643 \\
{[0.464]}\end{array}$ & $\begin{array}{c}6.174 \\
{[0.404]}\end{array}$ & $\begin{array}{l}18.100 \\
{[0.318]}\end{array}$ & $\begin{array}{l}21.960 \\
{[0.145]}\end{array}$ & $\begin{array}{l}18.192 \\
{[0.313]}\end{array}$ \\
\hline Colombia & $\begin{array}{c}3.530 \\
{[0.740]}\end{array}$ & \multirow{2}{*}{ a } & $\begin{array}{c}2.643 \\
{[0.852]}\end{array}$ & {$\left[\begin{array}{l}21.299 \\
{[<0.000]}\end{array}\right.$} & \multirow{2}{*}{ a } & $\begin{array}{c}7.497 \\
{[0.112]}\end{array}$ & $\begin{array}{c}4.554 \\
{[0.602]}\end{array}$ & \multirow{2}{*}{ a } & $\begin{array}{c}3.778 \\
{[0.707]}\end{array}$ & $\begin{array}{c}112.424 \\
{[<0.000]}\end{array}$ & \multirow{2}{*}{$a$} & $\begin{array}{l}26.664 \\
{[0.045]}\end{array}$ \\
\hline Greece & $\begin{array}{l}16.376 \\
{[0.012]}\end{array}$ & & $\begin{array}{c}5.269 \\
{[0.510]}\end{array}$ & $\stackrel{21.707}{[<0.000]}$ & & $\begin{array}{c}5.063 \\
{[0.281]}\end{array}$ & $\begin{array}{c}7.712 \\
{[0.260]}\end{array}$ & & $\begin{array}{c}9.080 \\
{[0.169]}\end{array}$ & {$\left[\begin{array}{l}85.721 \\
{[<0.000]}\end{array}\right.$} & & $\begin{array}{l}20.719 \\
{[0.190]}\end{array}$ \\
\hline India & $\begin{array}{c}4.217 \\
{[0.647]}\end{array}$ & $\begin{array}{c}5.035 \\
{[0.539]}\end{array}$ & $\begin{array}{c}4.691 \\
{[0.584]}\end{array}$ & $\begin{array}{c}8.110 \\
{[0.088]}\end{array}$ & $\begin{array}{c}150.672 \\
{[<0.000]}\end{array}$ & $\begin{array}{c}512.382 \\
{[<0.000]}\end{array}$ & $\begin{array}{c}8.331 \\
{[0.215]}\end{array}$ & $\begin{array}{c}7.623 \\
{[0.267]}\end{array}$ & $\begin{array}{c}7.397 \\
{[0.286]}\end{array}$ & $\begin{array}{l}34.719 \\
{[0.004]}\end{array}$ & $\begin{array}{c}271.380 \\
{[<0.000]}\end{array}$ & $\begin{array}{c}1130.90 \\
{[<0.000]}\end{array}$ \\
\hline Indonesia & $\begin{array}{c}8.544 \\
{[0.201]}\end{array}$ & $\begin{array}{c}8.545 \\
{[0.201]}\end{array}$ & {$\left[\begin{array}{c}26.899 \\
{[<0.000]}\end{array}\right.$} & $\begin{array}{c}203.688 \\
{[<0.000]}\end{array}$ & $\begin{array}{c}203.772 \\
{[<0.000]}\end{array}$ & $\begin{array}{c}0.901 \\
{[0.925]}\end{array}$ & $\begin{array}{l}22.633 \\
{[0.001]}\end{array}$ & $\begin{array}{l}22.633 \\
{[0.001]}\end{array}$ & $\begin{array}{c}4.865 \\
{[0.561]}\end{array}$ & $\begin{array}{c}3723.09 \\
{[<0.000]}\end{array}$ & $\begin{array}{c}3724.64 \\
{[<0.000]}\end{array}$ & {$[<0.000]$} \\
\hline Jordan & $\begin{array}{l}11.523 \\
{[0.074]}\end{array}$ & $\begin{array}{c}9.707 \\
{[0.138]}\end{array}$ & $\begin{array}{l}10.976 \\
{[0.089]}\end{array}$ & $\begin{array}{c}8.296 \\
{[0.081]}\end{array}$ & $\begin{array}{c}402.596 \\
{[<0.000]}\end{array}$ & {$\left[\begin{array}{c}26.834 \\
{[<0.000]}\end{array}\right.$} & $\begin{array}{c}7.071 \\
{[0.314]}\end{array}$ & $\begin{array}{c}6.319 \\
{[0.388]}\end{array}$ & $\begin{array}{c}6.730 \\
{[0.347]}\end{array}$ & $\begin{array}{c}43.700 \\
{[<0.000]}\end{array}$ & $\begin{array}{c}591.162 \\
{[<0.000]}\end{array}$ & {$\left[\begin{array}{l}55.947 \\
{[<0.000]}\end{array}\right.$} \\
\hline Korea & $\begin{array}{c}0.463 \\
{[0.998]}\end{array}$ & $\begin{array}{c}0.941 \\
{[0.988]}\end{array}$ & $\begin{array}{c}0.831 \\
{[0.991]}\end{array}$ & {$[<0.000]$} & $\begin{array}{c}188.642 \\
{[<0.000]}\end{array}$ & $\begin{array}{c}5.627 \\
{[0.229]}\end{array}$ & $\begin{array}{c}3.034 \\
{[0.805]}\end{array}$ & $\begin{array}{c}3.235 \\
{[0.779]}\end{array}$ & $\begin{array}{c}1.998 \\
{[0.920]}\end{array}$ & $\begin{array}{l}37.035 \\
{[0.002]}\end{array}$ & $\stackrel{231.450}{[<0.000]}$ & $\begin{array}{l}28.231 \\
{[0.030]}\end{array}$ \\
\hline Malaysia & $\begin{array}{c}7.194 \\
{[0.303]}\end{array}$ & $\begin{array}{c}7.532 \\
{[0.275]}\end{array}$ & $b$ & $\begin{array}{l}16.789 \\
{[0.002]}\end{array}$ & {$\left[\begin{array}{c}37.900 \\
{[<0.000]}\end{array}\right.$} & $b$ & $\begin{array}{c}2.556 \\
{[0.862]}\end{array}$ & $\begin{array}{l}1.488 \\
{[0.960]}\end{array}$ & b & $\begin{array}{l}35.870 \\
{[0.003]}\end{array}$ & {$[<0.000]$} & b \\
\hline Mexico & $\begin{array}{c}3.272 \\
{[0.774]}\end{array}$ & $\begin{array}{c}2.245 \\
{[0.896]}\end{array}$ & $b$ & $\begin{array}{c}4.944 \\
{[0.293]}\end{array}$ & {$[<0.000]$} & 6 & $\begin{array}{c}3.824 \\
{[0.700]}\end{array}$ & $\begin{array}{c}3.741 \\
{[0.712]}\end{array}$ & $b$ & $\begin{array}{l}18.879 \\
{[0.275]}\end{array}$ & {$[<0.000]$} & b \\
\hline Nigeria & $\begin{array}{c}5.291 \\
{[0.507]}\end{array}$ & $a$ & $\begin{array}{c}3.925 \\
{[0.687]}\end{array}$ & $\begin{array}{c}9.434 \\
{[0.051]}\end{array}$ & $a$ & $\begin{array}{l}18.846 \\
{[0.001]}\end{array}$ & $\begin{array}{c}4.224 \\
{[0.646]}\end{array}$ & $a$ & $\begin{array}{c}5.302 \\
{[0.506]}\end{array}$ & $\begin{array}{l}27.385 \\
{[0.037]}\end{array}$ & a & $\begin{array}{c}83.058 \\
{[<0.000]}\end{array}$ \\
\hline Pakistan & $\begin{array}{c}7.965 \\
{[0.241]}\end{array}$ & $a$ & $\begin{array}{c}8.117 \\
{[0.230]}\end{array}$ & {$\left[\begin{array}{c}53.290 \\
{[<0.000}\end{array}\right]$} & $a$ & $\begin{array}{l}12.077 \\
{[0.017]}\end{array}$ & $\begin{array}{c}5.037 \\
{[0.539]}\end{array}$ & $a$ & $\begin{array}{c}7.395 \\
{[0.286]}\end{array}$ & {$\left[\begin{array}{c}88.648 \\
{[<0.000]}\end{array}\right.$} & $a$ & $\begin{array}{c}326.684 \\
{[<0.000]}\end{array}$ \\
\hline Philippines & $\begin{array}{c}3.107 \\
{[0.795]}\end{array}$ & $a$ & $\begin{array}{c}6.026 \\
{[0.420]}\end{array}$ & $\begin{array}{c}2.535 \\
{[0.638]}\end{array}$ & $a$ & $\begin{array}{c}640.443 \\
{[<0.000]}\end{array}$ & $\begin{array}{c}6.545 \\
{[0.365]}\end{array}$ & $a$ & $\begin{array}{c}2.615 \\
{[0.855]}\end{array}$ & $\begin{array}{l}28.499 \\
{[0.028]}\end{array}$ & $a$ & $\begin{array}{l}1297.17 \\
{[<0.000]}\end{array}$ \\
\hline Portugal & $\begin{array}{c}3.612 \\
{[0.729]}\end{array}$ & $\begin{array}{c}3.613 \\
{[0.729]}\end{array}$ & {$\left[\begin{array}{l}3.612 \\
{[0.729]}\end{array}\right.$} & $\begin{array}{c}4.322 \\
{[0.364]}\end{array}$ & $\begin{array}{c}4.317 \\
{[0.365]}\end{array}$ & $\begin{array}{c}4.325 \\
{[0.364]}\end{array}$ & $\begin{array}{c}2.563 \\
{[0.861]}\end{array}$ & $\begin{array}{c}2.563 \\
{[0.861]}\end{array}$ & $\begin{array}{c}2.564 \\
{[0.861]}\end{array}$ & $\begin{array}{l}13.929 \\
{[0.604]}\end{array}$ & $\begin{array}{l}13.925 \\
{[0.604]}\end{array}$ & $\begin{array}{l}13.932 \\
{[0.604]}\end{array}$ \\
\hline Taiwan & $\begin{array}{c}2.985 \\
{[0.811]}\end{array}$ & $\begin{array}{c}3.316 \\
{[0.768]}\end{array}$ & $b$ & $\begin{array}{c}4.560 \\
{[0.336]}\end{array}$ & $\begin{array}{c}142.646 \\
{[<0.000]}\end{array}$ & b & $\begin{array}{c}2.782 \\
{[0.836]}\end{array}$ & 2.854 & $\begin{array}{c}b \\
{[0.196]}\end{array}$ & $\begin{array}{l}15.664 \\
{[0.477]}\end{array}$ & $\begin{array}{c}294.666 \\
{[<0.000]}\end{array}$ & b \\
\hline Thailand & $\begin{array}{c}7.321 \\
{[0.292]}\end{array}$ & $\begin{array}{c}6.757 \\
{[0.344]}\end{array}$ & $\begin{array}{c}7.149 \\
{[0.307]}\end{array}$ & $\begin{array}{c}7.740 \\
{[0.102]}\end{array}$ & $\begin{array}{c}109.465 \\
{[<0.000]}\end{array}$ & $\begin{array}{c}5.983 \\
{[0.200]}\end{array}$ & $\begin{array}{c}4.256 \\
{[0.642]}\end{array}$ & $\begin{array}{c}3.944 \\
{[0.684]}\end{array}$ & $\begin{array}{c}4.769 \\
{[0.574]}\end{array}$ & $\begin{array}{l}28.052 \\
{[0.031]}\end{array}$ & $\begin{array}{c}305.296 \\
{[<0.000]}\end{array}$ & $\begin{array}{l}20.934 \\
{[0.181]}\end{array}$ \\
\hline Turkey & $\begin{array}{c}4.806 \\
{[0.569]}\end{array}$ & $a$ & $\begin{array}{c}3.511 \\
{[0.743]}\end{array}$ & {$\left[\begin{array}{c}21.011 \\
{[<0.000]}\end{array}\right.$} & 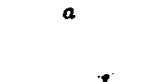 & $\begin{array}{l}18.566 \\
{[0.001]}\end{array}$ & $\begin{array}{c}8.382 \\
{[0.212]}\end{array}$ & $a$ & $\begin{array}{l}8.205 \\
{[0.224]}\end{array}$ & $\begin{array}{l}53.647 \\
{[<0.000]}\end{array}$ & $a$ & {$\left[\begin{array}{c}67.944 \\
{[<0.000]}\end{array}\right.$} \\
\hline Venezuela & $\begin{array}{c}3.879 \\
{[0.693]}\end{array}$ & $\begin{array}{c}3.748 \\
{[0.711]}\end{array}$ & $\begin{array}{l}2.516 \\
{[0.867]}\end{array}$ & $\begin{array}{l}1.182 \\
{[0.881]}\end{array}$ & $\begin{array}{c}3.061^{\circ} \\
{[0.548]}\end{array}$ & {$[<0.000]$} & $\begin{array}{l}10.547 \\
{[0.103]}\end{array}$ & $\begin{array}{l}10.716 \\
{[0.098]}\end{array}$ & $\begin{array}{c}3.497 \\
{[0.744]}\end{array}$ & $\begin{array}{l}25.672 \\
{[0.059]}\end{array}$ & $\begin{array}{l}34.511 \\
{[0.005]}\end{array}$ & $\begin{array}{l}41.349 \\
{[0.001]}\end{array}$ \\
\hline Zimbabwe & $\begin{array}{l}16.769 \\
{[0.010]} \\
\end{array}$ & $\begin{array}{l}16.078 \\
{[0.013]} \\
\end{array}$ & $\begin{array}{l}16.448 \\
{[0.012]}\end{array}$ & $\begin{array}{c}5.161 \\
{[0.271]} \\
\end{array}$ & $\begin{array}{c}2.336 \\
{[0.674]}\end{array}$ & $\begin{array}{c}2.055 \\
{[0.726]}\end{array}$ & $\begin{array}{c}6.664 \\
{[0.353]}\end{array}$ & $\begin{array}{c}6.878 \\
{[0.332]}\end{array}$ & $\begin{array}{c}7.362 \\
{[0.289]}\end{array}$ & $\begin{array}{l}38.607 \\
{[0.001]}\end{array}$ & $\begin{array}{c}44.127 \\
{[<0.000]}\end{array}$ & $\begin{array}{l}41.231 \\
{[0.001]}\end{array}$ \\
\hline
\end{tabular}

${ }^{a}$ In $t$-distribution model, the degrees of freedom parameter, $\nu<4$.

${ }^{b}$ In SPARCIl estimation, the mixing parameter, $p=1$.

${ }^{c}$ Did not converge. 
Appendix Table A3

Asymmetric effects in conditional variances

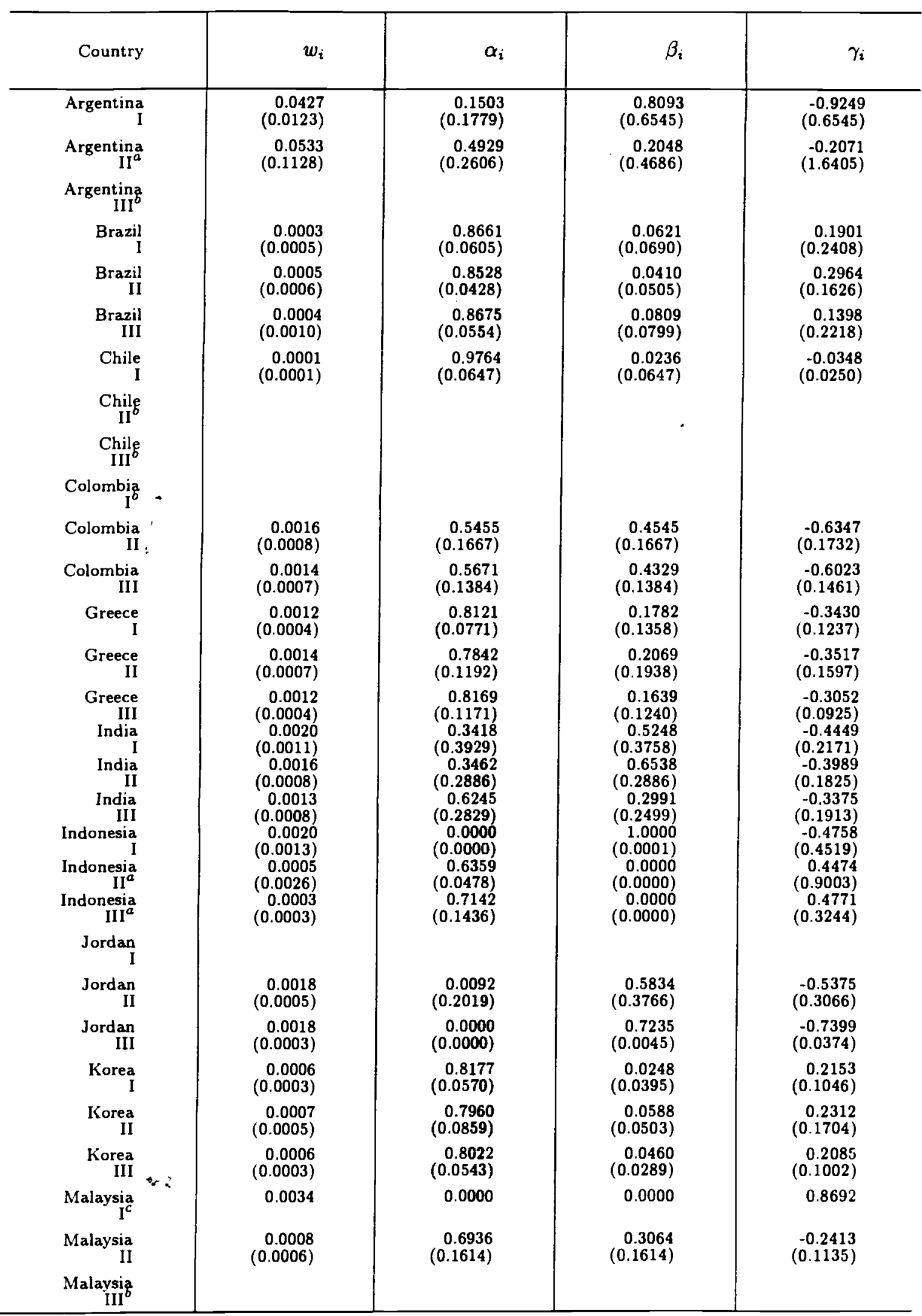


Appendix Table A3 (continued)

\begin{tabular}{|c|c|c|c|c|c|}
\hline Country & & $w_{i}$ & $\alpha_{i}$ & $\beta_{i}$ & $\gamma_{i}$ \\
\hline $\begin{array}{r}\text { Mexico } \\
\text { I }\end{array}$ & & $\begin{array}{r}0.0018 \\
(0.0004)\end{array}$ & $\begin{array}{r}0.6285 \\
(0.0121)\end{array}$ & $\begin{array}{r}0.3561 \\
(0.0121)\end{array}$ & $\begin{array}{r}-0.1660 \\
(0.0635)\end{array}$ \\
\hline $\begin{array}{r}\text { Mexico } \\
\text { II }\end{array}$ & & $\begin{array}{r}0.0033 \\
(0.0016)\end{array}$ & $\begin{array}{r}0.4985 \\
(0.1705)\end{array}$ & $\begin{array}{r}0.2545 \\
(0.1780)\end{array}$ & $\begin{array}{r}0.0729 \\
(0.2471)\end{array}$ \\
\hline $\begin{array}{l}\text { Mexico } \\
\text { III }^{a}\end{array}$ & & $\begin{array}{r}0.0022 \\
(0.0005)\end{array}$ & $\begin{array}{r}0.6345 \\
(0.0000)\end{array}$ & $\begin{array}{r}0.3655 \\
(0.0000)\end{array}$ & $\begin{array}{r}-0.1447 \\
(0.0645)\end{array}$ \\
\hline $\begin{array}{r}\text { Nigeria } \\
\text { I }\end{array}$ & & $\begin{array}{r}0.0010 \\
(0.0007)\end{array}$ & $\begin{array}{r}0.1590 \\
(0.0585)\end{array}$ & $\begin{array}{r}0.2161 \\
(0.6781)\end{array}$ & $\begin{array}{r}3.1077 \\
(1.9250)\end{array}$ \\
\hline$\underset{I^{2}}{\text { Nigeria }}$ & & $\begin{array}{r}0.0236 \\
(0.1352)\end{array}$ & $\begin{array}{r}0.2358 \\
(0.2817)\end{array}$ & $\begin{array}{r}0.3231 \\
(13.2970)\end{array}$ & $\begin{array}{r}33.4511 \\
(180.7950)\end{array}$ \\
\hline $\begin{array}{r}\text { Nigerig } \\
\text { III } \\
\text { Pakistan } \\
I^{b} \\
\text { Pakistan } \\
\text { II }^{b}\end{array}$ & & $\begin{array}{r}0.0013 \\
(0.0004)\end{array}$ & $\begin{array}{r}0.2008 \\
(0.0424)\end{array}$ & $\begin{array}{r}0.0000 \\
(0.0000)\end{array}$ & $\begin{array}{r}2.9608 \\
(1.0949)\end{array}$ \\
\hline $\begin{array}{r}\text { Pakistan } \\
\text { III }\end{array}$ & & $\begin{array}{r}0.0002 \\
(0.0001)\end{array}$ & $\begin{array}{r}0.8390 \\
(0.0000)\end{array}$ & $\begin{array}{r}0.1610 \\
(0.0000)\end{array}$ & $\begin{array}{r}-0.2814 \\
(0.0832)\end{array}$ \\
\hline $\begin{array}{r}\text { Philippines } \\
\text { I }\end{array}$ & & $\begin{array}{r}0.0068 \\
(0.0015)\end{array}$ & $\begin{array}{r}0.0000 \\
(0.0000)\end{array}$ & $\begin{array}{r}0.0000 \\
(0.0000)\end{array}$ & $\begin{array}{r}0.9088 \\
(0.6447)\end{array}$ \\
\hline $\begin{array}{l}\text { Philippines } \\
\text { II }^{\mathbf{a}}\end{array}$ & + & $\begin{array}{r}0.0076 \\
(0.0017)\end{array}$ & $\begin{array}{r}0.0000 \\
(0.0000)\end{array}$ & $\begin{array}{r}0.0000 \\
(0.0000)\end{array}$ & $\begin{array}{r}0.8677 \\
(0.0501)\end{array}$ \\
\hline $\begin{array}{l}\text { Philippines } \\
\text { III }^{b}\end{array}$ & $:$ & $\begin{array}{r}0.0078 \\
(0.0020)\end{array}$ & $\begin{array}{r}0.0000 \\
(0.0000)\end{array}$ & $\begin{array}{r}0.0000 \\
(0.0000)\end{array}$ & $\begin{array}{r}0.7958 \\
(0.7125)\end{array}$ \\
\hline Portugal & & $\begin{array}{r}0.0024 \\
(0.0008)\end{array}$ & $\begin{array}{r}0.0002 \\
(0.0000)\end{array}$ & $\begin{array}{r}0.9998 \\
(0.0000)\end{array}$ & $\begin{array}{r}-0.2670 \\
(0.2602)\end{array}$ \\
\hline $\begin{array}{l}\text { Portugal } \\
\text { II } \\
\text { Portugal } \\
\text { III }\end{array}$ & & & & & \\
\hline $\begin{array}{r}\text { Taiwan } \\
\text { I }\end{array}$ & & $\begin{array}{r}0.0031 \\
(0.0018)\end{array}$ & $\begin{array}{r}0.5447 \\
(0.0000)\end{array}$ & $\begin{array}{r}0.4553 \\
(0.0000)\end{array}$ & $\begin{array}{r}-0.2564 \\
(0.1124)\end{array}$ \\
\hline $\begin{array}{r}\text { Taiwan } \\
\text { II }\end{array}$ & & $\begin{array}{r}0.0017 \\
(0.0022)\end{array}$ & $\begin{array}{r}0.6490 \\
(0.1534)\end{array}$ & $\begin{array}{r}0.3510 \\
(0.1534)\end{array}$ & $\begin{array}{r}0.0027 \\
(0.6906)\end{array}$ \\
\hline $\begin{array}{r}\text { Taiwan } \\
\text { III }\end{array}$ & & $\begin{array}{r}0.0063 \\
(0.0030)\end{array}$ & $\begin{array}{r}0.3939 \\
(0.0783)\end{array}$ & $\begin{array}{r}0.2212 \\
(0.0937)\end{array}$ & $\begin{array}{r}0.4779 \\
(0.4278)\end{array}$ \\
\hline $\begin{array}{r}\text { Thailand } \\
\text { I }\end{array}$ & & $\begin{array}{r}0.0014 \\
(0.0007)\end{array}$ & $\begin{array}{r}0.4655 \\
(0.1608)\end{array}$ & $\begin{array}{r}0.5060 \\
(0.2094)\end{array}$ & $\begin{array}{r}-0.4326 \\
(0.2036)\end{array}$ \\
\hline $\begin{array}{r}\text { Thailand } \\
\text { II }\end{array}$ & & $\begin{array}{r}0.0010 \\
(0.0003)\end{array}$ & $\begin{array}{r}0.5971 \\
(0.0038)\end{array}$ & $\begin{array}{r}0.3903 \\
(0.0038)\end{array}$ & $\begin{array}{r}-0.2998 \\
(0.0783)\end{array}$ \\
\hline $\begin{array}{r}\text { Thailand } \\
\text { III } \\
\text { Turkey } \\
\text { I }^{6} \\
\text { Turkey } \\
\text { II }^{6} \\
\text { Turkey } \\
\text { III }^{6}\end{array}$ & & $\begin{array}{r}0.0019 \\
(0.0011)\end{array}$ & $\begin{array}{r}0.4072 \\
(0.2523)\end{array}$ & $\begin{array}{r}0.5022 \\
(0.3147)\end{array}$ & $\begin{array}{r}-0.5113 \\
(0.3008)\end{array}$ \\
\hline$\underset{I^{\mathbf{a}}}{\text { Venezuela }}$ & & $\begin{array}{r}0.0078 \\
(0.0023)\end{array}$ & $\begin{array}{r}0.0000 \\
(0.0000)\end{array}$ & $\begin{array}{r}1.0000 \\
(0.0000)\end{array}$ & $\begin{array}{r}-1.0009 \\
(0.1223)\end{array}$ \\
\hline $\begin{array}{c}\text { Venezuela } \\
I^{\delta}\end{array}$ & & & & & \\
\hline$\underset{\text { III }^{b}}{\text { Venezuela }}$ & $8 ?$ & & & & \\
\hline $\begin{array}{r}\text { Zimbabwe } \\
\text { I }\end{array}$ & & $\begin{array}{r}0.0003 \\
(0.0001)\end{array}$ & $\begin{array}{r}0.9107 \\
(0.0029)\end{array}$ & $\begin{array}{r}0.0000 \\
(0.0000)\end{array}$ & $\begin{array}{r}0.1079 \\
(0.0325)\end{array}$ \\
\hline $\begin{array}{r}\text { Zimbabwe } \\
\text { II }\end{array}$ & & $\begin{array}{r}0.0004 \\
(0.0003)\end{array}$ & $\begin{array}{r}0.8877 \\
(0.0456)\end{array}$ & $\begin{array}{r}0.0000 \\
(0.0000)\end{array}$ & $\begin{array}{r}0.1275 \\
(0.0525)\end{array}$ \\
\hline $\begin{array}{r}\text { Zimbabwe } \\
\text { III } \\
\end{array}$ & & $\begin{array}{r}0.0005 \\
(0.0002) \\
\end{array}$ & $\begin{array}{r}0.8718 \\
(0.0042) \\
\end{array}$ & $\begin{array}{r}0.0000 \\
(0.0000) \\
\end{array}$ & $\begin{array}{r}0.1561 \\
(0.0373) \\
\end{array}$ \\
\hline
\end{tabular}

a Confirmed not the global minimum. ${ }^{b}$ Failed to converge. ${ }^{c}$ Standard errors not available. ${ }^{d}$ Local optima suspected. 
Figure la Argentina

volatility, regular models

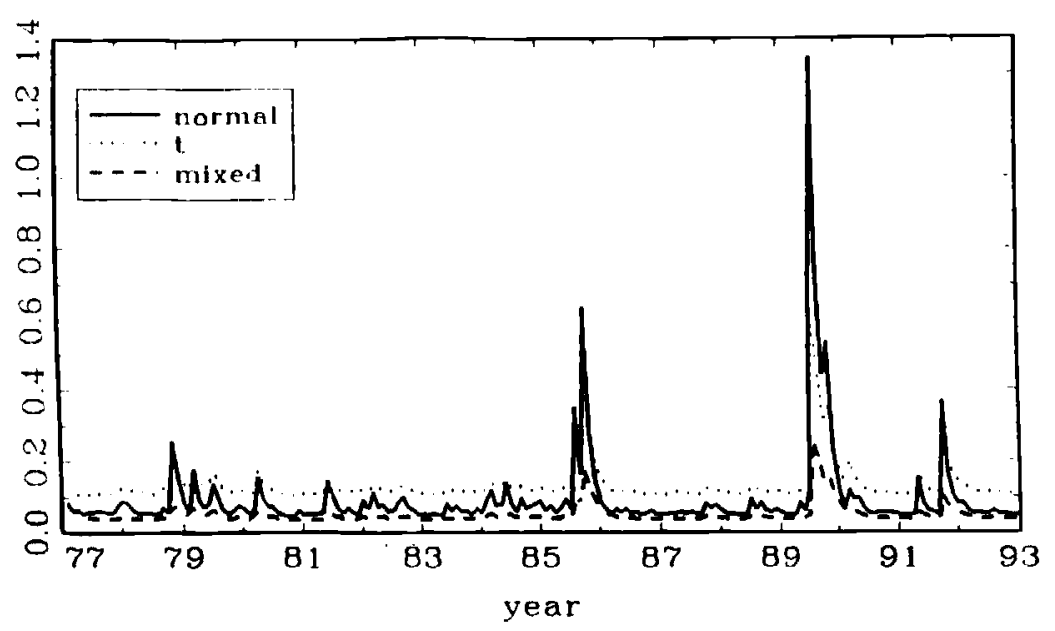

Figure 1c. Chile

volatility, regular models

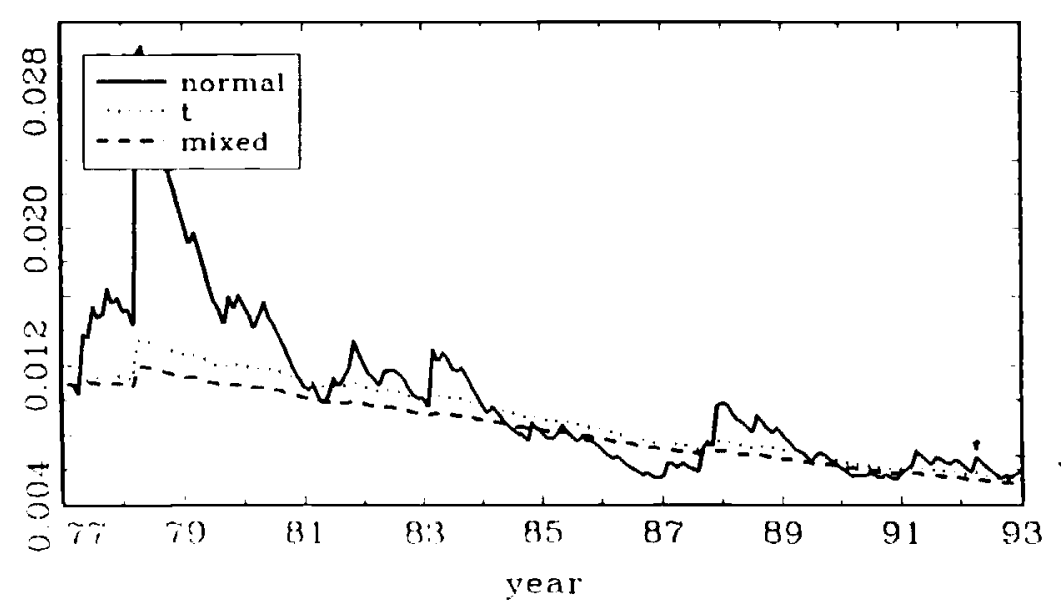

Figure 1b. Brazil

volatility, regular models

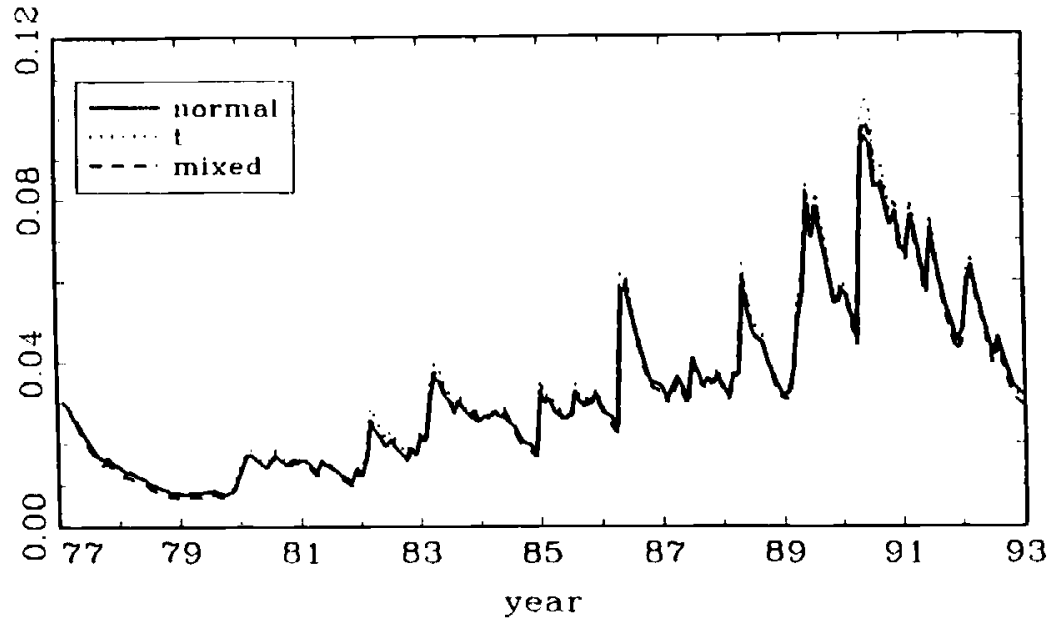

Figure 1d. Colombia volatility, regular models

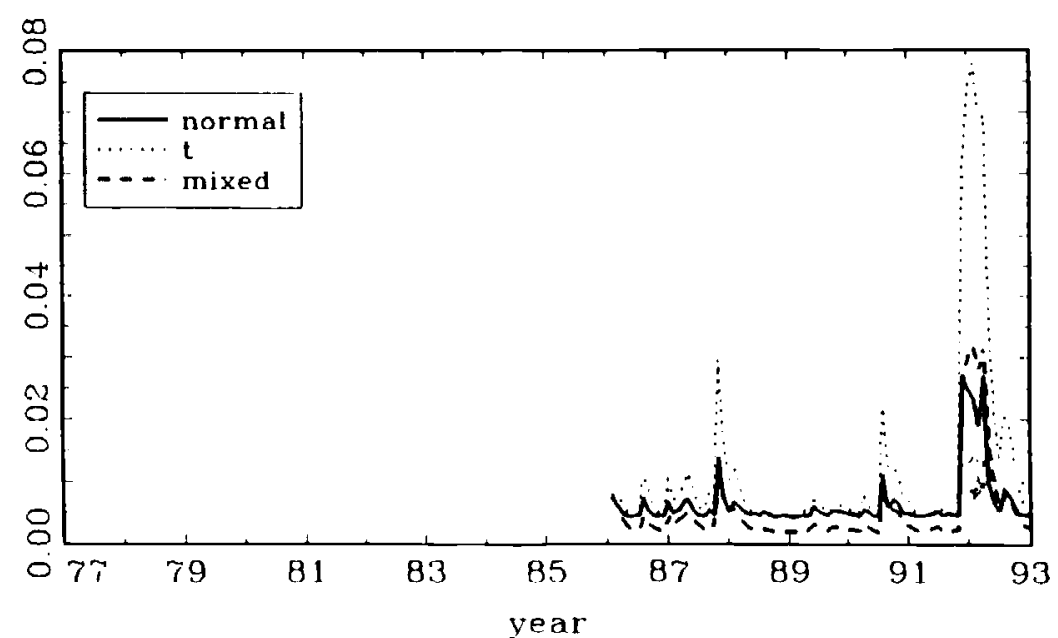


Figure 1e. Greece

volatility. regular models

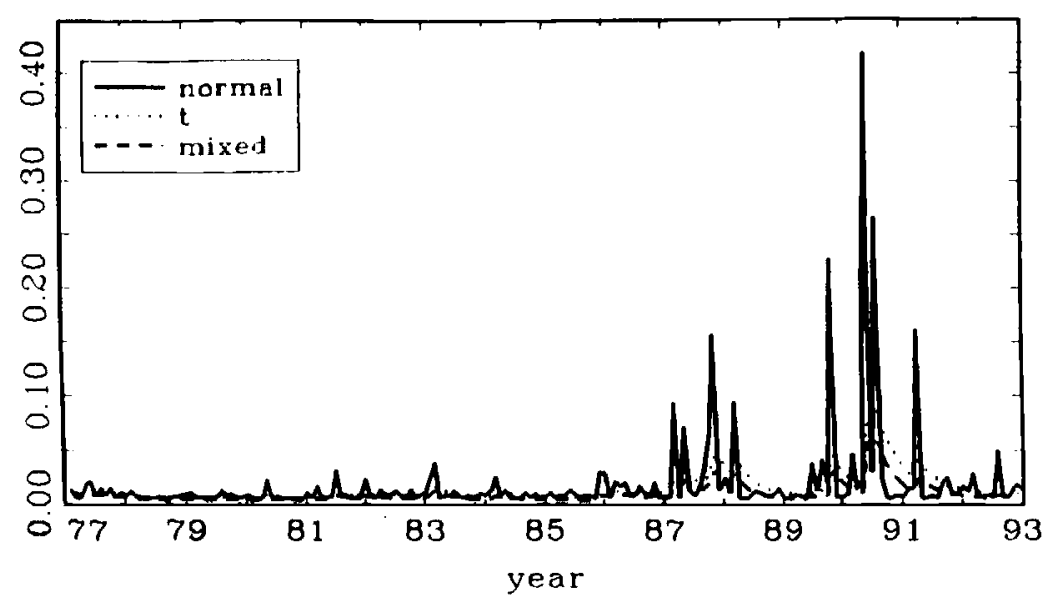

Figure 1g. Indonesia volatility. regular models

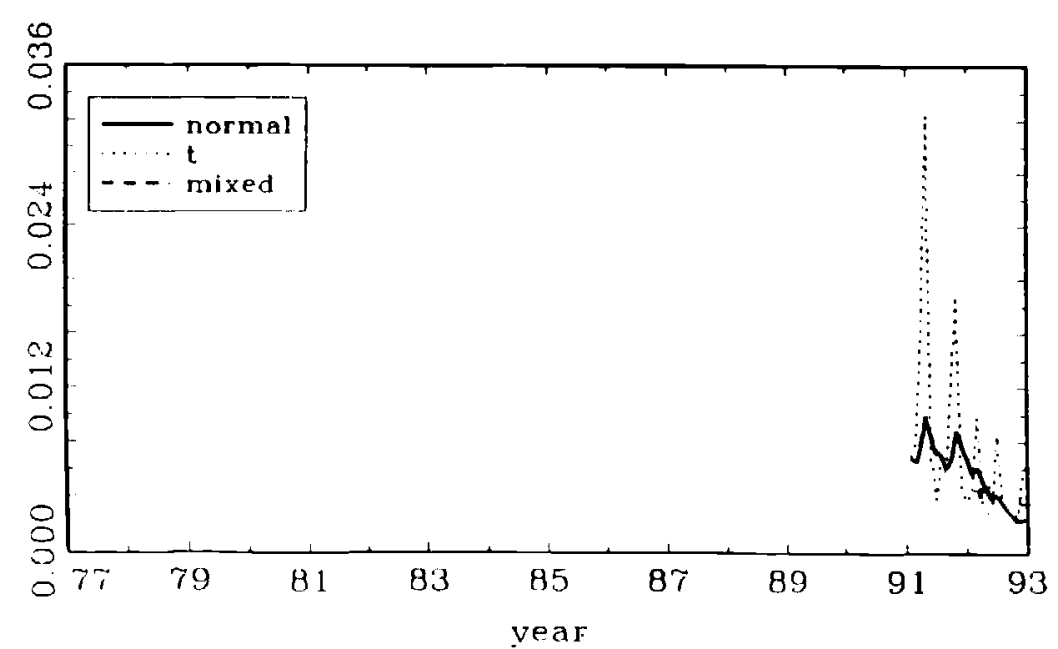

Figure 1f India volatility, regular models

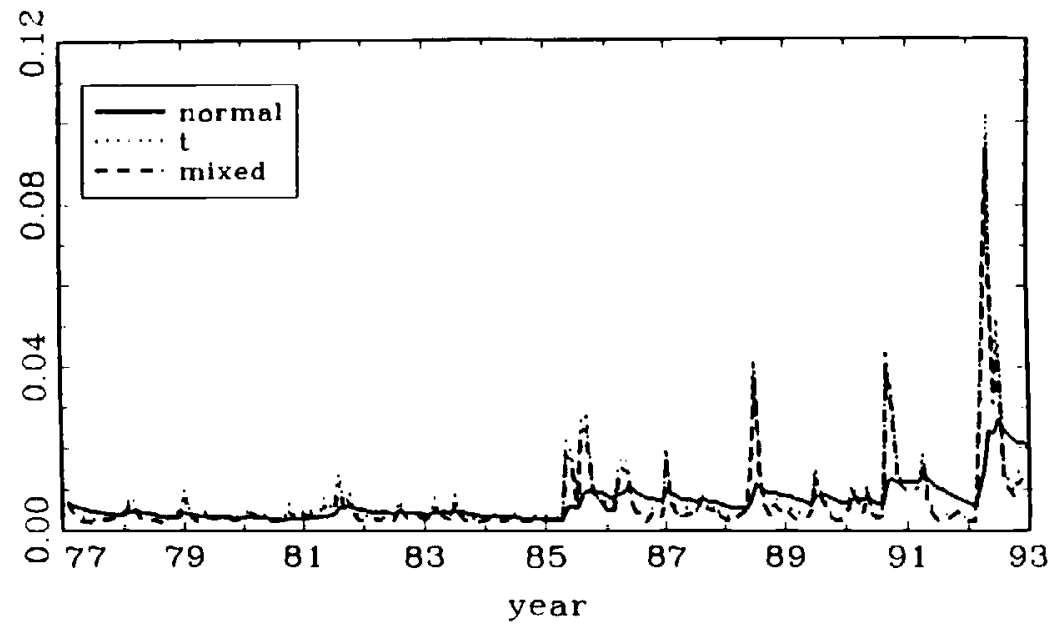

Figure 1h. Jordan volatility, regular models

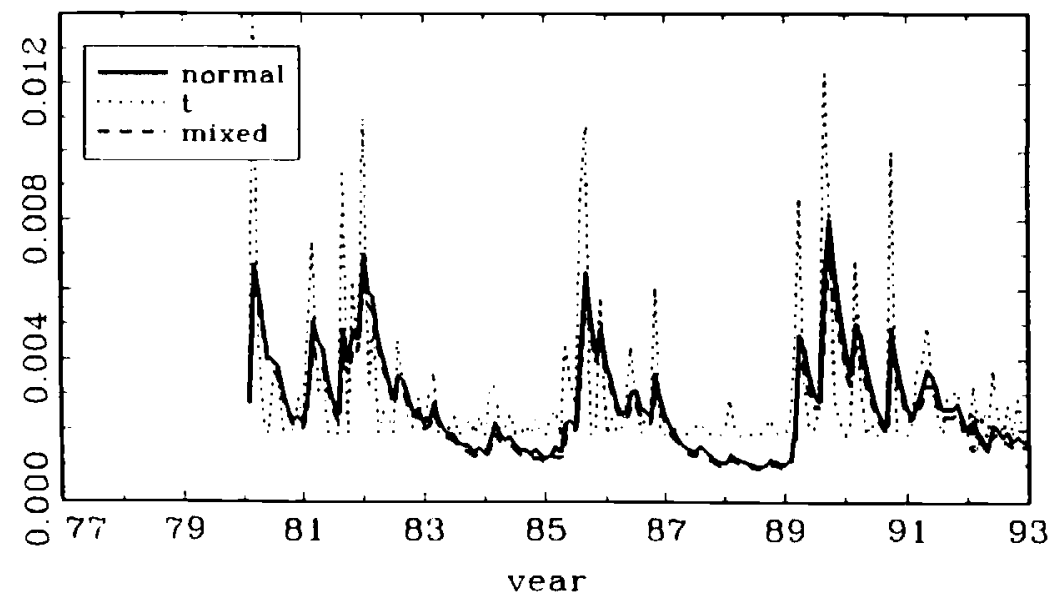


Figure 1 i korea

volatility, regular models

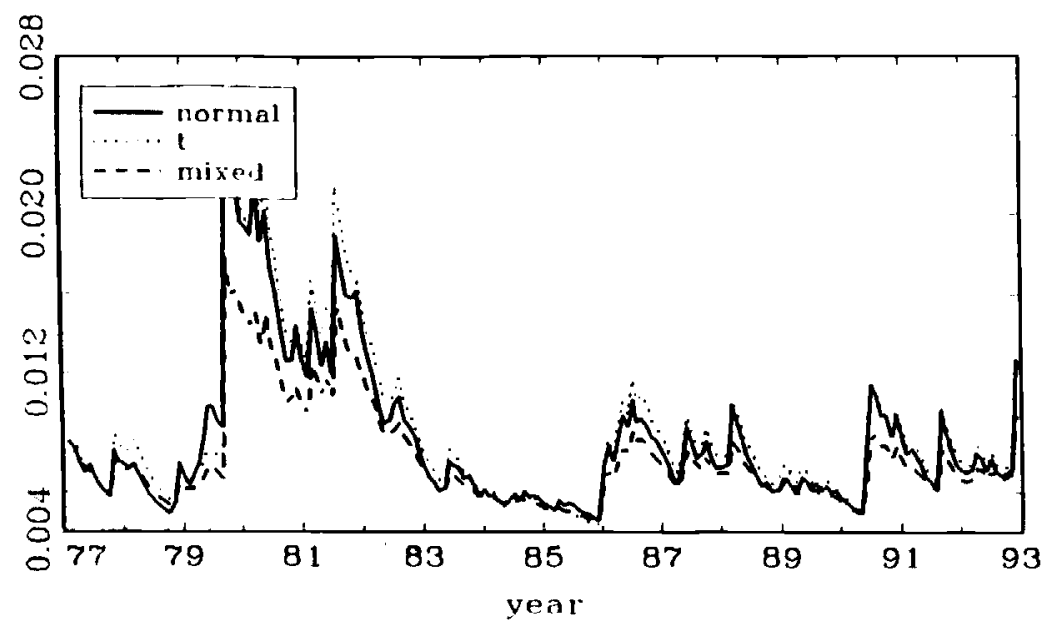

Figure 1k. Mexico

volatility. regular models

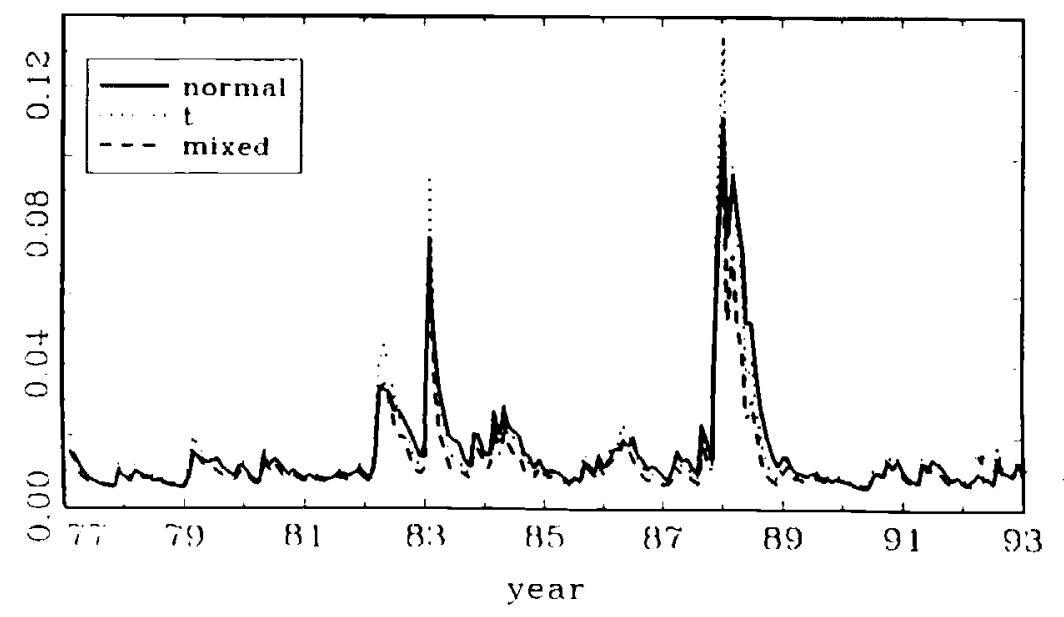

Piglure 1j. Malavsia volatility. regular nodels

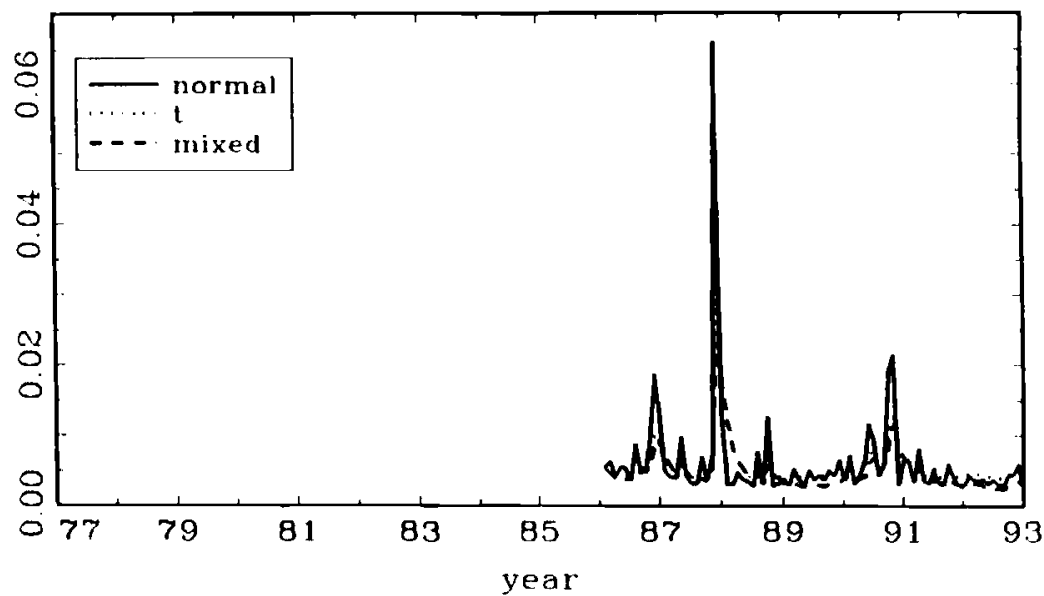

Figure 11. Nigeria

volatility, regular models

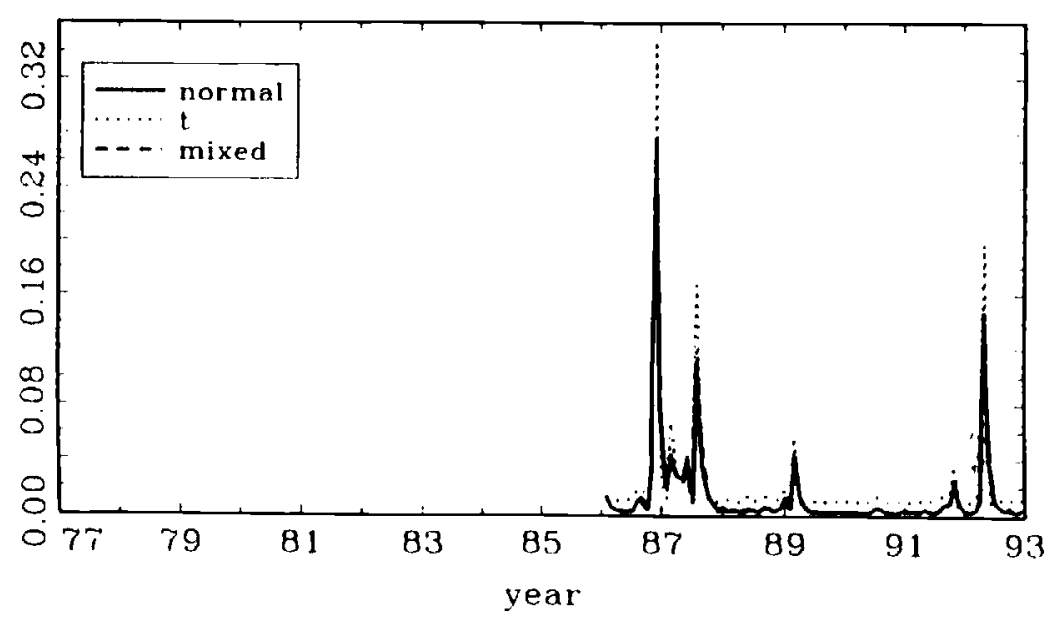


Figure $1 \mathrm{~m}$. Pakistan

volatility, regular models

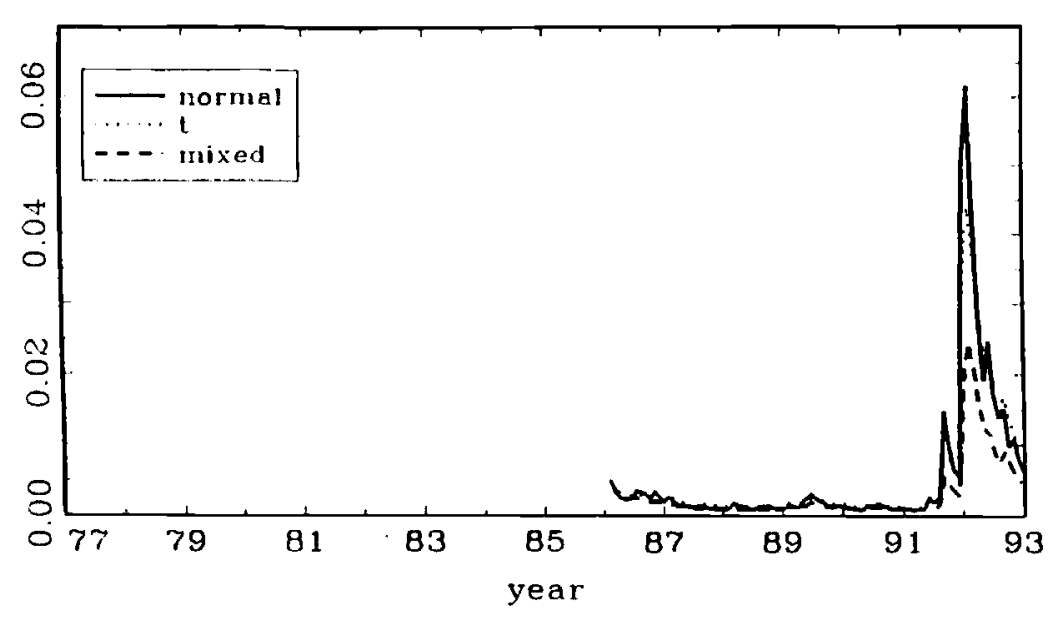

Figure 10. Portugal

volatility, regular models

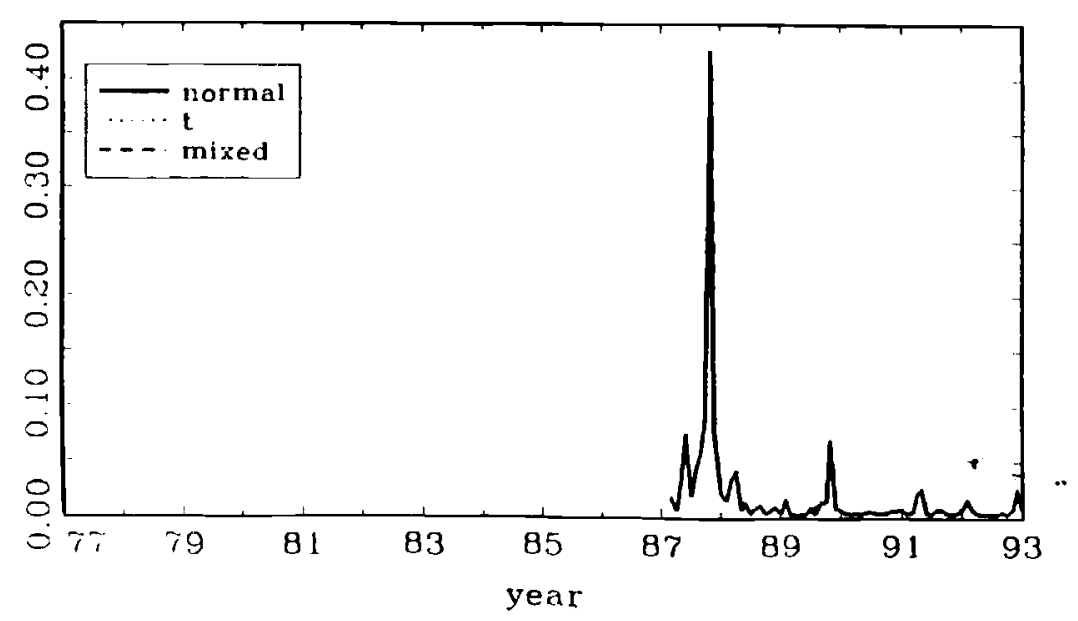

Figure 1n Philippines

volatility, regular models

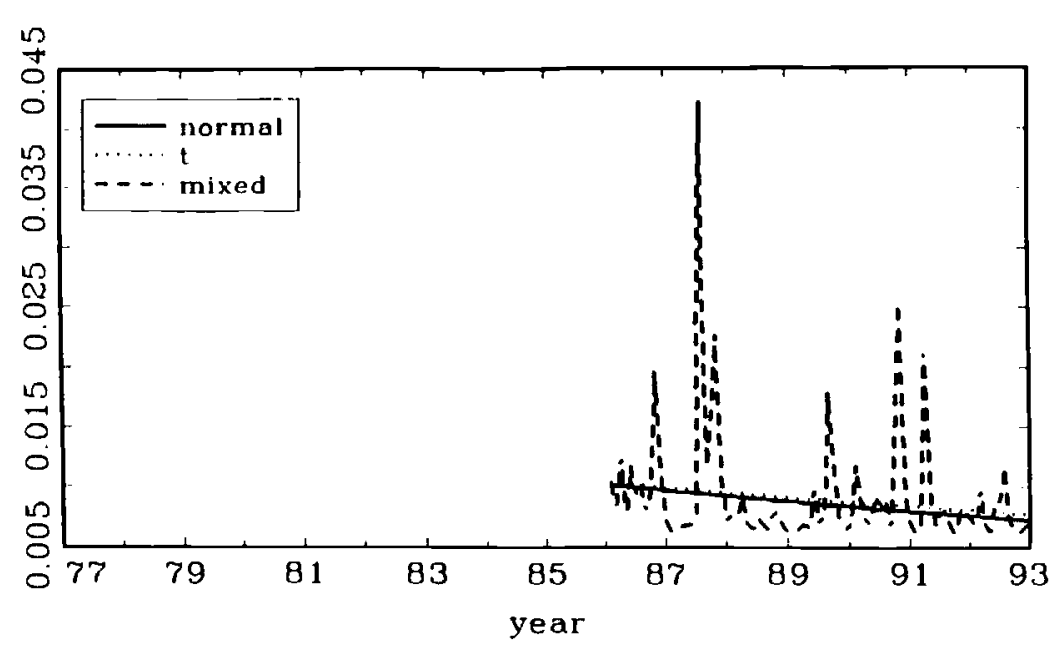

Figure 1p. Taiwan volatility, regular models

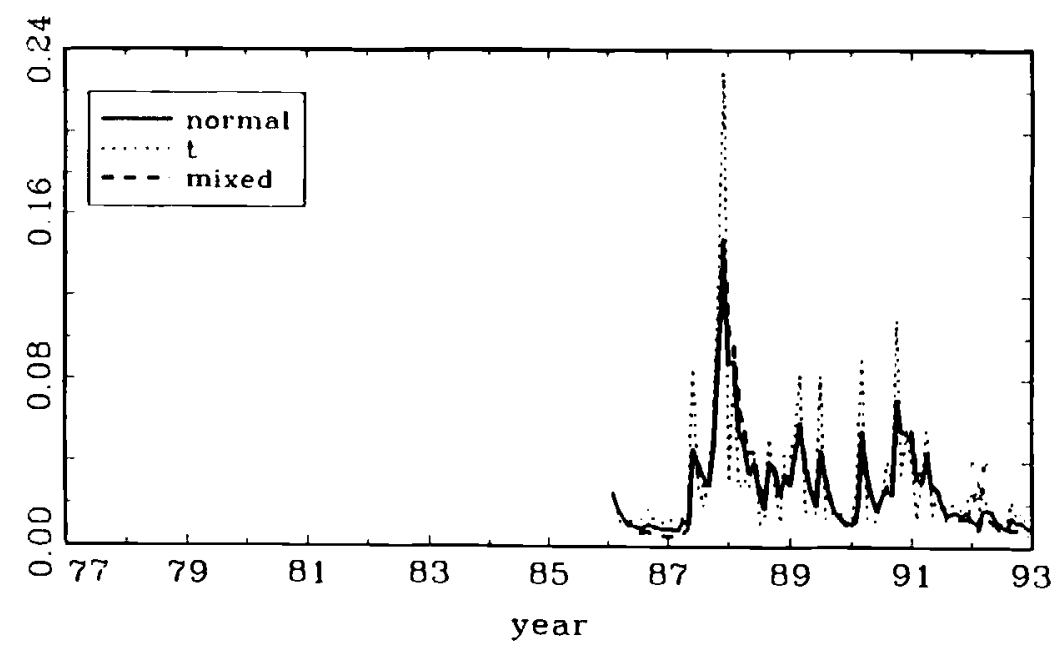


Figure 1q. Thailand volatility, regular models

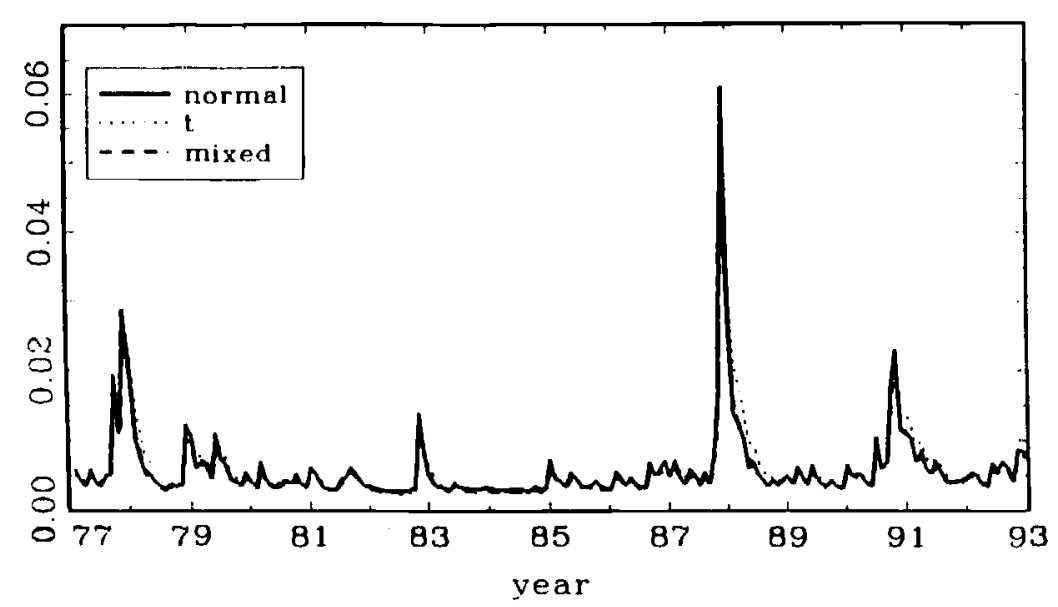

Figure 1s. Venezuela volatility. regular models

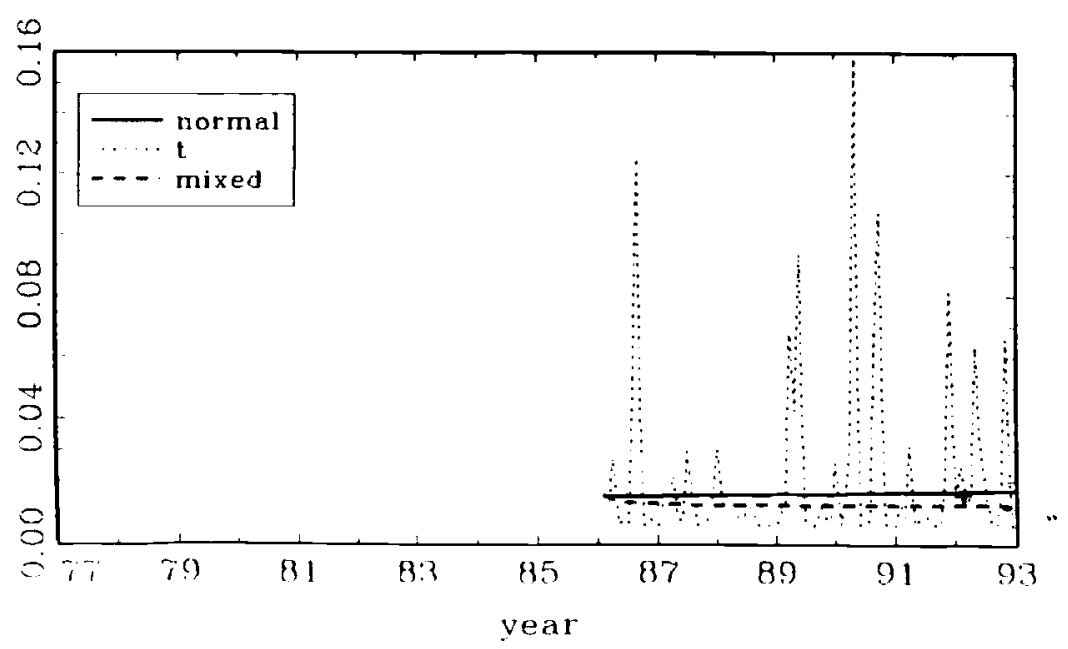

Figure 1r. Turkey volatility, regular models

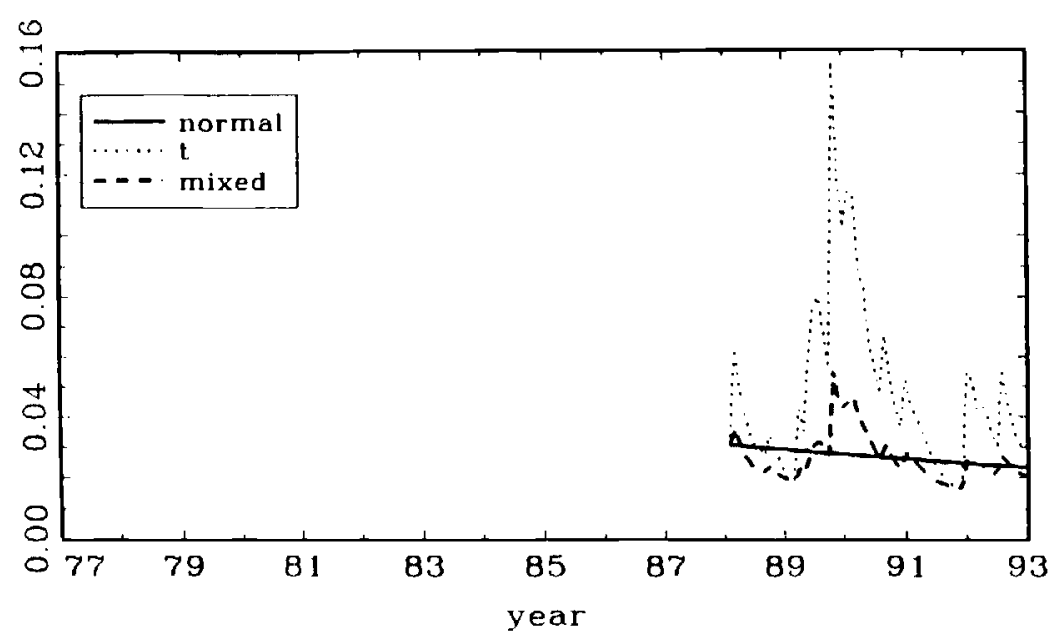

Figure 1t. Zimbabwe volatility, regular models

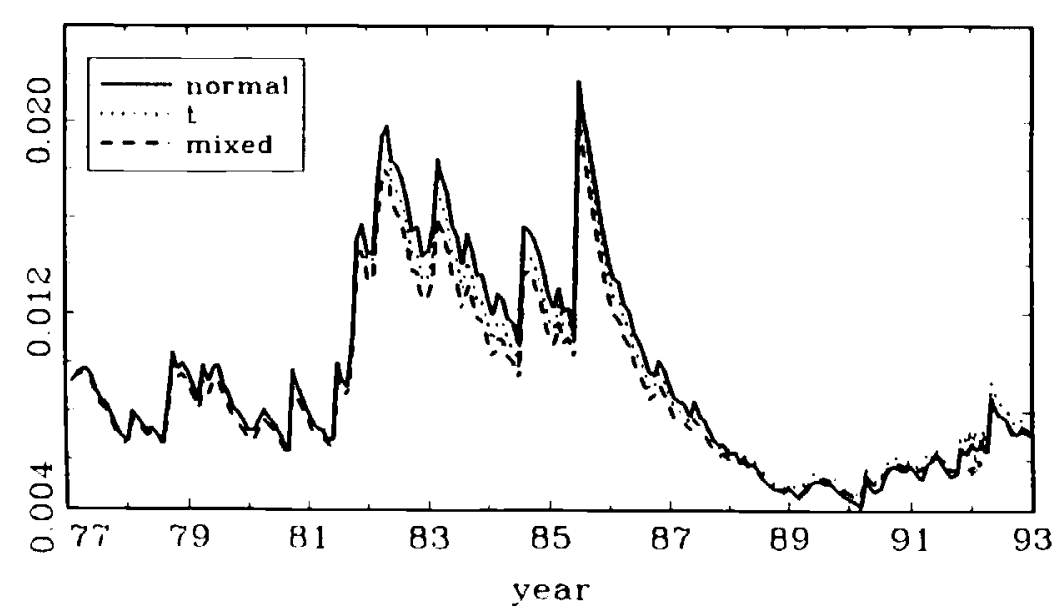


Figure 2a Argentina

volatility, asymmetric models

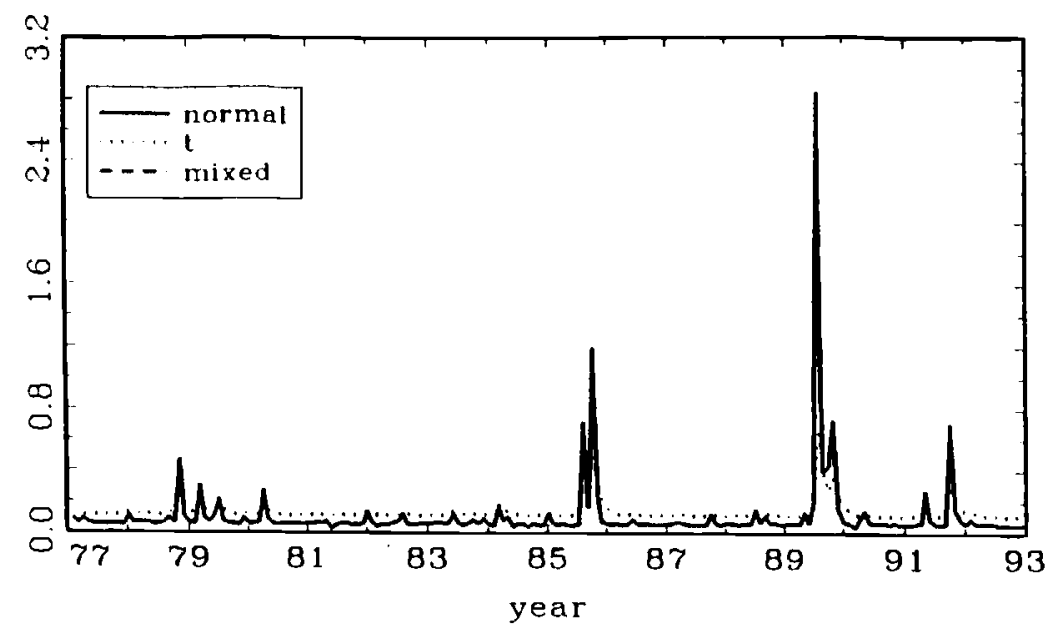

Figure 2c. Chile

volatility, asymmetric models

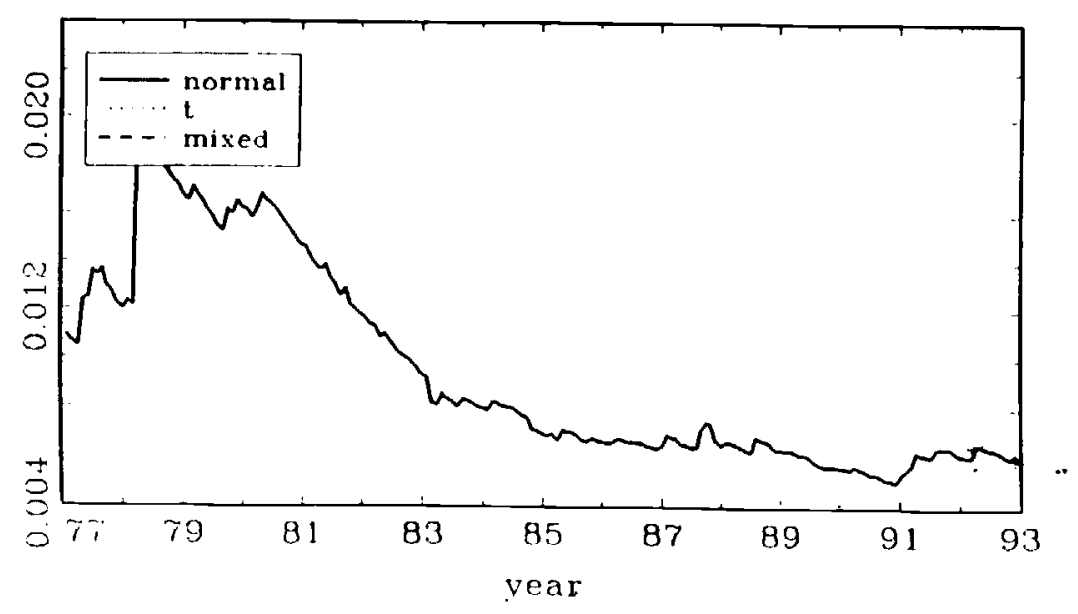

Pigure eb. Brazil

volutility, asymmetric models

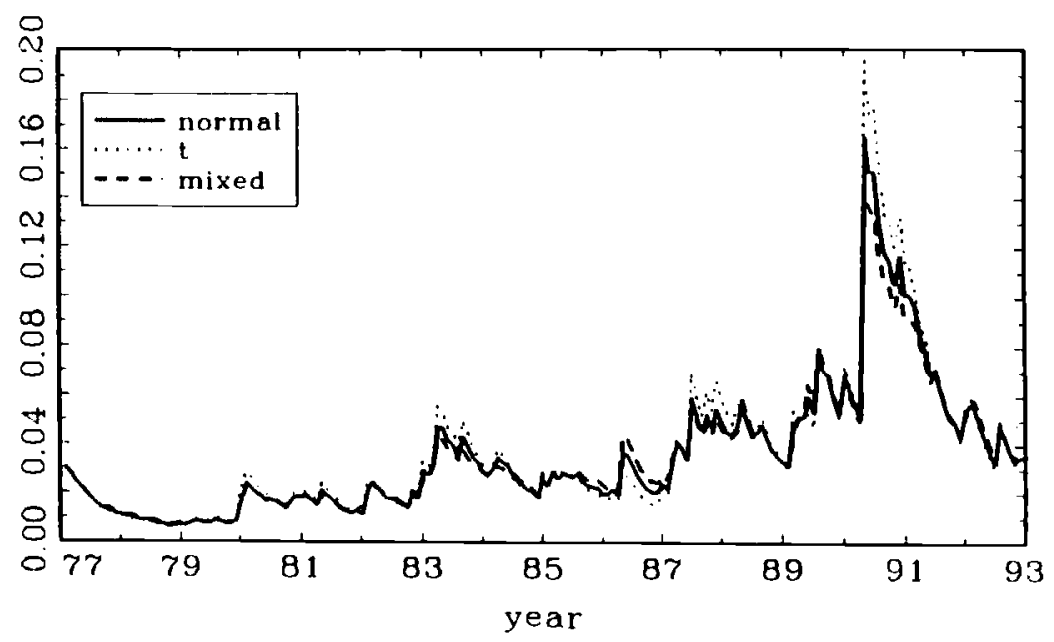

Figure 2d. Colombia

volatility, asymmetric models

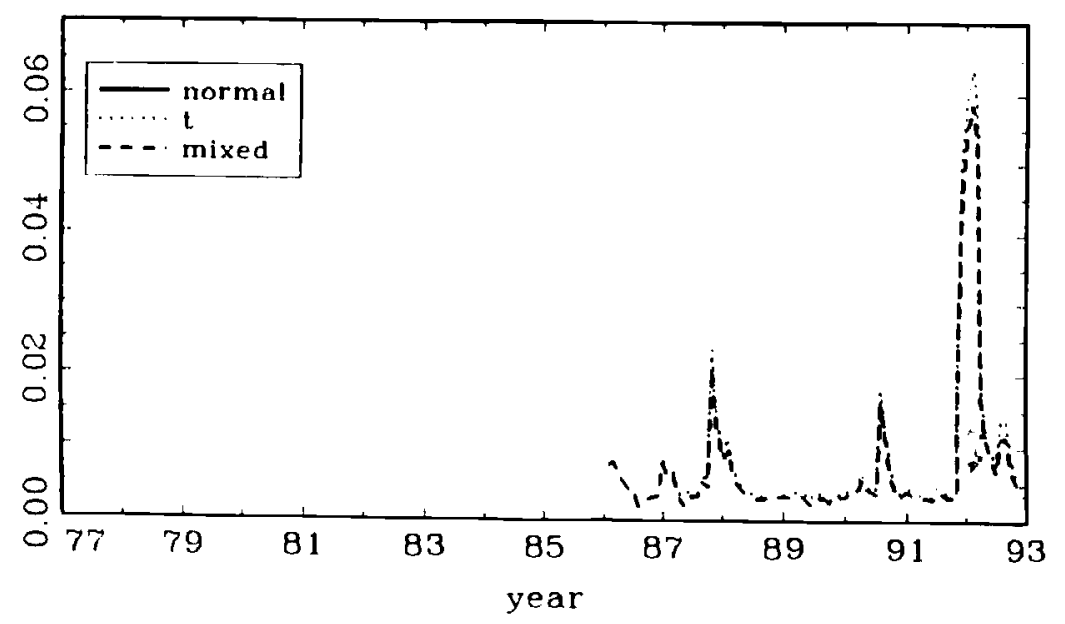



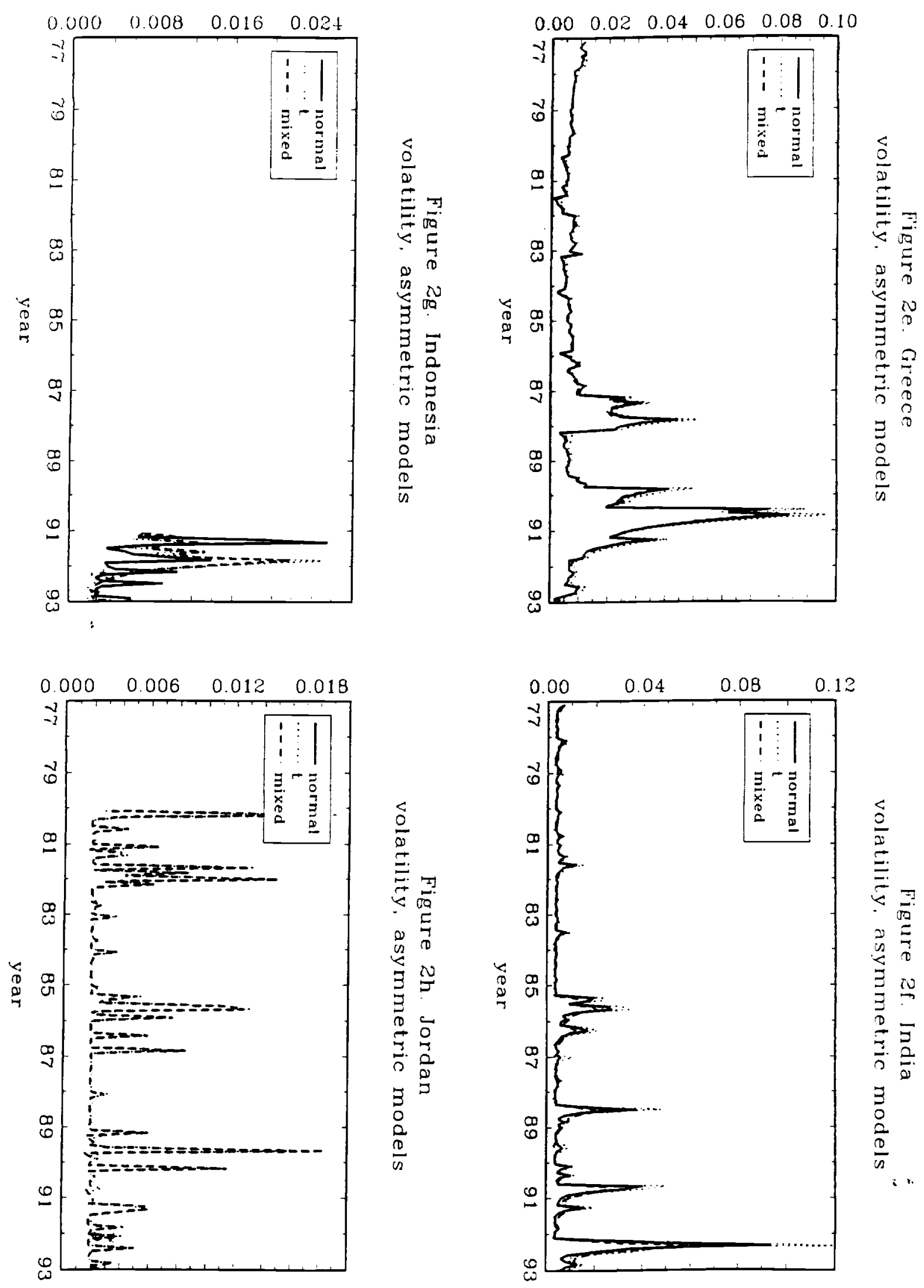
ligure 2 i korea

volatility, asymmetric models

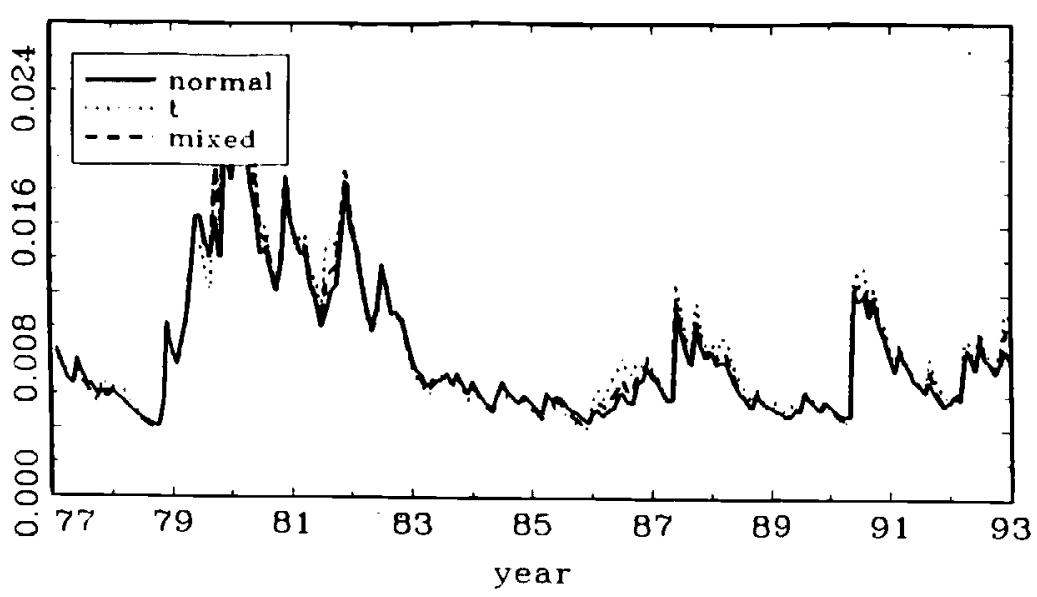

Figure 2k. Mexico

volatility, asymmetric models

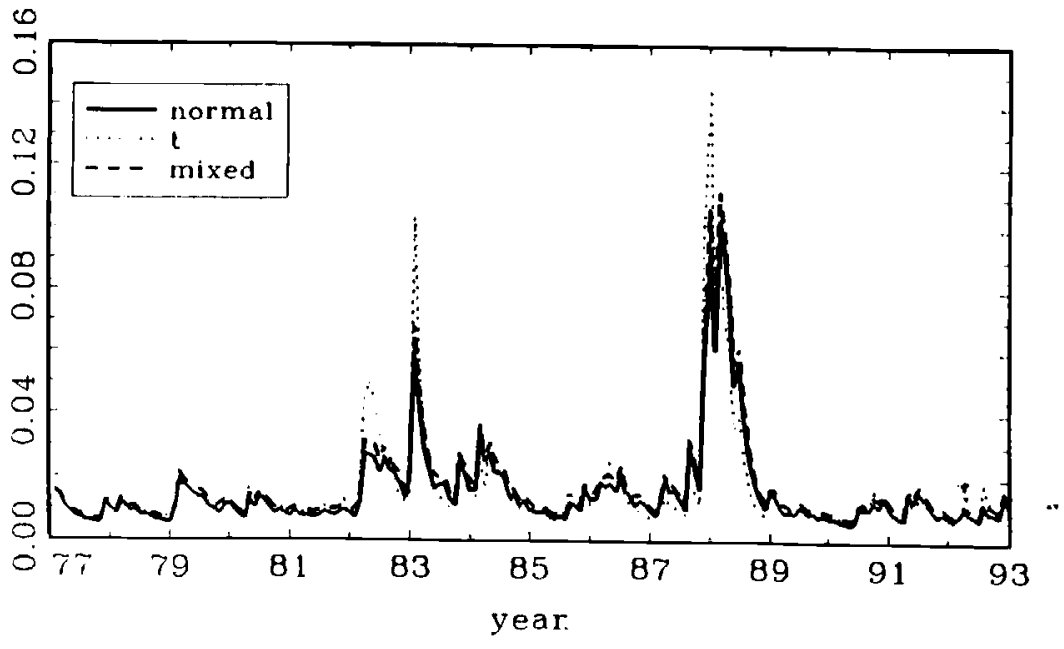

Finure 2j. Malaysia

volilility, asymmetric models

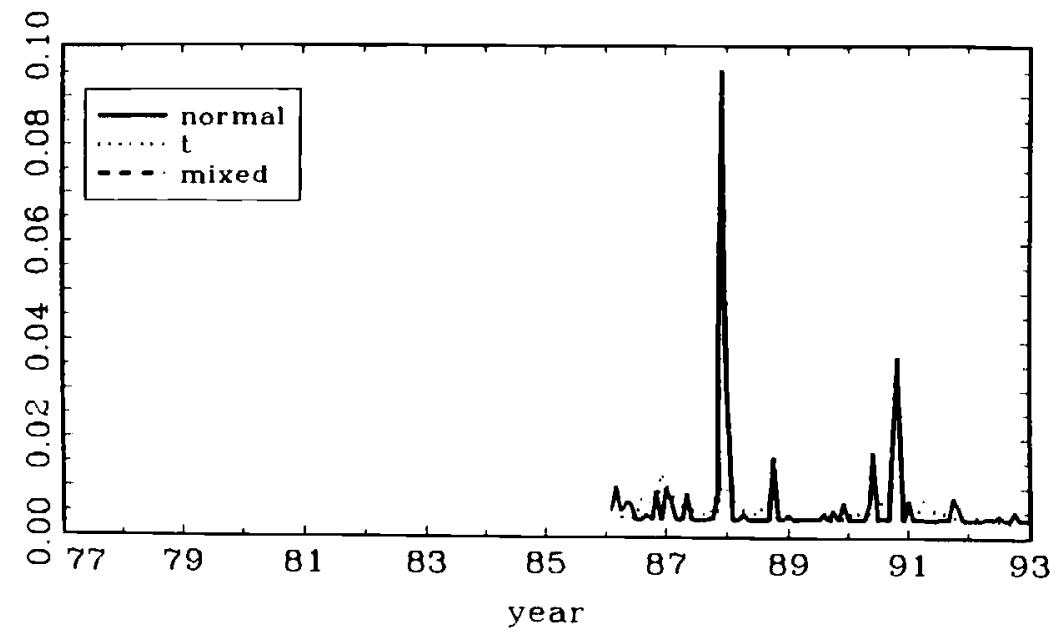

Figure 2l. Nigeria

volatility, asymmetric models

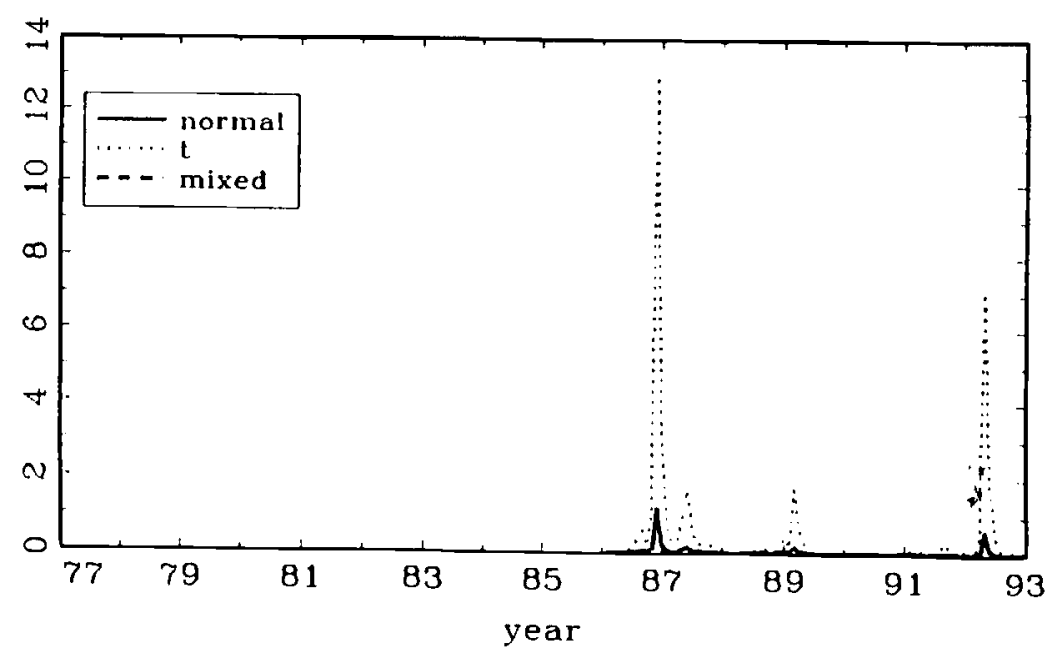


Figure $2 \mathrm{~m}$. Pakistan

volatility, asymmetric models

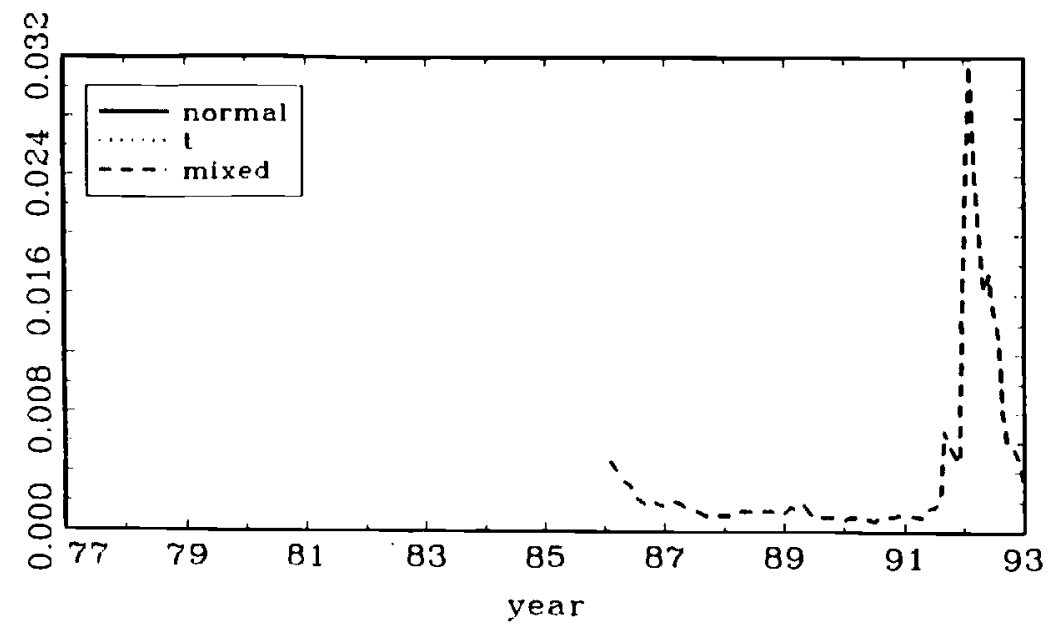

Figure 2o. Portugal

volatility, asymmetric models

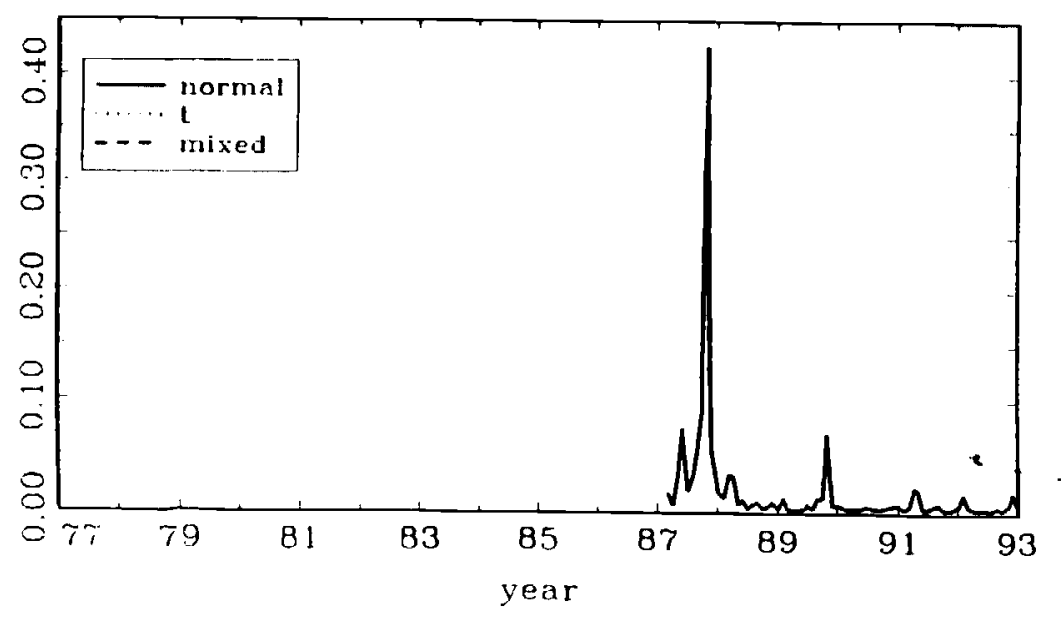

Figure 2n. Philippines

volatility, asymmetric models

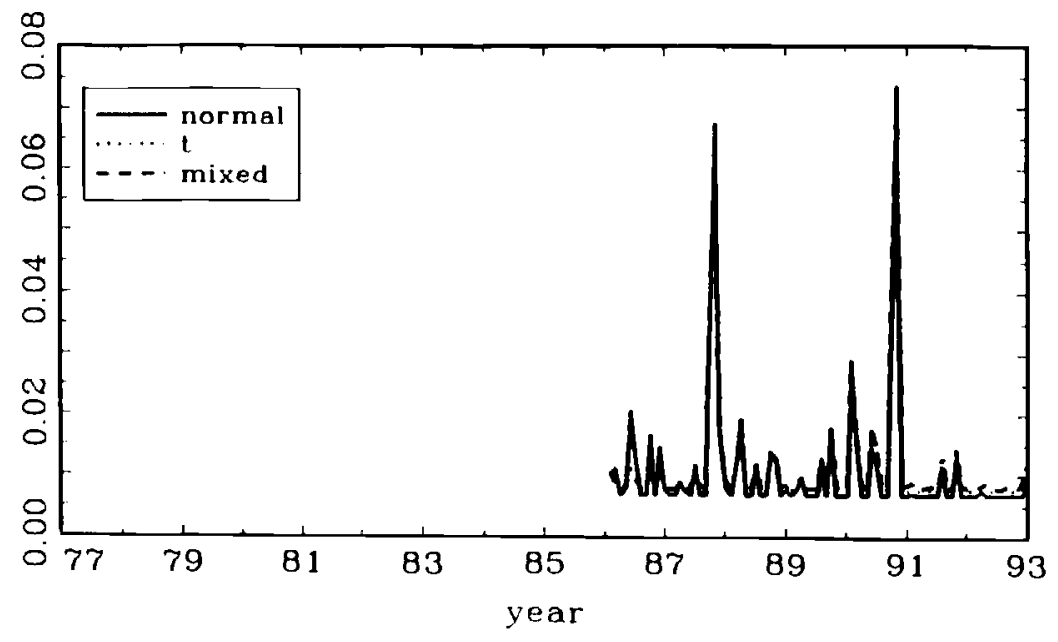

Figure 2p. Taiwan

volatility, asymmetric models

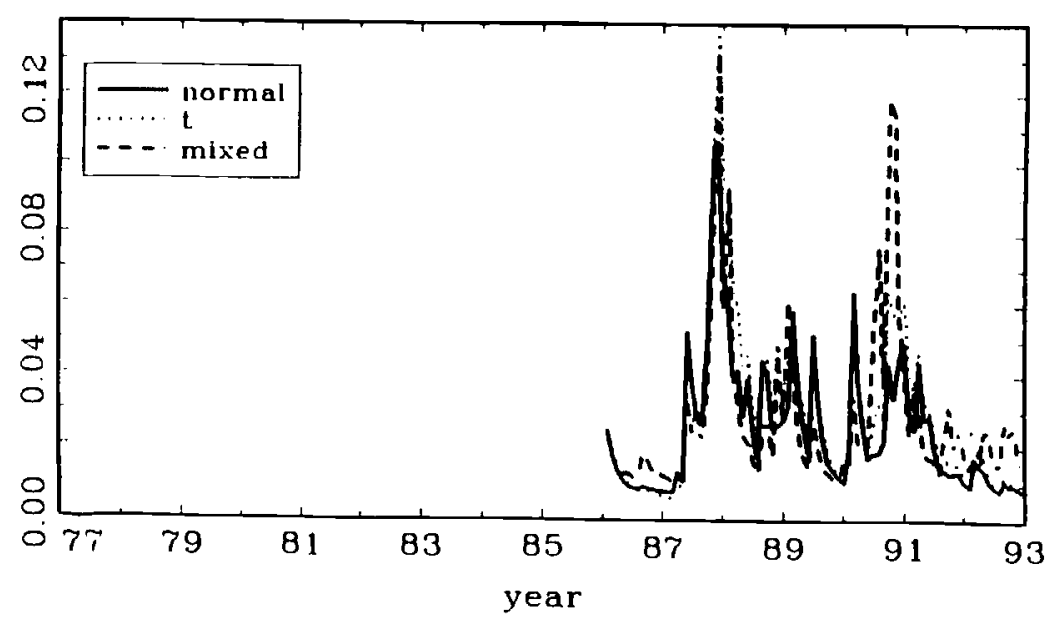


Figure 2q. 'Thailand volatility, asymmetric models

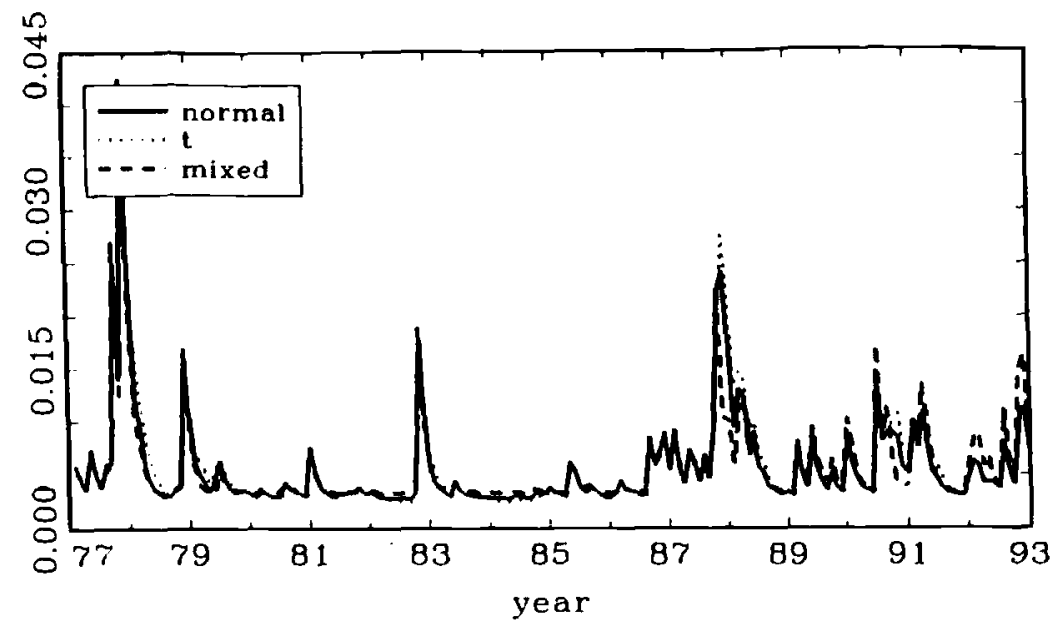

Figure 2s. Venezuela volatility, asymmetric models

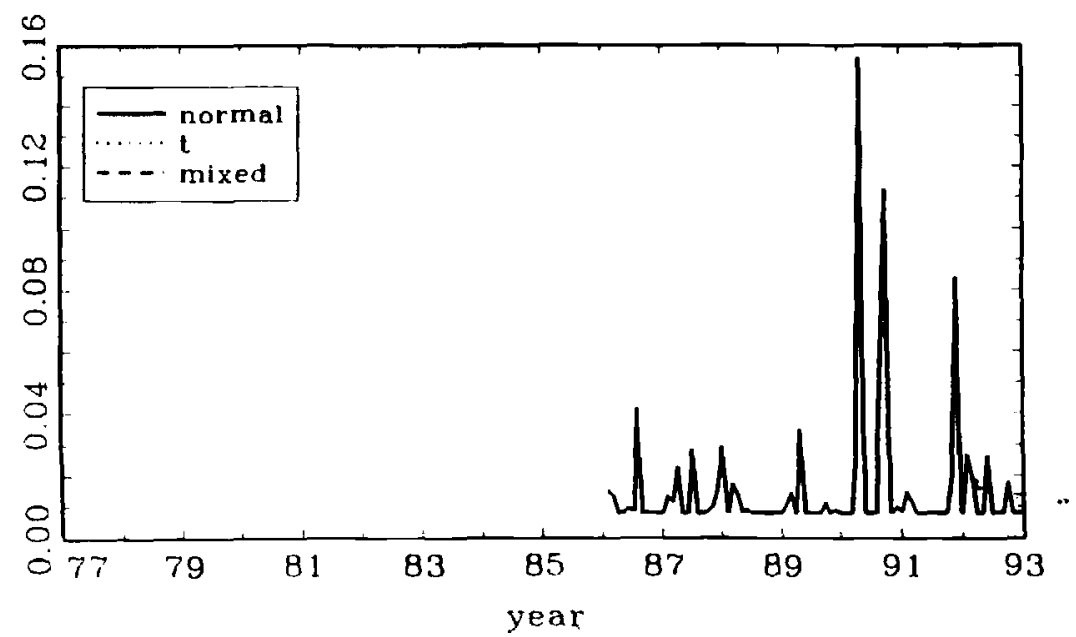

Figure 2t. Zimbabwe volatility, asymmetric models

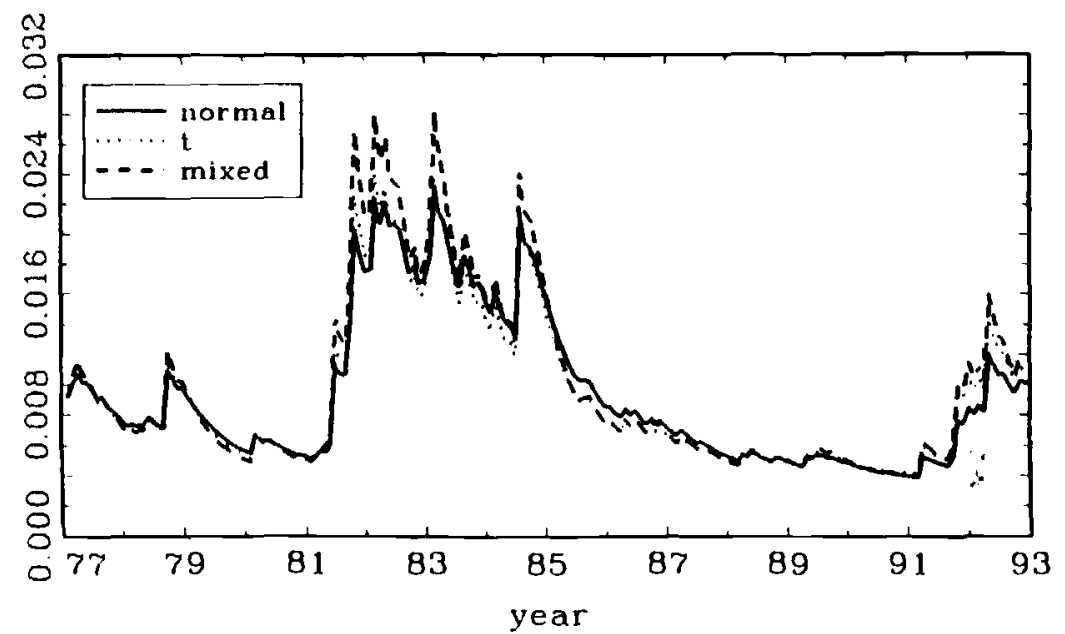

